\title{
NON-CONSENSUAL, DECEITFUL AND MISATTRIBUTED PATERNITY
}

\author{
Zoë Lawton \\ A dissertation submitted to Victoria University of Wellington \\ to fulfill the requirements of a Master of Laws
}

FACULTY OF LAW

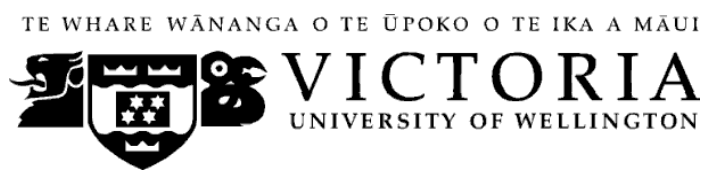

2013 



\section{Acknowledgements}

This dissertation would not have been possible without the incredible advice, encouragement, and support from my supervisor, Professor Bill Atkin. When Bill agreed to supervise me for an undergraduate research project I was a slightly lost student, but through that experience I discovered that family law research was exactly what I wanted to do. Masters followed and I'm now working as Research Counsel to the Principal Family Court Judge. I could not have asked for a better mentor in Bill and I am so appreciative of all the time he has given me over the years.

I would also like to thank my family, friends, and colleagues who have supported me, taken the time to debate various issues with me, and shared their opinions (and very interesting anecdotes). Their interest in my research and contributions have made the process of researching and writing this dissertation an awesome experience. 



\begin{abstract}
This dissertation is about three types of paternity: non-consensual, deceitful and misattributed paternity. It is argued that these types of paternity are a modern reality that result in serious practical and legal consequences for all parties involved, but particularly for the father and child. They do not sit comfortably within the current legal framework on paternity which is too rigid, unclear or outdated to resolve issues that arise, and perhaps result in inequitable outcomes. In the light of this, several recommendations are provided to resolve these issues, most taking the form of statutory amendments.

While tort actions have traditionally often been commercial in nature, recent developments demonstrate that certain conduct taking place within a domestic context can also attract liability. For example, deceit and negligent misstatement claims to recover "damage" caused by misattributed paternity have had varying degrees of success in England, Australia and Canada. A successful claim could potentially be made in New Zealand, although in certain limited circumstances, claims should be barred on public policy grounds.
\end{abstract}

\title{
Word length
}

The text of this paper (excluding abstract, table of contents, footnotes and bibliography) comprises approximately 35,000 words.

\section{Subjects and Topics}

Family Law - Paternity

Family Law - Legal Parenthood

Family Law - Child Support

Medical Law - Assisted Human Reproductive Technology

Criminal Law - Sexual Offences

Torts - Deceit

Torts - Negligent Misstatement 



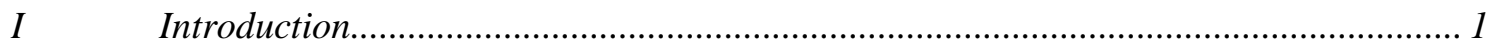

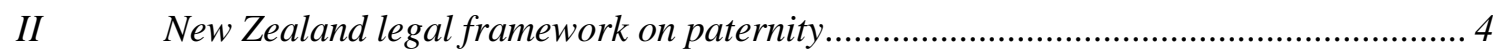

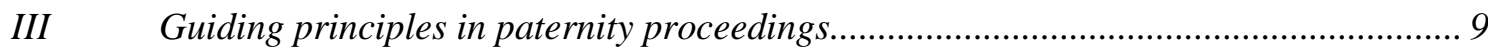

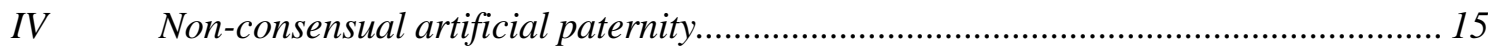

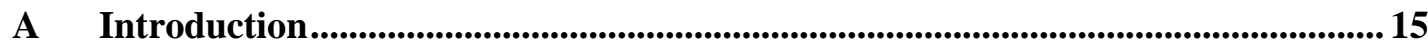

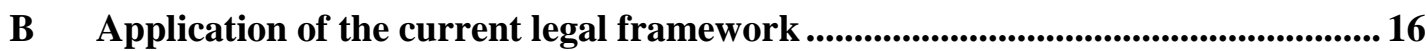

C The main principles supporting the current legal framework................................. 19

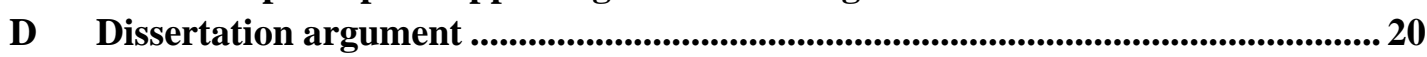

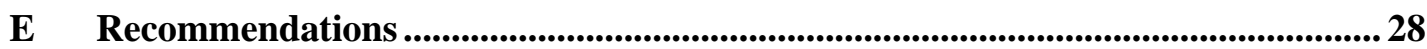

$V \quad$ Non-consensual natural paternity and deceitful natural paternity ................................. 30

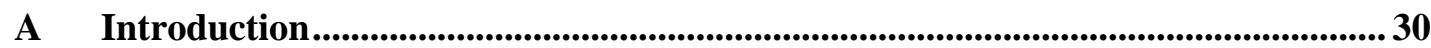

B Application of the current legal framework ...............................................................31

C The main principles supporting the current legal framework...................................33

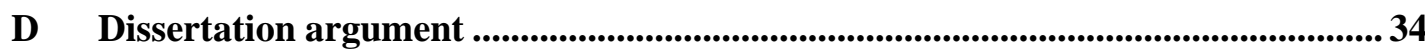

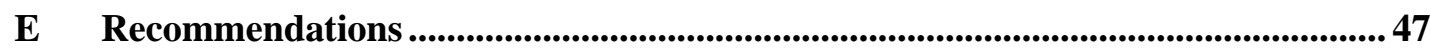

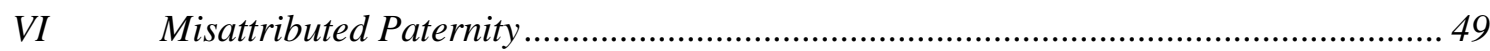

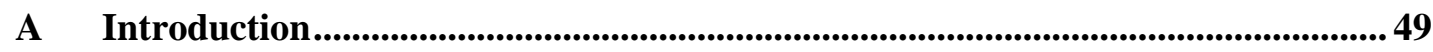

B Application of the current legal framework ...........................................................550

C The main principles supporting the current legal framework...............................55

D Dissertation argument .............................................................................................. 56

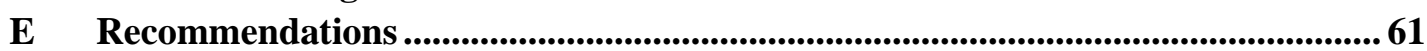

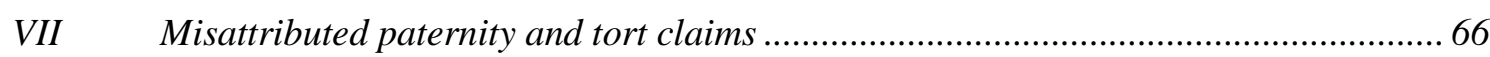

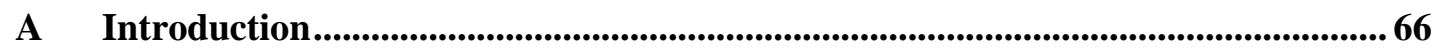

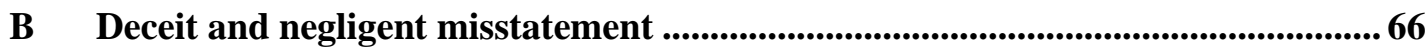

C Proving the elements of deceit................................................................................68

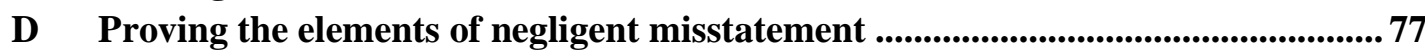

E Conclusions on proving the elements ................................................................79

F Application of deceit and negligent misstatement ...............................................79

G Tort claims for non-consensual and deceitful paternity .......................................8 87

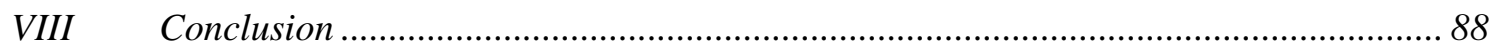





\section{Introduction}

\section{A Dissertation topic}

Parenthood is a complex area of law and of life. Ideally, both parents knowingly and consensually conceive a child together, either through natural or artificial conception, ${ }^{1}$ as this can simplify both the practical and legal consequences for the mother, father and the child. However, in reality there are many complex scenarios in which a child may be conceived that can result in a practical, legal, and moral minefield. Some of the most complex scenarios are those where the paternity of a child is non-consensual, deceitful, or misattributed as they raise complex issues for all the parties involved. This dissertation explores these scenarios and the various issues that arise.

In simple terms, this dissertation analyses four types of paternity:

(1) non-consensual artificial paternity;

(2) non-consensual natural paternity;

(3) deceitful natural paternity; and

(4) misattributed paternity.

Non-consensual artificial paternity results from the use of a male's semen (or embryos created using his semen) by a female in an assisted human reproductive procedure (AHR procedure) without his consent to conceive a child. This type of paternity can occur when a couple agree to store semen samples or embryos for future use but then separate, and after the separation the female party goes ahead with an AHR procedure using the samples without the knowledge of her former partner and conceives a child. Alternatively, the couple may have begun fertility treatment using the samples and separate in the course of treatment, and after the separation the female party continues treatment without the knowledge of her former partner and conceives a child.

Non-consensual natural paternity results from the unplanned conception of a child after consensual sexual intercourse. The conception of the child may have resulted from a lack of contraception, faulty contraception or simple miscommunication. Similarly, deceitful natural paternity results from consensual sexual intercourse although it is a deliberate deceitful act by the child's biological mother that resulted in the conception of the child. She may have lied about her use of the contraceptive pill, pricked the condom, lied about infertility, or collected discarded semen (for example out of a used condom) and inseminated it without the knowledge or consent of the biological father. Similarly, semen could collected in the course of oral sex and be inseminated without the knowledge or consent of the biological father.

\footnotetext{
${ }^{1}$ Natural conception means conception resulting from sexual intercourse and artificial conception means conception resulting from an AHR procedure.
} 
Finally, misattributed paternity results from the incorrect identification of the child's biological father by the child's biological mother either mistakenly, recklessly or intentionally. In scenarios involving misattributed paternity, the non-biological father and child are unaware of the fact they do not share a biological relationship until such a time when the true paternity of the child is discovered or revealed. ${ }^{2}$

\section{B Dissertation statement}

It is argued that non-consensual, deceitful and misattributed paternity is a modern reality that has serious practical and legal consequences for all parties involved, but particularly for the father and the child. These types of paternity do not sit comfortably within the current legal framework on paternity which is too rigid, unclear or outdated to resolve issues that arise, and perhaps result in inequitable outcomes. Therefore, changes need to be made to this legal framework.

\section{Structure of this dissertation}

Firstly, the current legal framework on paternity in New Zealand is outlined and the legal principles used to resolve paternity related issues are identified. The four different types of paternity outlined above are then analysed, using the same five step analytical framework. ${ }^{3}$

(1) At the start of each chapter, the type of paternity to be analysed is clearly defined.

(2) In order to put each type of paternity into context, hypothetical scenarios containing a range of fact patterns are provided. Each hypothetical scenario is analysed using the current legal framework to determine whether, upon the birth of the child, the male in each scenario becomes the legal father of the child, or in the case of misattributed paternity, should remain the legal father of the child.

(3) The main principles reflected in the current legal framework and resulting legal outcome are then identified.

(4) Consideration is then given to whether the current legal framework and resulting legal outcome are satisfactory. Arguments are made out based on various principles. New Zealand legislation and case law is drawn upon, although supplementary legislation and case law from other countries is used where there is a lack of New Zealand authority on the relevant issue.

(5) Finally, conclusions are drawn and recommendations made.

\footnotetext{
${ }^{2}$ Misattributed paternity can also result where babies are accidentally or negligently swapped at birth. However, these scenarios are not discussed in this dissertation.

${ }^{3}$ Non-consensual natural paternity and deceitful paternity are analysed concurrently within the same chapter as similar issues arise in regards to both types of paternity.
} 
This dissertation then considers deceit and negligent misstatement claims in the context of misattributed paternity. The central issue in this chapter is whether a male can bring a successful claim in New Zealand against the mother of the child to claim "damage" caused as a result of being incorrectly identified as the father of the child. Claims of this nature have emerged in other countries within the common law jurisdictions, namely, England, Australia and Canada, with varying degrees of success. While such a claim has not yet come before a New Zealand court, it is arguably inevitable that one will arise in future. Therefore, this is an important issue that needs to be addressed.

While non-consensual and deceitful paternity could also attract tort liability, this dissertation concentrates solely on tort liability for misattributed paternity as no deceit or negligent misstatement claims for non-consensual or deceitful paternity have emerged in the common law jurisdictions. However, examples of potential tort claims that could arise are briefly discussed.

\section{Purpose of this dissertation}

This dissertation has both a practical and academic purpose. Firstly, to provide clear practical recommendations in the form of statutory amendments or new statutory provisions. The recommendations are based on legal analysis of the current law and are tested against a set of legal principles. They could be the subject of further research or recommendation by the Law Commission, considered or implemented in policies developed by the Ministry of Justice, Ministry of Social Development and Inland Revenue, or used by a Member of Parliament to bring about legislative reform.

While this dissertation aims to be practical, it is not based on the assumption that it provides all the answers to the many complex legal issues that are discussed. Further research into this area of the law is needed as many of the issues analysed in this dissertation have not been explored in New Zealand academic literature. This dissertation aims to add to and hopefully generate further academic debate and research in New Zealand and overseas. 


\section{New Zealand legal framework on paternity}

This dissertation draws primarily on five Acts that contain provisions which determine paternity or relate to various aspects of paternity, namely: the Status of Children Act 1969, the Family Proceedings Act 1980, the Care of Children Act 2004, the Child Support Act 1991 and the Human Assisted Reproductive Technology Act 2004. In addition, this dissertation draws on New Zealand case law that has interpreted and applied various provisions of these Acts.

\section{A Fathers as legal parents and legal guardians}

Paternity means the state of being one's father. In law, a father can be both a legal parent of a child and a legal guardian of a child. ${ }^{4}$ The provisions in Part 1 of the Status of Children Act 1969 determine who are the legal parents of a naturally conceived child. ${ }^{5}$ Although there is no explicit statutory definition, the combined effect of the provisions in Part 1 is that the legal father of a child is his or her biological father. ${ }^{6}$

There are several powers, duties, rights and responsibilities that flow from the status of being a legal father in regards to intestacy, ${ }^{7}$ family protection, ${ }^{8}$ citizenship, ${ }^{9}$ and child support. ${ }^{10}$ Guardianship can also flow from the status of being a legal father. Usually, legal fathers are joint guardians with the child's mother unless she was neither married to or in a civil union with the child's father at any time during the period beginning with the conception of the child, and ending with the birth of the child, ${ }^{11}$ nor living with the child's father as a de facto partner at any time during that period. ${ }^{12}$ If a father is not a guardian by virtue of $\mathrm{s} 17$ he can become the child's legal guardian if he jointly registers his particulars as part of the child's birth information with the child's mother. ${ }^{13}$ If there is disagreement with the mother regarding guardianship, the father can apply to the Family Court to be appointed a guardian, ${ }^{14}$

\footnotetext{
${ }^{4}$ However, legal parenthood and legal guardianship are mutually exclusive. Accordingly, a father may solely be the child's legal parent or legal guardian.

${ }^{5}$ The only way this status can be altered in law is by the Adoption Act 1955, which reallocates legal parenthood further to a specified statutory scheme.

${ }^{6}$ Status of Children Act 1969, s 7, s 8, and s 10; Family Proceedings Act 1980, s 2 as amended by schedule 3 of the Care of Children Act 2004.

${ }^{7}$ Administration Act 1969, s 77.

${ }^{8}$ Family Protection Act 1955, s 3.

${ }^{9}$ Citizenship Act 1977, s 3.

${ }^{10}$ Child Support Act 1991, s 7.

${ }^{11}$ Care of Children Act 2004, s 17(2)(a).

${ }^{12}$ Section 17(2)(b).

${ }^{13}$ Section 18.

${ }^{14}$ Section 19.
} 
and the Court must appoint the father a guardian of the child unless to do so would be contrary to the child's welfare and best interests. ${ }^{15}$

\section{B Establishing fathers as legal parents}

Section 8 of the Status of Children Act 1969 recognises five different types of evidence or proof of paternity:

(1) a certified copy of the birth certificate showing the name of the father;

(2) an instrument signed by the mother of a child and a person acknowledging he is the father;

(3) an order made by a specified Court or public authority in a specified country outside New Zealand declaring a person to be the father of the child;

(4) a paternity order within the meaning of the Domestic Proceedings Act 1968; and

(5) a declaration of paternity made under section 10 of the Status of Children Act 1969.

A declaration of paternity is conclusive proof of paternity. The four remaining types of evidence are prima facie evidence of paternity only.

The most common and straightforward way for a father to become the legal father of a child is for him to jointly acknowledge that he is the legal father of the child with the child's mother and sign the child's birth certificate, or an instrument acknowledging that he is the father. However, if there is uncertainty or disagreement as to the paternity of a child, either upon the child's birth or later in the child's life, a paternity order or a declaration of paternity will be necessary to establish who is the legal father of the child.

The High Court or Family Court may make a declaration of paternity if it is proved to the Court's satisfaction that the relationship of father and child exists. ${ }^{16}$ Alternatively, the Court may make a declaration of non-paternity if it is proved to the Court's satisfaction that the relationship does not exist. ${ }^{17}$ The relationship referred to in $\mathrm{s} 10$ is the legal relationship between the father and the child not the biological relationship between the father and the child. ${ }^{18}$ Both declarations are a judgment in rem and therefore binding on all subsequent proceedings. The Court's ability to make declarations is not subject to time limitations as they can be made after the child, father, or both have died.

\footnotetext{
${ }^{15}$ Section 19(4)(a).

${ }^{16}$ Status of Children Act 1969, s 10(2).

${ }^{17}$ Section 10(3).

${ }^{18}$ Hemmes $v$ Young [2005] NZSC 47.
} 
The Family Court may alternatively grant a paternity order in accordance with the Family Proceedings Act $1980 .{ }^{19}$ A paternity order is conclusive evidence of paternity for the purpose of maintenance liability only, and does not bind the parties in any other proceedings save to the extent that, if a paternity order is made, it amounts in those other proceedings to prima facie evidence of paternity. ${ }^{20}$ Unlike a declaration of paternity made under the Status of Children Act 1969, a paternity order can only be made in regards to an ex-nuptial child, ${ }^{21}$ and an application for a paternity order cannot be made after the expiration of six years from the birth of the child. ${ }^{22}$ Finally, the Court may alternatively make an order of non-paternity if it is satisfied that the respondent to the proceedings is not the father of the child. ${ }^{23}$

In determining an application for a declaration of paternity or non-paternity, a statutory presumption of parenthood will apply depending on the relationship status between the mother of the child and the man alleged to be the father around the time of the child's conception. Section 5 of the Status of Children Act 1969 provides that a man who is married to the child's mother at the time of the child's birth is presumed to the child's legal father. Similarly, a man is presumed to be the legal father of a child born within 10 months of the end of his marriage to the child's mother. In regards to de facto couples, opinion is divided as to whether the presumption of parenthood applies. ${ }^{24}$ While some commentators see the Status of Children Amendment Act 1987 (which applies to de facto partners as well as married couples) as widening the ambit of the Status of Children Act $1969,{ }^{25}$ the majority do not. ${ }^{26}$ Finally, the presumption is not conclusive and can be rebutted, with the onus on the father to produce rebuttal evidence. Every question of fact that arises in regards to the presumption is decided on a balance of probabilities. ${ }^{27}$

More generally, every question of fact that arises in determining an application for a declaration of paternity or a paternity order must be decided on a balance of probabilities. $^{28}$ In the leading judgment on the standard of proof in the context of

\footnotetext{
${ }^{19}$ Family Proceedings Act 1980, s 51(1).

${ }^{20}$ Family Proceedings Act 1980, s 51(2).

${ }^{21}$ Section 47(2).

${ }^{22}$ Section 49(1). However s 49(2) provides various exceptions to this rule.

${ }^{23}$ Section 51(1)(b).

${ }^{24}$ The issue turns on the interpretation of s 5(1) of the Status of Children Act 1969 and ss 1 and 2 of the Status of Children Amendment Act 1987.

${ }^{25}$ Henaghan et al Family Law in New Zealand (11ed, LexisNexis, Wellington, 2003) vol 1 at [6.504].

${ }^{26}$ The Laws of New Zealand (Butterworths, Wellington, 2001) at [111].

${ }^{27}$ Status of Children Act 1969, s 5(2).

${ }^{28}$ Status of Children Act 1969, s 10(6).
} 
paternity proceedings, ${ }^{29}$ Wild CJ did not accept all the evidence of the applicant mother, but indicated that her evidence was preferable to that of the alleged father and his witnesses. He held that the matter was "basically one of credibility" and that the Court must be satisfied from the evidence on a balance of probabilities that the respondent is the child's father, due weight being given to the gravity of the applicant's allegation of paternity against the respondent. ${ }^{30}$ Furthermore, a "sneaking suspicion" does not displace proof on a balance of probabilities. ${ }^{31}$

The most conclusive evidence of paternity is the result of a parentage test. Section 54 of the Family Proceedings Act 1980 provides that where the parentage of a child is an issue, the Court may recommend that parentage tests be carried out on the child and any person who may be the natural parent of the child. ${ }^{32}$ The result of the test can be used to support or rebut a statutory presumption of parenthood, or as evidence in proceedings regarding an ex-nuptial child in which the statutory presumption of parenthood does not apply. While the Court can recommend a parentage test, it should be noted that the Court cannot order a parentage test. However, if a party refuses to consent to the test the Court may draw any inferences it thinks proper, subject to the right of the refusing party to explain his or her reasons. ${ }^{33}$ Where the Court concludes the results of a parentage test are vital to determine the parentage of the child, the Court may place the child under the guardianship of the Court ${ }^{34}$ and provide the required consent to enable the child to undergo a parentage test. ${ }^{35}$ Courts have expressed frustration regarding the inability to order parentage tests and the Law Commission has recommended that s 54 be amended to allow Courts to order parentage tests, ${ }^{36}$ but no such amendment has yet been made.

\section{Establishing fathers as legal parents of children born as a result of specified AHR procedures}

The provisions in Part 2 of the Status of Children Act 1969 determine who are the legal parents of children born as a result of specified AHR procedures involving the use of donated gametes. ${ }^{37}$ Collectively, the provisions provide that legal parenthood is based on the psychological commitment of the social parents rather than on a

\footnotetext{
${ }^{29}$ Hall $v$ Vail [1972] NZLR 95.

${ }^{30}$ Ibid, at 96.

${ }^{31}$ See for example Cook $v$ Gibbons (1986) 3 FRNZ 257.

${ }^{32}$ Family Proceedings Act 1980, s 54(1).

${ }^{33}$ Section 57(2).

${ }^{34}$ Care of Children Act 2004, s 31.

${ }^{35} T$ v S [Guardianship] [2005] NZFLR 466 (CA).

${ }^{36}$ Law Commission New Issues in Legal Parenthood (NZLC R88, 2005) at [5.76].

${ }^{37}$ Part 2 was inserted by the Status of Children Amendment Act 2004 which repealed the Status of Children Amendment Act 1987.
} 
biological blood line. ${ }^{38}$ Therefore, a child's legal father in this context is usually not the child's biological father.

Where donated sperm is used either by itself or in an embryo, and the mother has undergone the procedure with her partner's consent, the mother's partner is for all purposes the legal parent of any child of the pregnancy. ${ }^{39}$ Consent is presumed, although any question of fact that arises will be determined on a balance of probabilities. $^{40}$ Non-partner donors are excluded from legal parenthood, unless subsequent to the time of conception they become the mother's partner. ${ }^{41}$ Furthermore, the presumptions of paternity in Part 2 override any conflicting evidence of paternity that could arise by virtue of Part 1 , including a declaration of paternity or a paternity order. $^{42}$

Finally, Part 2 of the Act is also subject to Part 3 of the Human Assisted Reproductive Technology Act 2004 which provides detailed provisions in regards to the collection and storage of identifying information of donors and their offspring. The provisions aim to ensure that donor offspring are able to access information about their genetic origins. ${ }^{43}$ Accordingly, when the child reaches 18 years of age, information about the donor (who is their biological parent) must be provided to him or her upon request. ${ }^{44}$

\footnotetext{
${ }^{38}$ Henaghan et al Family Law in New Zealand (13 ${ }^{\text {th }}$ ed, Lexis Nexis, Wellington, 2007) vol 2 at [10.2].

${ }^{39}$ Status of Children Act 1969, s 18.

${ }^{40}$ Section 27.

${ }^{41}$ Status of Children Act 1969, s 22.

${ }^{42}$ Section 26.

${ }^{43}$ Human Assisted Reproductive Technology Act 2004, s 4(e).

${ }^{44}$ Section 50.
} 


\section{Guiding principles in paternity proceedings}

The following New Zealand legal principles relate to various aspects of paternity and are drawn from the Status of Children Act 1969, the Family Proceedings Act 1980, the Care of Children Act 2004, the Child Support Act 1991, and the Human Assisted Reproductive Technology Act 2004. The principles are either well established and authoritative, or relatively new. Some can be applied concurrently while others conflict. These principles, and their relative importance, will be used in each of the following three chapters to explain outcomes under the current legal framework and to provide a basis for the main arguments put forward and recommendations made.

The two core principles of this dissertation are principles $\mathrm{A}$ and $\mathrm{B}$ as these are the two core principles of legal parenthood. Principles $\mathrm{C}$ to $\mathrm{F}$ are subsidiary principles that supplement principles A and B.

\section{A Legal parenthood is based on a biological relationship between the parent and the child $^{45}$}

It is well established in law that a child's biological mother is the child's legal mother. Although there is no explicit statutory definition of a legal father, the combined effect of relevant legislation is that the legal father of a child is his or her biological father. ${ }^{46}$

\section{$B$ The legal parenthood of children born as a result of specified AHR procedures is based on the psychological commitment of the intended social parents ${ }^{47}$}

An exception to the legal connection between biology and parenthood has been created because of new assisted reproductive technologies. The provisions in Part 2 of the Status of Children Act 1969 essentially provide for parenthood to be based on the psychological commitment of the intended social parents rather than on a biological blood line. $^{48}$

\section{There should be certainty about the legal status of children in relation to their parents}

The certainty of a child's status in relation to their mother is rarely an issue. However, the status of a child in relation to their father can be uncertain depending on the circumstances of the child's conception. Section 8 of the Status of Children Act 1969 provides a list of instruments that prove paternity and determine the status of children

\footnotetext{
${ }^{45}$ Bar adoption, which is a notable exception this principle.

${ }^{46}$ Status of Children Act 1969, s 7, s 8, and s 10; Family Proceedings Act 1980, s 2 as amended by schedule 3 of the Care of Children Act 2004.

${ }^{47}$ Bar surrogacy, which is a notable exception this principle.

${ }^{48}$ Henaghan et al Family Law in New Zealand (13 ${ }^{\text {th }}$ ed, Lexis Nexis, Wellington, 2007) vol 2 at [10.2].
} 
in relation to their fathers, thus providing certainty in terms of their status. A declaration of paternity provides the most certainty in terms of the child's status as it is a judgment in rem. A paternity order, a signed copy of the child's birth certificate and various other mechanisms provide prima facie evidence of paternity and certainty about the child's status in the absence of any other conflicting evidence.

The provisions in Part 2 of the Status of Children Act 1969 were inserted to remove the previous uncertainty about the status of children born as a result of AHR procedures. Section 13(1) specifically provides that one of the main purposes of the Act is to remove uncertainty about the status of children conceived as a result of AHR procedures.

It should be noted that the Act only provides for the certainty of a child's status at a certain point in time. It does not provide that there should be certainty in terms of the child's status over their lifetime, in other words that the child's status is fixed. The status of a child can change over time for various reasons. For example, adoption changes the legal status of a child in relation to their biological parents. ${ }^{49}$ In cases of misattributed paternity, the child's legal status in relation to their legal father can change if it is proven he is not the child's biological father. ${ }^{50}$ Finally, a child born as the result of an AHR procedure may 'acquire' a legal parent if the donor subsequently becomes the partner of the child's mother. ${ }^{51}$

\section{Error, lack of consent and deceit can affect legal parenthood in some circumstances}

As previously noted, principles A and B are the core principles of legal parenthood. However, there are three subsidiary principles (D(i)-(iii)) that can provide full or partial exceptions to principles A or B. These conflicting principles concern three factors: lack of consent, error, and deceit.

There is only one principle in the Status of Children Act 1969 which recognizes that consent (or lack of) affects legal parenthood, namely:

(i) When a partnered woman becomes pregnant as the result of an AHR procedure using the semen of a man who is not her partner, he will only become the legal parent of the child if he consented to the AHR procedure

This principle can be found in s 18 of the Status of Children Act 1969 which provides that:

\footnotetext{
${ }^{49}$ Adoption Act 1955, s 16.

${ }^{50}$ Status of Children Act, s 10(3).

${ }^{51}$ Status of Children Act 1969, s 24.
} 
18 When woman's non-donor partner is parent, and non-partner semen donor or ovum donor is not parent

(1) This section applies to the following situation:

(a) a partnered woman (woman A) becomes pregnant as a result of an AHR procedure:

(b) the semen (or part of the semen) used for the procedure was produced by a man who is not woman A's partner or, as the case requires, the ovum or embryo used for the procedure was produced by, or derived from an ovum produced by a woman who is not woman A's partner:

(c) woman A has undergone the procedure with her partner's consent.

(2) In that situation, woman A's partner is, for all purposes, a parent of any child of the pregnancy.

Section 18 is subject to $\mathrm{s} 22$ which provides that the consent of the woman's partner is presumed. However, if he can rebut the presumption by pointing to evidence that he did not consent to the AHR procedure then he does not become the child's legal parent. Instead, the woman who has undergone the AHR procedure is deemed to be a 'woman acting alone' and is the sole legal parent of the child. ${ }^{52}$

Similarly, there is only one principle in the Status of Children Act 1969 which recognises that error or deceit affects legal parenthood, namely:

(D)(ii) Proof of an error (resulting from deceit or mistake) regarding the existence of a biological relationship between the legal parent and the child will end the legal relationship of parent and child

This principle is encapsulated in s 10(3) of the Act which provides that a Court may make a declaration of non-paternity (whether the alleged father or the alleged child or both of them are living or dead) if it is proved to the Court's satisfaction that the relationship does not exist.

The final principle provides a partial exception to principle A as it does not provide an exception to legal parenthood but rather an exception to one of the most important aspects of legal parenthood, namely child support:

(iii) The circumstances of a child's conception can determine whether the child's biological parent is liable to pay child support

This principle is encapsulated in s 89Z of the Child Support Act 1990 which provides that the Commissioner of Inland Revenue must exempt a biological parent from paying child support if that person was the victim of a sex offence which resulted in the conception of the qualifying child. This provision provides the only full exemption to child support liability.

\footnotetext{
${ }^{52}$ Status of Children Act 1969, s 14.
} 


\section{$E$ Males and females must provide consent to the use of their gametes in order for them to be used in an AHR procedure}

The Human Assisted Reproductive Technology Act 2004 provides a legislative framework for controls on assisted reproductive technology. The Act provides that all persons exercising powers or performing functions under the Act must be guided by the seven principles of the Act. One such principle is that no AHR procedure should be performed on an individual unless the individual has made an informed choice and given informed consent. ${ }^{53}$ AHR procedure is defined in s 5 of the Act as a procedure performed for the purpose of assisting human reproduction that involves:

(a) the creation of an in vitro human embryo; or

(b) the storage, manipulation, or use of an in vitro human gamete or an in vitro human embryo; or

(c) the use of cells derived from an in vitro human embryo; or

(d) the implantation into a human being of human gametes or human embryos; but does not include an established procedure.

It is important to note that the exclusion of established procedures from the definition of an AHR procedure creates a loophole in that on a strict interpretation of the Act s 4(d) does not apply to established procedures. In other words it is not a requirement that an individual give informed consent before an established procedure is performed on them. The Human Assisted Reproductive Technology Order 2005 provides a list of established procedures which includes two common procedures: artificial insemination and in vitro fertilisation (IVF). However, presumably it was not the intent of Parliament to require informed consent for AHR procedures and not established procedures, and regardless, the loophole is arguably closed by the Health and Disability Commissioner (Code of Health and Disability Services Consumer's Rights) Regulations 1996. Right 7 provides that consumers of health and disability services have the right to make an informed choice, give informed consent, and withdraw consent. ${ }^{54}$ Section 10 (a) of Right 7 specifically provides that no body part or bodily substance removed or obtained in the course of a health care procedure may be stored, preserved, or used otherwise than with the informed consent of the consumer. Body part or bodily substances would logically include male and female gametes.

Furthermore, the Human Assisted Reproductive Technology Act 2004 provides that the Governor-General may, by Order of Council, make regulations that prescribe requirements for informed consent for the collection of gametes and embryos in connection with the performance of AHR procedures or any other lawful use of the

\footnotetext{
${ }^{53}$ Human Assisted Reproductive Technology Act 2004, s 4(d).

${ }^{54}$ Health and Disability Commissioner (Code of Health and Disability Services Consumer's Rights) Regulations 1996, Right 7.
} 
gametes or embryos. ${ }^{55}$ No such requirements have yet been made but if and when they are made, it is a statutory requirement that they cannot be inconsistent with the Code of Health and Disability Services Consumers' Rights. Therefore the combined effect of the Human Assisted Reproductive Technology Act 2004 and the Code of Health and Disability Services Consumers' Rights is that men and women must give informed consent to the use of their gametes in order for them to be used in an AHR procedure or an established procedure.

\section{F Children should be able to access information about their genetic origins}

A clear principle of the Human Assisted Reproductive Technology Act 2004 is that children conceived as the result of an AHR procedure involving one or more donors should be made aware of their genetic origins and be able to access information about their origins. ${ }^{56}$ Part 3 of the Act contains detailed provisions about the collection, storage and access to information concerning donors and children conceived using donated sperm, eggs or embryos. Significantly, on reaching 18 years of age, the child must be provided with information about the relevant donor upon their request. ${ }^{57}$

Naturally conceived children do not have the same guaranteed access to information about their genetic origins. While it will usually be clear who the child's biological mother is, it may be less clear who the child's biological father is as the child's birth certificate may not record the name of the child's father, or the named father may in fact not be the child's biological father. In civil proceedings where the parentage of a child is an issue the Court may recommend a parentage test be carried out to obtain or clarify information on the child's genetic origins, although the Court does not have the statutory authority to order a parentage test. ${ }^{58}$ However, if the Court concludes the results of a parentage test are vital to determine the parentage of the child, the Court may place the child under the guardianship of the $\operatorname{Court}^{59}$ and provide the required consent to enable the child to undergo a parentage test. ${ }^{60}$

\section{G Welfare and best interests of the child}

Finally, it is important to note that one of the paramount principles of family law is not a relevant principle in terms of determining legal parenthood and will therefore not be used in this dissertation. Section 4 of the Care of Children Act 2004 provides

\footnotetext{
${ }^{55}$ Human Assisted Reproductive Technology Act 2004, s 76(1A).

${ }^{56}$ Section 4(e).

${ }^{57}$ Section 50.

${ }^{58}$ Family Proceedings Act 1980, s 54.

${ }^{59}$ Care of Children Act 2004, s 31.

${ }^{60}$ See T v S [Guardianship] [2005] NZFLR 466 (CA) and more recently Fletcher v Blackburn [Guardianship] [2009] NZFLR 354 (HC).
} 
that the child's welfare and best interests must be the first and paramount consideration in the administration and application of the Act and in any other proceedings involving the guardianship of, or the role of providing day-to-day care for, or contact with, a child.

Legal parenthood is determined by the Status of Children Act 1969 and proceedings concerning legal parenthood do not involve any of the matters described in s 4 . Therefore it is not applied in proceedings regarding legal parenthood. Exclusion of the consideration of the welfare and best interests of the child has been confirmed by the Family Court, although the Court has noted that some regard should be had to the child's welfare pursuant to the articles contained in the United Nations Convention on the Rights of the Child (UNCROC). ${ }^{61}$ Where possible this dissertation will consider the articles, although it must be noted they are not strictly part of New Zealand domestic law but rather part of New Zealand's international obligations. Therefore, they are a secondary consideration to the principles and provisions in New Zealand legislation.

While the welfare and best interests of the child principle is not relevant in regards to determining legal parenthood, it can be relevant in regards to proving parentage. The Court will have regard to ss 4 and 5 of the Care of Children Act 2004 when deciding whether to place a child under the guardianship of the Court for the purpose of the Court granting consent to a parentage test. ${ }^{62}$

\footnotetext{
${ }^{61}$ See for example $L v R$ FC Nelson FAM-2005-042-489, 21 September 2007 at [36].

${ }^{62}$ See $T$ v S [Guardianship] [2005] NZFLR 466 (CA) and more recently Fletcher v Blackburn [Guardianship] [2009] NZFLR 354 (HC).
} 


\section{Non-consensual artificial paternity}

\section{A Introduction}

Advances in assisted reproductive technology have provided new ways for women and men to use their own genetic material, as well as that of donors, to conceive children. This section analyses non-consensual artificial paternity that can arise from the misuse of such technology to conceive a child. More specifically, non-consensual artificial paternity results from the use of a male's semen (or embryos created using his semen) by a female in an AHR procedure without his consent to conceive a child. The AHR procedure could include an artificial insemination procedure using the male's semen, or the implantation of embryos created using the male's semen.

This type of paternity can occur when a couple agree to store semen samples or embryos for future use but then separate, and after the separation the female party goes ahead with an AHR procedure using the samples without the knowledge of her former partner and conceives a child. Alternatively, the couple may have begun fertility treatment using the samples and separate in the course of treatment, and after the separation the female party continues treatment without the knowledge of her former partner and conceives a child.

These types of scenarios are complex as the samples may provide the female party with her only chance of having a genetically related child if they were stored before she underwent medical treatment which resulted in infertility, or if she has reached an age where her fertility levels are so low that she cannot conceive a child naturally. In contrast, the male party may no longer want to become a parent or he may want to become a parent but not with a former partner.

While scenarios involving non-consensual artificial paternity are currently rare, they may increase as more couples decide to store samples for medical reasons and undergo treatment later in life when their fertility levels are low, and earlier on in relationships when they are perhaps more unstable. In addition, without rigid requirements to ensure the consent of both parties is still valid at the time of implantation, it may be relatively easy for the female party to deceive a fertility treatment provider and use stored samples without the knowledge or consent of her former partner. This could be done, for example, by failing to inform the provider that she and her partner have separated, or by forging her former partner's signature on the necessary consent forms.

The main issue analysed in this chapter is the effect of the biological father's lack of consent to the use of his semen (or embryos created using his semen) on his status as a 
legal father. In other words, is a male who did not consent to an AHR procedure involving the use of his semen (or embryos created using his semen) the legal father of the resulting child?

This issue has not yet arisen in New Zealand ${ }^{63}$ although in England two female plaintiffs have previously sought a court order to allow them to use embryos created with the semen of their former partners without their consent. ${ }^{64}$ The landmark judgment was appealed the Court of Appeal $^{65}$ and then to the European Court of Human Rights. ${ }^{66}$ In England there have also been media reports of a female who tricked a fertility clinic into allowing her to use the semen of her former partner to conceive two children. ${ }^{67}$ A number of cases have also arisen in the United States which explore the use of embryos post separation and the right to become, or not to become, a parent. ${ }^{68}$ These examples raise important questions concerning the right to reproductive autonomy for both men and women. New Zealand is in a position to learn from developments in other countries and consider the various issues before a test case comes before the Family Court in New Zealand.

\section{B Under the current New Zealand legal framework, is a male who did not consent to an AHR procedure involving the use of his semen (or embryos created using his semen) the legal father of the resulting child?}

To put this question into context, consider the following hypothetical scenario:

Michelle and Ryan, a busy professional couple, marry at the age of 40. After learning they may have problems conceiving a child in future due to age and health concerns, they decide to undergo fertility treatment that involves the creation of embryos (using Michelle's eggs and Ryan's semen) and storage of the embryos for potential use in future. Three years later the relationship breaks down and the couple separate. A year after the separation Michelle decides to use the embryos to conceive a child as they now provide her with her last chance of having a child which she desperately wants. Ryan has since found a new partner and has relocated to Australia. Without informing Ryan of her intention to use the embryos or the fertility clinic of her separation from

\footnotetext{
${ }^{63}$ At present there is no data available in New Zealand or internationally on the number of children conceived in this type of scenario.

${ }^{64}$ Evans v Amicus Healthcare Ltd [2003] EWHC 2161 (Fam).

${ }^{65}$ Evans $v$ Amicus Healthcare Ltd [2004] EWCA Civ 727.

${ }^{66}$ Evans v United Kingdom [2006] 1 FCR 585 (ECHR).

${ }^{67}$ See for example "Husband discovered he was a father of two after estranged wife forged his signature in IVF deception" (3 March, 2008) London Evening Standard <www.standard.co.uk>

${ }^{68}$ Davis v Davis 842 SW 2d 588 (Tenn 1992); Kass v Kass 91 NY 2d 554 (1998); AZ v BZ 431 Mass 150 (2000); Litowitz v Litowitz 10 P 3d 1086 (Wash Ct App 2000); JB v MB 783 A 2d 707 (NJ 2001).
} 
Ryan, Michelle undergoes an embryo implantation procedure and conceives a child. She gives birth nine months later.

Section 5 in Part 1 of the Status of Children Act 1969 and ss 18, 14 and 22 in Part 2 of the Act are the most appropriate provisions to determine whether Ryan is the legal father of the child. As there is no reported case law in New Zealand on this issue only legislative provisions shall be used. The relevant provisions are listed below:

\section{Presumptions as to parenthood}

(1) A child born to a woman during her marriage, or within 10 months after the marriage has been dissolved by death or otherwise, shall, in the absence of evidence to the contrary, be presumed to be the child of its mother and her husband, or former husband, as the case may be.

(2) Every question of fact that arises in applying subsection (1) shall be decided on a balance of probabilities.

(3) This section shall apply in respect of every child, whether born before or after the commencement of this Act, and whether born in New Zealand or not, and whether or not his father or mother has ever been domiciled in New Zealand.

18 When woman's non-donor partner is parent, and non-partner semen donor or ovum donor is not parent

(1) This section applies to the following situation:

(a) a partnered woman (woman A) becomes pregnant as a result of an AHR procedure:

(b) the semen (or part of the semen) used for the procedure was produced by a man who is not woman A's partner or, as the case requires, the ovum or embryo used for the procedure was produced by, or derived from an ovum produced by a woman who is not woman A's partner:

(c) woman A has undergone the procedure with her partner's consent.

(2) In that situation, woman A's partner is, for all purposes, a parent of any child of the pregnancy.

Section 18 must be read in accordance with the definition of 'partnered woman' in $\mathrm{s}$ 14 which provides that:

partnered woman means a woman who-

(a) is married or in a civil union; or

(b) is married or in a civil union, but is living with a man, or with another woman, as a de facto partner; or

(c) is not married or in a civil union but is living with a man, or with another woman, as a de facto partner 
Finally s 22 provides that:

\section{Woman acting alone: non-partner semen donor not parent unless later becomes mother's partner}

(1)

This section applies to the following situation:

(a) a woman acting alone becomes pregnant as a result of an AHR procedure:

(b) the semen used for the procedure was produced by a man (man A) who is not her partner.

In that situation, man A is not, for any purpose, a parent of any child of the pregnancy unless man A becomes, after the time of conception, the woman's partner (in which case the rights and liabilities of man A, and of any child of the pregnancy, are determined in accordance with section 24).

As the child was conceived as a result of an AHR procedure the logical starting point is s $18 .{ }^{69}$ In accordance with s $18(1)$ the first question to consider is whether Michelle is a 'partnered woman.' The definition of partnered woman includes a woman who is married. As Ryan and Michelle are separated but still legally married, Michelle does fall within the definition of a partnered woman. Section 18(2) provides that the semen used for the procedure was produced by a man who is not the woman's partner. As Ryan is Michelle's partner for the purposes of s 18, the section does not apply. Therefore, s 5 becomes the most appropriate provision to determine whether Ryan is the legal father of the child. As Ryan and Michelle were legally married at the time of the procedure, the statutory presumption of parenthood will apply to Ryan. Furthermore, he will not be able to rebut the presumption as he is the child's biological father.

Now suppose Michelle and Ryan were previously living together in a de facto relationship before they separated and Michelle underwent the procedure. In this scenario Michelle is a not a 'partnered woman' as she was not living in a de facto relationship with Ryan at the time she underwent the AHR procedure, therefore s 18 does not apply. ${ }^{70}$ In addition the statutory presumption of parenthood in $\mathrm{s} 5$ does not apply to Ryan, as the section only includes married partners (who may be separated but are still legally married or in a civil union). Instead, s 22 would apply in this scenario and the outcome of the application of the section would be that Ryan is not the legal father of the child. This is because 'woman acting alone' includes Michelle

\footnotetext{
${ }^{69}$ The type of procedure Michelle has undergone does not involve a donor so it does not strictly fall within the definition of an AHR procedure in s 15. However, for the purposes of this dissertation an extended definition is used by virtue of s 14(1) on the interpretation of the Act which provides that an AHR procedure is that defined in $\mathrm{s} 15$ 'unless the context otherwise requires'.

${ }^{70}$ Although depending on the specific facts regarding the relationship Michelle could argue that she is still in a de facto relationship using the definition of de facto partner provided in section $29 \mathrm{~A}$ of the Interpretation Act 1999.
} 
as a non-partnered woman, ${ }^{71}$ and the semen used in the procedure was produced by a man who was not her partner, namely Ryan. ${ }^{72}$ The outcome of the application of s 22 , and the inability to apply ss 18 or 5 to this particular fact pattern is that the child has no legal father and therefore only one legal parent, namely Michelle. The only way the child could possibly have a legal father is if Ryan re-partnered with Michelle. However, considering the circumstances this is very unlikely.

Finally, suppose Michelle had re-partnered with a different man named Tim and was either married to him, in a civil union, or living with him as a de facto partner when she underwent the procedure. Applying s 18, Michelle is a partnered woman because of her relationship with Tim. The semen used for the procedure was produced by a man who is not her partner, namely Ryan. Finally, Tim's consent to the procedure is required which is presumed in absence of evidence to the contrary. ${ }^{73}$ If Tim did consent he will become the child's legal father. Even in the scenario where Ryan and Michelle are still legally married but Michelle is in a de facto relationship with Tim, Michelle's new de facto partnership with Tim will result in Tim 'trumping' Ryan as a the child's legal parent, as s 26 provides that s 18 has effect despite any conflicting evidence of paternity. If for some reason Tim did not consent and can prove on the balance of probabilities he did not consent, ${ }^{74}$ he will not become the child's father. The child will therefore have no legal father and only one legal parent, namely Michelle.

The overall application of the current legal framework to the scenario involving Ryan and Michelle, and other variations of the scenario, demonstrate that unusual and inconsistent outcomes can result. There is clearly a lack of certainty about the status of the children in relation to their biological fathers in these types of scenarios as the creation of the legal relationship is dependent on a variable factor, namely whether or not the child's mother has re-partnered at the time she underwent the AHR procedure.

\section{The main principles supporting the current legal framework}

The current legal framework on legal parenthood is made up of provisions from Part 1 and Part 2 of the Status of Children Act 1969. The two parts of the Act are distinct and are not designed to be applied concurrently ${ }^{75}$ as they are based on conflicting principles $\mathrm{A}$ and $\mathrm{B}$ :

\footnotetext{
${ }^{71}$ Status of Children Act 1969, s 14(1).

${ }^{72}$ Section 22.

${ }^{73}$ Section 27(1).

${ }^{74}$ Section 27(2).

${ }^{75}$ Section 26.
} 
(A) Legal parenthood is based on a biological relationship between the parent and the child

(B) The legal parenthood of children born as a result of specified AHR procedures involving donors is based on the psychological commitment of the intended social parents rather than on a biological relationship

While s 13 specifies that one of the main purposes of Part 2 is to remove uncertainty about the status of children conceived as a result of AHR procedures, application of the current legal framework results in unusual and uncertain outcomes in this particular context. Therefore, the current legal framework does not uphold principle $\mathrm{C}$ which provides that:

(C) There should be certainty about the legal status of children in relation to their parents

Furthermore, while the current legal framework does not take into account the biological father's lack of consent to the AHR procedure, it does recognise that if the biological mother has a new partner when she undergoes the procedure, he will become the child's legal parent if he consents to the procedure. This outcome is in accordance with principle $\mathrm{D}(\mathrm{i})$ which provides that:

(D)(i) When a partnered woman becomes pregnant as the result of an AHR procedure using the semen of a man who is not her partner, her partner will only become the legal parent of the child if he consented to the AHR procedure

Finally, the current legal framework does not uphold principle E which provides that:

(E) Men and women must provide consent to the use of their gametes in order for them to be used in an AHR procedure

This is evident in the fact that the biological father's lack of consent to the AHR procedure is currently not a relevant factor to determine whether he should be the child's legal father.

\section{Dissertation argument}

Determining the legal parenthood of a male and a female who have undergone an AHR procedure using their own gametes will usually be a straightforward noncontentious matter. This is because both parties are likely to be married, in a civil union or in a de facto relationship with each other and both are likely to have consented to the AHR procedure and intend to become legal parents. In such cases, the provisions in Part 1 of the Status of Children Act are suitable to determine legal parenthood. 
However, the circumstances surrounding such an AHR procedure will not always be straightforward, as demonstrated by the hypothetical scenario involving Ryan and Michelle. This is because fertility treatment can be a protracted and stressful process which results in the breakdown of relationships, and one party (most likely the female party) may wish to continue with treatment to conceive a child while the male party does not. The female party may particularly want to proceed with the AHR procedure if the stored semen samples or embryos provide her last change of conceiving a child. Such complex scenarios may occur more frequently as increasing numbers of couples undergo fertility treatment, particularly at an older age when their fertility rate is low, and in the earlier stages of a relationship when the relationship is more unstable.

This dissertation argues that the current legal framework on legal parenthood made up from provisions from Part 1 and Part 2 of the Status of Children Act 1969 are not designed to determine the legal parenthood of a biological father who did not consent to the AHR procedure which resulted in the conception of a child. The provisions in Part 1 do not allow for consideration of the biological father's lack of consent to the AHR procedure which is a key factor, and the provisions in Part 2 are designed specifically for AHR procedures involving a donor ${ }^{76}$ not AHR procedures involving two people who are using their own gametes. Therefore, a specific provision needs to be formulated and inserted into the Act to determine the legal parenthood of a biological father who did not consent to the AHR procedure which resulted in the conception of a child.

In the following analysis, the relevant principles that could be used to formulate this provision are identified and analysed. The conclusions drawn from this analysis are then used to provide the basis for the provision which is designed to be directly inserted into Part 2 of the Act.

(i) Which of the two core principles of legal parenthood should form the basis of the proposed provision?

Principle A and principle B are the two core principles of legal parenthood. Both of these conflicting principles are present in the current legal framework used to determine the legal parenthood of a biological father who did not consent to the AHR procedure which resulted in the conception of a child. Because this results in uncertainty in outcomes, only one of the principles should be used to form the basis of the proposed provision.

\footnotetext{
${ }^{76}$ Or potentially two donors.
} 
Principle B emphasises that the legal parents of a child born as a result of an AHR procedure should be those who will be the child's social parents and have a psychological commitment to the child. This principle is the basis for the provisions in Part 2 of the Status of Children Act 1969 which provide that a donor does not become the child's legal parent because even though there is a biological relationship between the donor and the child, the donor is not going to be the child's social parent and has no psychological commitment towards the child. However, a donor becomes the child's legal parent if he subsequently partners with the child's biological mother after she has undergone the AHR using his semen. This is because the law recognises that by virtue of the relationship with the child's mother the donor intends to be the child's social parent and has a psychological commitment to the child. Similarly, nondonor partners of women who undergo AHR procedures involving a donor's semen are assumed to be the child's social parent and to have a psychological commitment to the child by virtue of their relationship with the child's biological mother.

The proposed provision should be based on principle B because in the current context the biological father could be regarded as in a similar position to a donor. He has a biological relationship with the child but at the time the mother underwent the AHR procedure he did not intend to be the child's social parent and had no psychological commitment to child. This is demonstrated by the fact that he was not in a relationship with the child's mother nor did he consent to the use of his semen or embryos created using his semen in the AHR procedure. In some cases he may be completely unaware that the child's mother underwent the AHR procedure.

Principle A should not be used to formulate the provision because it is too rigid for the current context. It does not take into account the complexities arising from AHR procedures where one gamete provider has provided consent and the other has not.

(ii) Which subsidiary principles should be used to formulate the provision?

It is argued that subsidiary principle $\mathrm{C}, \mathrm{D}(\mathrm{i}), \mathrm{E}$ and $\mathrm{G}$ should be used to formulate the provision. Firstly, the provision should remove the current uncertainty surrounding the child's legal status in relation to their biological father (principle $\mathrm{C}$ ).

Secondly, principle $\mathrm{D}(\mathrm{i})$ provides that a non-donor partner of a woman undergoing an AHR procedure using the semen of another man must consent to the procedure in order for him to become the child's legal parent. It is the only provision in the Act which recognises that lack of consent to an AHR procedure is a relevant factor in terms of legal parenthood. In practical terms, the effect of the provision is that if the 
non-donor partner consents to the procedure he becomes the child's legal parent, but if he does not consent to the procedure he does not become the child's legal parent.

Principle D(i) should be extended to include all men whose gametes are used by women who have undergone an AHR procedure resulting in the conception of a child, whether they are the woman's partner or not (although donors must be excluded). ${ }^{77}$ In other words, if a male consents to an AHR procedure involving the use of his gametes he becomes the child's legal parent. Alternatively, if he does not consent to the procedure he does not becomes the child's legal parent.

The extension of principle $\mathrm{D}(\mathrm{i})$ can be justified by principle E, which is a strong principle in the legal framework on AHR procedures. Principle E provides that men and women must consent to the use of their gametes in AHR procedures and more specifically, previously given consent can be withdrawn. The legal framework on AHR procedures and the legal framework on legal parenthood are inextricably linked because AHR procedures inevitably result in the conception of children and thus, legal parenthood. Therefore there should be continuity and consistency between the two legal frameworks. The current lack of continuity and consistency results in a major anomaly, namely, a person's consent is required in order for their gametes to be used in an AHR procedure, but if they are used without the person's consent, that person is still the child's legal parent.

It is logical and straightforward that men must consent to the use of their semen in an AHR procedure in order to become a child's legal parent. However, issues arise in scenarios where the AHR procedure involves the use of an embryo which contains the gametes of two people. As in the hypothetical scenario involving Ryan and Michelle, one party may consent to the use of the embryo while the other does not. It appears that Parliament contemplated such a scenario arising as s 76 of the Human Assisted Reproductive Technology Act 2004 provides that the Governor-General may make regulations on the use or destruction of in vitro gametes or in vitro embryos, in particular, without limitation, in cases where one party from whom such a gamete or embryo has been obtained or formed withdraws his or her consent to any course of action. ${ }^{78}$ However, no such regulations have been made thus far. Due to the absence of New Zealand regulations or case law on this matter, it is necessary to consider developments in other common law jurisdictions for guidance.

\footnotetext{
${ }^{77}$ The inclusion of donors would result in major inconsistencies with the current provisions regarding donors in the Status of Children Act 1969.

${ }^{78}$ Human Assisted Reproductive Technology Act 2004, s 76(1)(a)(ii).
} 
England was one of the first countries in the world to enact legislation regulating AHR procedures. The Human Fertilisation Embryology Act 1990 arguably contains the most comprehensive consent requirements in regards to embryo use. ${ }^{79}$ Section 6(3) of Schedule 3 provides that an embryo must not be used for any purpose unless there is an effective consent by each person whose gametes were used to bring about the creation of the embryo. Effective consent is consent which has not been withdrawn in writing. ${ }^{80}$

The statutory requirement that both gamete providers must consent to the use of the embryo was subsequently challenged in the landmark case of Evans $v$ Amicus Healthcare $L t d{ }^{81}$ It is the only reported case to arise in the common law jurisdiction concerning a female who sought to use embryos created using her gametes and that of her former partner without his consent. The plaintiff, Ms Evans, was diagnosed with cancer and was advised that the medical treatment she required could affect her fertility. She and her de facto partner underwent fertility treatment together which involved the creation and storage of embryos. Both parties signed forms consenting to the creation and storage of the embryos. Several years later the parties separated and Ms Evans' former partner contacted the fertility clinic, withdrew his consent to the continued storage of the embryos, and requested that they be destroyed. Ms Evans sought a declaration that her former partner had not, and could not, vary or withdraw his consent to the implantation of the embryos. She argued that the implantation of the embryos was part of the course of treatment she and her former partner had previously consented to, therefore they were still being treated together and his withdrawal of consent was ineffective.

The case turned on the interpretation of "treatment together" in s 28(3) of the Act in relation to the consent requirements contained in Schedule 3 of the Act, in particular $\mathrm{s}$ 26(3). If Ms Evans and her former partner were regarded as still receiving "treatment together" then the consent previously given by her former partner would still be valid. In a lengthy judgment the Court of Appeal dismissed her claim, stating: ${ }^{82}$

The point, however, remains whether or not the consent is still effective. This is essentially an issue of fact. The facts here are that both couples have separated, and no longer have any form of relationship with each other. In these circumstances, in my judgment, it cannot be said, as a matter of fact, that either couple in this case is still being treated together.

\footnotetext{
${ }^{79}$ Human Fertilisation and Embryology Act 1990.

${ }^{80}$ Schedule 3, para 1(3).

${ }^{81}$ Evans v Amicus Healthcare Ltd [2003] EWHC 2161 (Fam). In the first instance, there were two plaintiffs (Ms Evans and Ms Hadley) who brought identical claims. However, Ms Evans was the sole appellant.

${ }^{82}$ Evans v Amicus Healthcare Ltd [2004] EWCA Civ 727 at [147].
} 
The Court emphasised that: ${ }^{83}$

The need for the clinic to have an effective, continuing consent of both gamete providers pursuant to paragraph 6(3) of Schedule 3 at all times up to the transfer of the embryo into the woman is critical.

Accordingly, Ms Evans was prohibited from using the embryos. While leave to appeal to the House of Lords was refused, Ms Evans was granted leave to appeal to the European Court of Human Rights. ${ }^{84}$ She based her claim on breaches of the European Convention on Human Rights, such as the right to privacy and family life, which were unsuccessfully pleaded in the first instance and in the Court of Appeal. However, her appeal was unsuccessful. The Court refused to enter into a balancing exercise of the rights of the parties, instead relying on the exceptionally clear-cut legislation. ${ }^{85}$ The Court endorsed the overall conclusion of the Court of Appeal that one party cannot force biological (and thus legal parenthood) onto the other, regardless of the gender of the party who wishes to become a parent. On this point the European Court of Human Rights cited the comments of Wall J, made in the first instance, with approval: ${ }^{86}$

It is not difficult to reverse the dilemma. If a man has testicular cancer and his sperm, preserved prior to radical surgery which renders him permanently infertile, is used to create embryos with his partner; and if the couple have separated before the embryos are transferred into the woman, nobody would suggest that she could not withdraw her consent to treatment and refuse to have the embryos transferred into her.

While Ms Evans was ultimately unsuccessful in arguing that she should be able to use the embryos without her former partner's consent, her case prompted Parliament to amend the Human Fertilisation and Embryology Act 1990 to provide for a 12 month 'cooling off period' after consent by one party has been withdrawn. If both parties still do not consent to the use of the embryos after 12 months, they will then be destroyed. ${ }^{87}$ The reasoning from Evans was subsequently followed in In Re R (A Child) (IVF: Paternity of Child). ${ }^{88}$

In Australia, there is no national legislation that regulates assisted reproductive technology. However, three states have enacted state legislation that contains similar

\footnotetext{
${ }^{83}$ Ibid, at [141].

${ }^{84}$ Evans v United Kingdom [2006] 1 FCR 585 (ECHR).

${ }^{85}$ Ibid, at [249].

${ }^{86}$ Ibid, at [17].

${ }^{87}$ Human Fertilisation and Embryology Act 2008, Schedule 3, para 7.

${ }^{88}$ In Re R (A Child)(IVF: Paternity of Child) [2005] UKHL 33.
} 
statutory consent provisions concerning embryo use. ${ }^{89}$ The Western Australian Human Reproductive Technology Act 1991 provides that an embryo must not be used for any purpose unless there is effective consent by each person from whose gametes the embryo was derived. ${ }^{90}$ Either person can withdraw consent to the use of the embryo by giving notice, ${ }^{91}$ although consent cannot be withdrawn once the embryo has been used. ${ }^{92}$

The Victorian Assisted Reproductive Treatment Act 2008 provides that a woman may undergo an AHR procedure but only if the woman and her partner (if she has a partner) consent to the procedure. ${ }^{93}$ Consent can be withdraw by giving written notice $^{94}$ and cannot be withdraw after the procedure has taken place. ${ }^{95}$

Finally, the New South Wales Assisted Reproductive Technology Act 2007 provides that an ART provider must not provide ART treatment to a woman using a gamete except with the consent of the gamete provider. ${ }^{96}$ The gamete provider may revoke consent by giving written notice ${ }^{97}$ but must revoke consent before the embryo is implanted in the body of the woman. ${ }^{98}$ At present there is no existing Australian case law that tests any of the above provisions.

In Canada the Assisted Human Reproduction Act 2004 governs the use of embryos and provides consent requirements in regards to donors. It provides that no person shall make use of an in vitro embryo for any purpose unless the donor has given written consent, in accordance with the regulations, to its use for that purpose. ${ }^{99}$ In addition, s 2(d) provides that one of the overarching principles of the Act is that the principle of free and informed consent must be promoted and applied.

Finally, a number of American judgments have explored the use of embryos post separation. Davis $v$ Davis $^{100}$ was the first to determine whether a female is able to use

\footnotetext{
${ }^{89}$ The South Australian Assisted Reproductive Treatment Act 1988 (formerly called the Reproductive Technology Act 1988) delegates the power to the Governor to make regulations in regards to consent requirements although no regulations have been made thus far.

${ }^{90}$ Human Reproductive Technology Act 1991, s 22(1)(e)(i).

${ }^{91}$ Section 22(3).

${ }^{92}$ Section 22(4).

${ }^{93}$ Assisted Reproductive Treatment Act 2008, s 10(1)(a).

${ }^{94}$ Section 20(2).

${ }^{95}$ Section 11(1)(b).

${ }^{96}$ Assisted Reproductive Technology Act 2007, s 19.

${ }^{97}$ Section 17(3).

${ }^{98}$ Section 17(4)(b).

${ }^{99}$ Assisted Human Reproduction Act 2004, s 8(3).

${ }^{100}$ Davis v Davis 842 SW 2d 588 (Tenn 1992).
} 
embryos created using her former husband's semen without his consent. On appeal the Tennessee Supreme Court held that she could not use the embryos as it would be repugnant to order either party to bear the consequences of parenthood against his or her wish. However, the Court did suggest that if the party seeking to use the embryos had no other reasonable possibility of achieving parenthood, the use of the embryos should be considered. Davis $v$ Davis was followed by three similar judgments ${ }^{101}$ and a judgment concerning a male who wished to have embryos created using his ex wife's eggs implanted into another woman (his new partner). ${ }^{102}$ While based on different reasoning, the clear implication from all the above judgments is that the wishes of the progenitor wishing to avoid procreation are likely to be respected. ${ }^{103}$

Overall, analysis of statutory provisions from England, Australia and Canada and the judgment of Evans $v$ Amicus Healthcare Ltd demonstrate that there is a general consensus in the common law jurisdiction that both people whose gametes were used to create the embryo must consent to its use. This is further supported to a large extent by the American judgments briefly discussed. In addition, there is a general consensus in the common law jurisdiction that at the time the embryo is used, previously given consent is still effective if it has not been withdrawn by giving written notice, and after the embryo has been used consent cannot be withdrawn.

On that basis, in the scenario involving Ryan and Michelle, Ryan's consent to the use of the embryo is still effective at the time the embryo was implanted into Michelle because he had not withdrawn his consent in writing. However, it is argued that the consent of a male in Ryan's position should not still be effective simply because it has not been withdrawn in writing. Instead the test used to assess the consent of a nondonor partner at the time their partner underwent an AHR procedure should be used. The test provides that consent is determined on a balance of probabilities. ${ }^{104}$ It is not a requirement that a non-donor partner must withdraw his consent in writing in order to avoid becoming the child's legal parent. Therefore, to hold a male in Ryan's position to a higher standard, by requiring that consent must be withdrawn in writing, would be inequitable and inconsistent with the Act.

Based on these conclusions, an amended guiding principle for the proposed provision which encompasses principle $\mathrm{D}(\mathrm{i})$ and $\mathrm{E}$ is as follows: when a male's gametes (or

\footnotetext{
${ }^{101}$ Kass v Kass 91 NY 2d 554 (1998); AZ v BZ 431 Mass 150 (2000); Litowitz v Litowitz 10 P 3d 1086 (Wash Ct App 2000);

102 JB $v$ MB 783 A 2d 707 (NJ 2001).

${ }^{103}$ Henaghan and Atkin Family Law Policy in New Zealand (4 ${ }^{\text {th }}$ ed, Lexis Nexis, Wellington, 2013) at 297.

${ }^{104}$ Status of Children Act 1969, s 27(2).
} 
embryos containing his gametes) are used by a female in an AHR procedure the male becomes the father of the child if he consented to the AHR procedure. ${ }^{105}$ Whether or not a male has consented to the use of his gametes or embryos containing his gametes will be determined on the balance of probabilities.

Finally, in accordance with principle $\mathrm{F}$, the provision should ensure that the child can access information about their genetic origins so that it is consistent with the Human Assisted Reproductive Technology Act 2004.

\section{E Recommendations}

Recommendation 1: Insert a specific provision into Part 2 of the Status of Children Act 1969 to determine the legal parenthood of a male whose semen or embryos containing his semen were used in an AHR procedure without his consent.

The provision below has been drafted using a similar structure and language to existing provisions in Part 2 of the Status of Children Act 1969 for consistency.

\section{A When non-consenting male semen provider deemed donor}

(1) This section applies to the following situation:

A partnered or unpartnered woman (woman A) becomes pregnant as a result of an AHR procedure or an established procedure and:

(a) the semen (or part of the semen) used for the procedure was produced by a male who did not consent to the use of his semen in the procedure; or

(b) the embryo used for the procedure was produced by woman A's ovum and the semen of a male who did not consent to the use of the embryo in the procedure.

(2) In that situation, the male is, for all purposes, a donor and not the legal parent of any resulting child of woman A's pregnancy for the purposes of this Act; and Part 3 of the Human Assisted Reproductive Technology Act 2004.

(3) Every question of fact that arises in applying subsection (1) must be decided on a balance of probabilities.

Deeming a non-consenting male a donor instead of a legal parent reflects principle B because at the time of the child's conception he was not an intended social parent with a psychological commitment towards the child. Therefore he should not become the child's legal parent. The provision reflects principle $\mathrm{C}$ as it removes the current uncertainty in regards to the child's legal status towards their biological father. Finally, it reflects principle D(i) and E because the male's lack of consent to the AHR

\footnotetext{
${ }^{105}$ Except donors.
} 
procedure determines whether he becomes the child's legal father. Principle F is also reflected in the provision as the child will be able to access information about their genetic origins in accordance with Part 3 of the Human Assisted Reproductive Technology Act 2004.

It should be noted that a male who did not consent to the AHR procedure and thus the conception of the child may want to have a significant parenting role or simply have some contact with the child. In $K v P,{ }^{106}$ decided under the Guardianship Act 1968 and the Status of Children Amendment Act 1987, the High Court held that a sperm donor could not apply for custody or access as a "father" because he had "no rights and liabilities as a father." However, he could apply as "any other person." The Court subsequently granted the donor's application on the basis that it was in the child's best interests.

In cases of non-consensual artificial paternity, the biological father could apply for a parenting order under the Care of Children Act as "any other person" 107 although it is questionable whether such an application would be successful because under the Status of Children Amendment Act 2004 a donor is not a father "for any purpose." Therefore, to grant the order may be seen as going against parliamentary intent. However, if a strong argument was made that granting the order would be in the best interests of the child, the Court may take a different view.

Recommendation 2: The Governor General should pass an order of council in accordance with s 76(1)(ii) of the Human Assisted Reproductive Technology Act 2004.

This order of council would contain regulations on the use or destruction of in vitro gametes or in vitro embryos, in particular, without limitation, in cases where one party from whom such a gamete or embryo has been obtained or formed withdraws his or her consent to any course of action. Guidance on the wording of the regulations should be drawn from the English Human Fertilisation and Embryology Act 1990 as it provides the most comprehensive legislative scheme on consent requirements, although guidance could also be drawn from Australian legislation.

\footnotetext{
${ }^{106} K v P$ [2004] 2 NZLR 42.

${ }^{107}$ Care of Children Act 2004, s 47(1)(c). Leave must be granted by the Court before the application can be made.
} 


\section{$V$ Non-consensual natural paternity and deceitful natural paternity}

\section{A Introduction}

Non-consensual natural paternity results from the unplanned conception of a child after consensual sexual intercourse. The conception of the child may have resulted from a lack of contraception, faulty contraception or miscommunication regarding contraception. Similarly, deceitful natural paternity results from consensual sexual intercourse although it is a deliberate deceitful act by the child's mother that caused the conception of the child. She may have lied about her use of the contraceptive pill, pricked the condom, lied about infertility, or collected discarded semen (for example out of a used condom) and inseminated it into herself without the knowledge and consent of the male party. Similarly, semen could collected in the course of oral sex and be inseminated without the knowledge and consent of the male party.

There are many different circumstances in which an unplanned child may be conceived, for example: after a one night stand, during a short or long term relationship, during a marriage, or during a separation. Instances of deceitful paternity can occur in similar circumstances. At present there are no reliable statistics on the number of unplanned children as the data is perhaps too difficult to obtain, although arguably a considerable number of children are unplanned. Similarly, there are no reliable statistics on the number of children who were conceived as a result of deceit, although the growing number media reports on the topic, ${ }^{108}$ and anecdotal evidence, ${ }^{109}$ suggest instances of deceitful paternity do occur more than minimally.

In scenarios involving these types of paternity there is no dispute about who the biological father is. The main issue is whether a biological relationship between the father and child should always result in a legal relationship of father and child, regardless of the circumstances of the conception. While this issue has not yet come before the New Zealand Family Court, it has been explored in a highly publicised case in the United States. ${ }^{110}$ The case highlighted several important issues regarding reproductive autonomy and the right to become or not to become a parent, which are equally relevant to males and females in New Zealand. As attitudes towards reproductive autonomy and parenthood change over time, the New Zealand Family Court may soon have to grapple with some of these issues when raised in a test case.

\footnotetext{
${ }^{108}$ See for example Liz Jones "The Craving for a baby that drives women to the ultimate deception" (11 November 2011). <www.dailymail.co.uk>

${ }^{109}$ The comment stream under the article by Liz Jones received 1255 comments within 3 days of being published before it had to be closed. Many readers provided anecdotal evidence of other instances of deceitful paternity.

${ }^{110}$ Dubay v Wells and Attorney General 6 F.3d 422 (6th Cir, 2007).
} 


\section{B Under the current New Zealand legal framework, is a male who did not consent to becoming the legal father of a child or was deceived into becoming the legal father of a child nevertheless the child's legal father?}

To put this question into context, consider the following hypothetical scenario involving non-consensual natural paternity:

Scenario 1: Michael and Annabel, both 19 year old university students, meet at a mutual friend's party. That night they get drunk and have sexual intercourse but forget to use a condom. ${ }^{111}$ Two months later Annabel discovers she is pregnant and informs Michael that he is the father. Michael suggests that she have an abortion or give the child up for adoption as they are both still at university, not in a good financial position to raise a child, and barely know each other. After considering her options, Annabel decides to continue with the pregnancy and keeps the child.

Now consider the following scenarios involving deceitful natural paternity:

Scenario 2: Scott, 30, and Emma, 29, have been in a de facto relationship for two years. Both did not want to have children before getting married so it was agreed that Emma would take the contraceptive pill to avoid an unplanned pregnancy. When Scott is offered a job overseas Emma begins to suspect that he may break up with her and go alone as their relationship has become strained in recent months. Upset over the possibility of an impending break up she decides to deliberately stop taking the pill and does not tell Scott. A month later she discovers she is pregnant. When Scott questions how she could have become pregnant while on the pill, the two end up having a fight and Emma admits that she deliberately stopped taking her contraceptive pills in order to get pregnant so that they would stay together.

Scenario 3: Jeremy, 27 and Kylie, 39 meet online through an internet dating site. Kylie has been unable to find 'Mr Right' but is adamant she wants to have a child. Mindful of her decreasing fertility levels and the cost of undergoing fertility treatment using a sperm donor, she decides to attempt to get pregnant from a one night stand. Jeremy is not looking for a serious relationship as he and his long term girlfriend just broke up, but he is keen to get back into the dating scene. After exchanging a few emails they meet in a bar, have a few drinks, and subsequently have sexual intercourse. Jeremy uses a condom. After they have finished, Jeremy removes the condom and falls asleep. Unbeknown to Jeremy, Kylie immediately removes the semen from the condom, inseminates it into herself and as a result, becomes pregnant.

\footnotetext{
${ }^{111}$ Alternatively, the condom broke, Michael wrongly assumed Annabel was taking the contraceptive pill, or Annabel was taking the contraceptive pill but it failed to prevent pregnancy.
} 
The general statutory provisions contained in Part 1 of the Status of Children Act 1969 are the most appropriate to determine whether Michael, Scott, and Jeremy are legal fathers. In all three of the above scenarios none of the men were married to the child's mother at the time of conception so the statutory presumption of parenthood does not apply. ${ }^{112}$ Instead, Michael, Scott, and Jeremy can become the child's legal father simply by signing the child's birth certificate or an instrument acknowledging they are the child's legal father jointly with the child's mother. ${ }^{113}$ If Michael, Scott, or Jeremy oppose becoming the child's legal father and refuse to sign the child's birth certificate, the child's mother can apply for a declaration of paternity under s 10 of the Status of Children Act 1969. The application can be made in the High Court or the Family Court. ${ }^{114}$ Alternatively she could apply for a paternity order under the Family Proceedings Act $1980 .^{115}$

A declaration of paternity will be made if the Court is satisfied that the relationship of father and child exists. The Supreme Court has determined that the relationship referred to in s 10 is the legal relationship between the father and child, ${ }^{116}$ and the Act provides that the existence of the relationship must be proven on a balance of probabilities. ${ }^{117}$ In the above scenarios it is clear that Michael, Scott, and Jeremy have a biological relationship with each respective child. The Supreme Court held in Hemmes $v$ Young that while s 10 is not designed to be a vehicle for declaring biological relationships, proof of the fact of a biological relationship will in most cases justify a declaration that the legal relationship of father and child exists. ${ }^{118}$

However, it should be noted that a declaration of paternity will be determined differently depending on whether it is made in the Family Court or the High Court. In the High Court, once the relationship of father and child has been proven on a balance of probabilities the Court has discretion to grant the declaration. In the Family Court, once the relationship has been proven on a balance of probabilities the Court must grant the declaration. In $L v R^{119}$ Judge Whitehead rejected the argument that the High Court and Family Court should have concurrent jurisdiction because of the plain meaning of $\operatorname{si0}(5)(a)$ of the Act, stating that: ${ }^{120}$

\footnotetext{
${ }^{112}$ Status of Children Act 1969, s 5.

${ }^{113}$ Section 8(1)-(2).

${ }^{114}$ Status of Children Act 1969, s 10(5).

${ }^{115}$ Family Proceedings Act 1980, s 51.

${ }^{116}$ Hemmes $v$ Young [2005] NZSC 47.

${ }^{117}$ Status of Children Act 1969, s 10(6).

${ }^{118}$ Hemmes $v$ Young [2005] NZSC 47 at [16].

${ }^{119} L v R$ FC Nelson FAM-2005-042-489, 21 September 2007.

${ }^{120}$ Ibid, at [31].
} 
[31] When an application under s 10 of the Status of Children Act 1969 is made to the High Court, s 10(5)(b) states that the provisions of the Declaratory Judgments Act 1908 apply. The High Court's jurisdiction under that Act is discretionary. When the application is made in the Family Court, s 10(5)(a) directs that the provisions of the Family Proceedings Act 1980 apply. Under the Family Proceedings Act, the Family Court's jurisdiction is not discretionary.

Therefore, if an application is made in the High Court, the Court has discretion to grant the declaration even when a legal relationship has been proven. This leaves a very small window of opportunity for the Court to determine other factors, including the effect of lack of consent or deceit in relation to the child's conception. However, it is very unlikely that a High Court would exercise its discretion and refuse to grant a declaration of paternity (or alternatively grant a declaration of non-paternity) in regards to a biological father who did not consent to the conception of the child or was deceived into becoming a father, unless a very strong argument was made. A test case has not yet arisen in New Zealand.

In conclusion, a male who did not consent to becoming the biological father of a child or was deceived into becoming the biological father of a child is nevertheless the legal father of the child, so long as there is sufficient proof on a balance of probabilities that there is a biological relationship between the male and the child. The circumstances of the child's conception have no impact on whether he is deemed the child's legal father. At one end of the scale, if a male has unprotected sexual intercourse with a female resulting in a child, he is the legal father of the child. At the other end of the scale, if a male has protected sexual intercourse with a female but she took the used condom out of the rubbish and inseminated the discarded semen into herself without his knowledge or consent, the male is the child's legal father. ${ }^{121}$

\section{The main principles supporting the current legal framework}

The current legal framework is firmly based on core principle A:

(A) Legal parenthood is based on a biological relationship between the parent and the child

This is evident due to the fact that if it is proven on a balance of probabilities that there is a biological relationship between the male and the child, a legal relationship of father and child is established.

The framework is also firmly based on principle C:

\footnotetext{
${ }^{121}$ Even if the parties did not have sexual intercourse but engaged in oral sex and the female collected the semen in some manner and inseminated it into herself to conceive a child the male would still be the child's legal father.
} 
(C) There should be certainty about the legal status of children in relation their their parents

In all scenarios involving non-consensual and deceitful natural paternity, the child's biological father always becomes the child's legal father. The circumstances of the child's conception are entirely irrelevant for the purpose of determining legal parenthood. Therefore, there is always certainty about the status of the child in relation to their biological father.

\section{Dissertation argument}

Principle A should remain the core principle in the current legal framework. Accordingly, a male who did not consent to becoming the legal father of a child or was deceived into becoming the legal father of a child should remain the child's legal father. This is because there is no principled basis for an argument that males in such circumstances should not be the child's legal father. Legal parenthood in the current context differs from non-consensual artificial paternity (discussed in the previous chapter) in this regard. In addition, a no exceptions rule that biological parenthood results in legal parenthood, regardless of the circumstances of the child's conception, provides certainty in terms of the child's status in relation to their biological father, in accordance with principle $\mathrm{C}$.

However, there is one partial principled exception to Principle A. Principle (D)(iii) provides that:

D(iii) The circumstances of the child's conception can determine whether the child's biological parent is liable to pay child support

This principle provides a partial exception to principle A because although one aspect of legal parenthood is affected, namely child support liability, for all other purposes the biological parent is still the child's legal parent. Accordingly, the legal provisions in regards to intestacy, ${ }^{122}$ family protection, ${ }^{123}$ and citizenship ${ }^{124}$ still have full force.

Principle D(iii) is reflected in s 89Z of the Child Support Act 1991 and provides that:

\section{$89 \mathrm{Z}$ Grant of exemption to victim of sex offence}

(1) The Commissioner must, as soon as practicable after receiving an application under section $89 \mathrm{Y}$ in respect of a liable parent and a particular child, exempt the person from the payment of child support in relation to that child if-

(a) the application is made in accordance with that section; and

(b) the Commissioner is satisfied that the liable parent is a victim of a sex offence; and

(c) the Commissioner is satisfied that either-

\footnotetext{
${ }^{122}$ Administration Act 1969, s 77.

${ }^{123}$ Family Protection Act 1955, s 3.

${ }^{124}$ Citizenship Act 1977, s 3.
} 
(i) another person has been convicted of that sex offence; or

(ii) another person has been proved to have committed that sex offence before a Youth Court; and

(d) in the opinion of the Commissioner, it is likely that the child was conceived as a result of that sex offence.

This provision was inserted into the Child Support Act 1991 by the Child Support Amendment Bill 2005. Hansard records show that Parliament formulated the provision with underage victims in mind, particularly underage boys who father children to older women. However, it is not a requirement that the victim be an underage victim when the sex offence occurred, instead 'sex offence' for the purposes of the section has a wide definition and means any offence under ss 127 to $144 \mathrm{C}$ of the Crimes Act $1961 .^{125}$ It is a requirement that the sex offence is the subject of a conviction. Accordingly, an alleged sex offence will not provide grounds for an exemption. $^{126}$

Section $89 \mathrm{Z}$ is significant as it is the only provision in the Child Support Act 1991 that fully exempts a biological parent from paying child support. Hansard records show that Parliament provided two rationales for this exemption. Firstly, the imposition of child support liability on victims of sex offences is unjust, and secondly, victims of sex offences should not be further victimised by being required to pay child support. ${ }^{127}$ These two rationales were regarded by Parliament as significant enough to override two of the main purposes of the Act: to affirm the right of children to be maintained by their parents, and the corresponding obligation of parents to maintain their children. ${ }^{128}$

Applying these two rationales to cases of non-consensual natural paternity and deceitful natural paternity, it could be argued that if both rationales can be met, the biological father should be exempt from paying child support.

\section{Non-consensual natural paternity}

In scenarios involving non-consensual natural paternity, the biological mother and father had consensual sexual intercourse that resulted in the unplanned conception of the child. The conception of the child may have resulted from a lack of contraception, faulty contraception, or miscommunication regarding contraception.

\footnotetext{
${ }^{125}$ Child Support Act 1991, s 89Y(2).

${ }^{126}$ WJCR v Commissioner of Inland Revenue FC North Shore FAM-2009-044-1319, 12 October 2009.

${ }^{127}$ (24 November 2005) 628 NZPD 503.

${ }^{128}$ Child Support Act 1991, s 5(a)-(b).
} 
In such scenarios the father of the child may not object to child support liability. However, he may object in certain circumstances if he believes he made it clear to the child's mother that he did not want to have children before entering into a sexual relationship with her, if he disagrees with her decision to keep the child and not opt for an abortion or adoption, or if he believes the child's conception was a result of her negligence.

(i) Rationale 1: Is it unjust to require a male to pay child support if he did not consent to becoming the child's legal father?

It is argued that in scenarios where no contraception was used, it not unjust that the child's biological father is liable to pay child support. This is for the simple reason that he consented to unprotected sexual intercourse, and as the conception of a child is a natural and foreseeable consequence of unprotected sexual intercourse, he has effectively consented to the conception of the child and thus child support liability. In cases where contraception has been used but for some reason was faulty, there is also a strong argument that child support liability is not unjust. This is because contraception is not $100 \%$ effective so when a person consents to sexual intercourse they are also consenting to the risk of conceiving a child and thus child support liability. In addition, where there has been miscommunication regarding contraception both parties will have been negligent in some way.

The main legal argument why it is not unjust that the child's biological father is liable to pay child support is because the biological mother and father of an unplanned child both have an equal statutory obligation to maintain the child under the Child Support Act 1991 as legal parents. ${ }^{129}$ The Act does not discriminate on the grounds of gender.

However, there is one major counter argument that has arisen in recent years from the growing discourse on males' reproductive rights. Namely, it is unjust that males have to pay child support for unplanned children because females have the ability to opt out of being the legal parent of an unplanned child (and thus child support liability) whereas males do not. In addition, upon the conception of an unplanned child, it is solely the female's decision, whether it be to have an abortion, to give the child up for adoption, or to keep the child, that will determine whether the male becomes the child's legal father and thus liable to pay child support.

When an unplanned child is conceived the post-conception reproductive choices for males and females are very different. A female has three choices. Firstly, she can have an abortion in accordance with the Contraception, Sterilisation, and Abortion Act

${ }^{129}$ Section 6(1)(a). 
1977; secondly, she can give the child up for adoption in accordance with the Adoption Act 1955; and finally, she can keep the child.

In contrast, a male has no post-conception reproductive choice as the female's decision will determine whether he becomes a legal parent and thus liable to pay child support. It has been argued that a male should have a legal right to be notified and consulted about decisions relating to abortion and adoption, ${ }^{130}$ or that a male should be able to veto a female's decision if he disagrees with it. ${ }^{131}$ This dissertation does not agree with either of these propositions because the law on abortion and adoption is well established and allowing males to influence or veto female's choices would fundamentally infringe upon female's post-conception reproductive choices. It could result in scenarios where females are forced to have an abortion, give their child up for adoption, or endure an unwanted pregnancy and raise a child against their will. Therefore, males should not have post conception reproductive choice in regards to abortion and adoption.

However, it has been argued that males should have a post-conception reproductive choice if a female decides the keep the child. This choice could take the form of a 'financial abortion,' a concept proposed by Brown University Professor Frances Goldscheider. ${ }^{132}$ Brown describes a 'financial abortion' as the right to be notified about the conception of the child and to decide whether to undertake the legal rights and responsibilities of parenthood or not. She notes that such a decision would have to be made in a short window of time, and once the male has decided to have a financial abortion (or not), he is legally bound by his decision. Therefore, males would not be able to subsequently opt out of child support obligations they had previously committed to. Brown argues that the inequality between males and females in regards to reproductive choice needs to be addressed, commenting in an interview: ${ }^{133}$

While I thought I was a feminist all my life, when I started studying the family and fatherhood in general, I realized that I was really an egalitarian. I want a level playing field in the family for men and women.

\footnotetext{
${ }^{130}$ See for example Planned Parenthood of Southeastern Pennsylvania v Casey, 505 U.S. 833 (1992) in which the United States Supreme Court held that a male has no right to be notified or informed about a female's decision to have an abortion.

${ }^{131}$ See for example $C v S$ [1988] QB 135 in which the English Court of Appeal held that a male cannot veto a female's decision to have an abortion.

${ }^{132}$ Frances Goldscheider "Men, Children and the Future of the Family in the third Millennium" (2000)

32 Futures, 527-538.

${ }^{133}$ Cord Jefferson (6 July, 2010) "What if I don’t want to be a daddy?" < www.theroot.com>
} 
The right to a 'financial abortion' was explored in the American case of Dubay $v$ Wells and Attorney General. ${ }^{134}$ The case sparked intense media interest and debate on males' reproductive rights ${ }^{135}$ and was dubbed the male equivalent of the landmark judgment Roe v Wade ${ }^{136}$ which legalised abortion in the United States in 1973. The case concerned two university students who disagreed over their rights and responsibilities towards an unplanned child that was conceived as a result of their consensual sexual relationship. When the plaintiff, Matt Dubay, began dating the defendant, Lauren Wells, he claimed he made it clear that he was not ready to have children and wanted to take proper precautions to avoid an unplanned pregnancy. In response, Wells told him that she was probably infertile due to a medical condition and that as an extra layer of protection she was taking the contraceptive pill. The couple dated for several months then separated. Subsequently, Wells discovered that she was pregnant and decided to keep the child. Once the child was born she sued Dubay for child support. He objected and applied for a Court declaration that the Michigan Paternity Act $^{137}$ and related statutes were unconstitutional, arguing that the Act violates the Equal Protection Clause of the Fourteenth Amendment which guarantees that no one state shall deny to any person within its jurisdiction the equal protection of the laws.

Dubay argued that the Act denied him the equal protection of the laws in two ways. Firstly, he argued that the Act denied him the equal protection of the laws by affording females a right to reject motherhood after engaging in consensual sexual intercourse by allowing the right to abortion while denying an equivalent right to males. Secondly, he argued that under the safe haven and abandonment laws in Michigan, ${ }^{138}$ a female has the right to unilaterally drop off a newborn at the hospital, police department, or clinic without any legal or financial recourse whatsoever, a right not afforded to males. In addition, he argued it is easier for a female to place a child for adoption, and again avoid being forced into unwanted parenthood.

On appeal the Court upheld the decision of the trial judge and rejected Dubay's claim on the basis that it is not a fundamental right of any parent, male or female, to sever financial responsibilities to their child after the child is born. ${ }^{139}$ In addition, the Court held that Dubay's claim that a male's right to reject fatherhood is analogous to a female's right to abortion rests upon a false analogy because when a female exercises

\footnotetext{
${ }^{134}$ Dubay $v$ Wells and Attorney General 6 F.3d 422 (6th Cir, 2007).

${ }^{135}$ See for example "US Men challenge child support laws" (9 March 2006) <www.bbc.co.uk> and Nancy Gibbs “A man's right to choose?” (15 March 2006) <www.time.com>

${ }^{136}$ Roe v Wade, 410 U.S. 113 (1973).

${ }^{137}$ Michigan Paternity Act, Mich. Comp. Laws $§ 722.711$ (2002).

${ }^{138}$ Safe Delivery of Newborns Act, Mich. Comp. Laws $\$ \S 712.1-712.20$ (2002).

${ }^{139}$ Dubay $v$ Wells and Attorney General 6 F.3d 422 (6th Cir, 2007) at 5.
} 
her right to abortion, the pregnancy does not result in a live birth and there remains no child for the state to have an interest in supporting through child support. In the case of a male seeking to opt out of fatherhood and thereby avoid child support obligations, the child is already in existence and the state therefore has an important interest in providing for his or her support. ${ }^{140}$ In addition, the Court held that a female's right to abortion is not solely, or even primarily, based upon her right to choose to be a mother after engaging in consensual sexual intercourse. Rather, it derives from the female's right to bodily integrity and her privacy interest in protecting her own physical and mental health. ${ }^{141}$

The Court rejected Dubay's second argument stating that the safe haven and abandonment laws and the adoption laws in Michigan are gender neutral and are rationally related to a legitimate Government interest, ${ }^{142}$ therefore they were not enacted with a discriminatory intent or for a discriminatory purpose. ${ }^{143}$ Finally, and most importantly, the Court noted that Michigan paternity Act does not discriminate on the basis of gender and clearly stipulates that both parents have an equal obligation to maintain their child. ${ }^{144}$ After the judgment was delivered Dubay was asked by National Center for Men to appeal to the Supreme Court but he declined. ${ }^{145}$

As Time magazine reported: ${ }^{146}$

Dubay $v$ Wells was a legal stunt, but as a way of calling attention to double standards and unintended consequences, the campaign makes sense.

Indeed, the larger legal and certainly philosophical questions arising from the case are: should the different biological roles males and females play in reproduction solely determine their legal options? Is it inequitable that males have no legal options in regards to reproduction? Or are questions of equality not applicable in the context of reproduction? While outside the scope of this dissertation, ongoing consideration of these questions is needed because reproduction is fundamental to both males and females. As societal attitudes change, so too may the answers to these questions.

However, for the present purposes, the main consideration is whether it is unjust to require a biological father to pay child support if he did not consent to becoming the child's legal father. It is argued that because both male and female legal parents have equal statutory obligations under the Child Support Act 1991 to maintain their

\footnotetext{
${ }^{140}$ Kulko v Superior Court of California, 436 U.S. 84, 98 (1978).

${ }^{141}$ Roe v Wade, 410 U.S. 113 (1973).

${ }^{142}$ Clark v Jeter 486 U.S. 456 (1988) at 461.

${ }^{143}$ Bennett v City of Eastpointe, 410 F.3d 810, 818 (6th Cir. 2005).

${ }^{144}$ Dubay v Wells and Attorney General 6 F.3d 422 (6th Cir. 2007) at 5.

${ }^{145}$ Nancy Gibbs “A man's right to choose?" (15 March 2006) <www.time.com>

${ }^{146}$ Ibid.
} 
biological children the answer must be no. The respective reproductive options of males and females are different prior to becoming legal parents but once both have acquired that legal status their obligations are identical. Therefore, if the legal father of an unplanned child is the non-custodial parent under the Act and the child's legal mother is the custodian parent, the legal father is liable to pay child support to her. In the reverse situation where the legal father of an unplanned child is the custodian parent, the child's legal mother is equally liable to pay child support to him. As in Dubay $v$ Wells, the Act does not discriminate, in this respect, on the grounds of gender.

(ii) Rationale 2: Is a male who became a legal father without his consent a victim who should not be further victimised by having to pay child support?

In cases of non-consensual natural paternity, there has been no deceitful conduct to bring about the conception of the child so the male is therefore not a victim. Instead, the conception of the child was simply accidental and essentially resulted from the negligence of the male, female or both.

In conclusion, as neither rationale 1 or 2 has been met, a partial exception to principle A by way of principle $\mathrm{D}$ (iii) is not justified in cases of non-consensual natural paternity. Therefore, biological fathers who do not consent to becoming legal fathers should remain liable to pay child support.

\section{Deceitful natural paternity}

Deceitful natural paternity results from consensual sexual intercourse or sexual activity and a deliberate deceitful act by the biological mother that resulted in the conception of the child. As in cases of non-consensual natural paternity, the father of the child may not object to child support liability. However, the father may object in certain circumstances on the grounds that the mother made a deliberate misrepresentation about contraception or fertility, or because he attempted to use contraception but the mother deliberately caused it to be ineffective. Alternatively he may object on the ground that the mother carried out a deliberate premeditated act independent of sexual intercourse to bring about the conception of the child.

(i) Rationale 1: Is it unjust to require a male to pay child support if he was deceived into becoming the child's legal father?

In scenarios where the child's mother lied about taking the contraceptive pill, deliberately stopped taking the contraceptive pill, or lied about being infertile (and 
therefore no condom was used) one could argue it is not unjust that the male pay child support because he could have used a condom to prevent the conception of the child. Essentially it is up to him to use his own form of contraception and he cannot place the responsibility to prevent the conception of the child solely on the child's mother. However, if the parties had an agreement that she take the contraceptive pill, it could be argued that she had an obligation to inform him when she stopped taking it.

In scenarios where the child's mother tampered with contraception, namely she pricked the condom before it was used, there is perhaps a stronger argument that child support liability is unjust. This is because the male has used a condom to prevent the conception of the child but the child's mother deliberately made the condom ineffective to prevent the conception of the child.

Finally, in scenarios where the conception of the child has resulted from semen being removed from a condom and subsequently inseminated there is perhaps an even stronger argument that child support liability is unjust. This is because the conception of the child has not resulted from sexual intercourse, which both parties consented to, but a separate deliberate act which the male did not consent to or was even aware had taken place. Where semen has been collected in the course of oral sex and subsequently inseminated, child support liability could also be regarded as substantially unjust as the conception of a child was not a natural or foreseeable consequence.

While the various scenarios involving deceitful paternity are different with the resulting child support liability perhaps more unjust in some than others, there is a common thread that runs through all of the scenarios. Namely, while the male consented to the sexual activity, one could argue his consent has been vitiated due to the mother's deceit. Therefore, the sexual activity was non-consensual.

Lack of consent to sexual activity is a common thread through most sexual offences. While Parliament did not specifically discuss why it is unjust for victims of sex offences to be liable to pay child support, it is arguably because victims of sex offences did not consent to the sexual activity which resulted in the conception of the child. Therefore, they should not be liable for the financial consequences that flow from the conception of the child. On that basis, it is necessary to determine whether a deceived father did not consent to the sexual activity which resulted in the conception of the child. If he did not, he should perhaps not be liable for the financial consequences that flow from the conception of the child. 
Lack of consent to sexual activity has been thoroughly explored in the context of criminal law. In some circumstances it will be clear that the sexual activity was nonconsensual, although in circumstances where the victim has allowed the sexual activity, it may be less clear whether it was non-consensual. Section 128A of the Crimes Act 1961 provides a list of specific circumstances in which allowing sexual activity does not amount to consent. For example, a person does not consent to sexual activity if they are: affected by alcohol or drugs, affected by an intellectual, mental, or physical condition, mistaken about who the other person is, asleep, or unconscious. In addition, a person is not assumed to have consented because they did not protest or offer physical resistance to the activity.

Two subsections of s $128 \mathrm{~A}$ can be analysed in the context of deceitful paternity to determine whether the sexual activity which resulted in the conception of the child was non-consensual. Section 128A(7) provides that a person does not consent to an act of sexual activity if he or she allows the act because he or she is mistaken about its nature and quality. Section $128 \mathrm{~A}(8)$ provides that $\mathrm{s} 128 \mathrm{~A}$ does not limit the circumstances in which a person does not consent to sexual activity. Accordingly, the common law requirement that consent must be informed consent falls under s $128 \mathrm{~A}(8) .{ }^{147}$

Sections $128 \mathrm{~A}(7)$ and $128 \mathrm{~A}(8)$ are the most appropriate sections to determine whether the sexual activity in cases of deceitful paternity is non-consensual because they were recently interpreted by the Court of Appeal in arguably the most analogous context to deceitful paternity. Cases involving non-disclosure of HIV positive status between consenting sexual partners are arguably analogous because both involve two sexual partners who consented to sexual activity, and a failure by one to disclose important information which had significant consequences for the uniformed party, namely, HIV infection ${ }^{148}$ or the conception of a child.

In KSB $v$ Accident Compensation Corporation ${ }^{149}$ the Court of Appeal held that if a person fails to disclose their HIV status to a consenting sexual partner and engages in unprotected sexual activity with that partner, their conduct amounts to sexual violation for the purposes of a claim under ACC. The applicant in $K S B$ did not consent to the sexual activity because she was mistaken about the nature and quality of the act (in accordance with s 128A(7)) and had not given full and informed consent (in accordance with s $128 \mathrm{~A}(8)$ ).

\footnotetext{
${ }^{147}$ KSB v Accident Compensation Corporation [2012] NZCA 82.

${ }^{148}$ Or the risk of infection.

${ }^{149}$ Ibid.
} 
In determining whether the failure of the claimant's partner to disclose his HIV status amounted to the definition of sexual violation, the Court of Appeal noted that apart from the Canadian Supreme Court judgment of $R v$ Cuerrier, ${ }^{150}$ common law jurisdictions had not yet recognised that a failure to disclose HIV status can vitiate consent in regards to rape or other sexual offences. In addition, the issue had not been fully explored and tested in New Zealand criminal law, as previously such conduct had only resulted in a conviction of criminal nuisance under s 145 of the Crimes Act $1961 .^{151}$

The first question the Court of Appeal considered was whether the complainant had been mistaken as to the "nature and quality" of the sexual activity she had consented to. It was noted that courts in England and Australia had taken a narrow approach and held that the mistake in cases of potential HIV infection is not about the nature and quality of the act (namely sexual intercourse) but rather its consequences (the risk of infection or harm). ${ }^{152}$ However, the Court of Appeal preferred a wide interpretation of s 128A(7) and considered that a mistake as to the "nature and quality" is not limited solely to a mistake about the physical act, it can also include the consequences flowing from the act. Following $R v$ Cuerrier, which used a commercial definition of fraud in its reasoning, the Court held that unprotected sexual intercourse with a person who has not disclosed his or her HIV status changes the nature and quality of the act because of the associated risk of serious harm. ${ }^{153}$

This leads to the question of what constitutes an "associated risk of serious harm" as it is a mistake about this risk which changes the nature and quality of the act. In $K S B$, the risk of serious harm was the risk of serious physical harm to the claimant's health resulting from HIV infection. ${ }^{154}$ In cases of deceitful paternity, there is no risk of serious physical harm. However, there is arguably not only the risk of but actual serious harm of another nature, namely financial and psychological harm resulting from the conception of the child. The financial harm is 18 years of child support liability amounting to approximately $\$ 125,000,{ }^{155}$ and the psychological harm will in the very least be considerable distress, but could also take the form of depression or another recognised mental injury.

\footnotetext{
${ }^{150} R v$ Cuerrier [1998] 2 SCR 371.

${ }^{151}$ See for example $R v$ Mwai [1995] 3 NZLR 149.

${ }^{152}$ Bruce Robertson (ed) Adams on Criminal Law (2011 student ed, Brookers) at [CA128A].

${ }^{153}$ KSB v Accident Compensation Corporation [2012] NZCA 82 at [74].

${ }^{154}$ It is not a requirement that the person actually contract HIV, merely that they are exposed to the risk of contracting it.

155 This figure is based on the estimated cost of raising a child in New Zealand provided by Inland Revenue (\$250,000 over 18 years) see Supporting children: A Government discussion document on updating the child support scheme (Inland Revenue, September 2010).
} 
Guidance on whether the cost of raising a child could be regarded as harm can be drawn from wrongful birth claims. Such claims have been made by parents who seek to claim damages for the cost of raising an unplanned child who was conceived as the result of a negligent sterilization procedure. In England, the cost of raising a child is not regarded as harm. ${ }^{156}$ In stark contrast, the cost of raising a child is regarded as harm in Australia and accordingly is recoverable. ${ }^{157}$ Furthermore, a recognised mental injury could be accurately described as harm as it attracts cover under ACC as a personal injury in some circumstances. ${ }^{158}$

It should also be noted that in $R v$ Cuerrier, the Supreme Court of Canada applied the definition of commercial fraud to determine whether deceitful conduct vitiates a person's consent to sexual intercourse under criminal law. The definition provided that fraud is deception, resulting in deprivation. The Court explicitly applied this definition to cases of deceitful paternity, commenting: ${ }^{159}$

The commercial fraud theory of consent offers no principled rationale for allowing some risks to vitiate consent to sex but excluding others. For example, pregnancy may be regarded as a deprivation in some circumstances, as may be the obligation to support a child. It follows that lying about sterility or the effectiveness of birth control may constitute fraud vitiating consent.

However, the Court later qualified this remark by stating that: ${ }^{160}$

The question of whether other categories of fraud could be logically added on the basis that deceit as to them also fundamentally alters the nature of the physical act itself, is better left for another day. It is doubtful that natural consequences, like pregnancy, would qualify, as they are the natural concomitant of the sexual act, and do not fundamentally alter its nature.

It is of note that pregnancy is not regarded as a 'natural consequence' in all legal contexts. For example, pregnancy is regarded as a personal injury when it results from rape or a treatment injury and therefore attracts cover under ACC. In Allenby $v H$ and Others the New Zealand Supreme Court rejected the argument that pregnancy is not a personal injury because it is a natural process, commenting: ${ }^{161}$

I am not persuaded to a different view that a pregnancy is "a natural process" and is necessary for the survival of the human species.... A woman is entitled to choose whether or not to become pregnant. If she does not wish to do so, the consequences of

\footnotetext{
${ }^{156}$ McFarlane v Tayside Health Board [2000] 2 AC 59.

${ }^{157}$ Cattanach v Melchior (2003) 215 CLR 1 (HCA).

${ }^{158}$ Indeed, the claimant in KSB was ultimately granted cover under ACC for post-traumatic stress disorder.

${ }^{159} R v$ Cuerrier [1998] 2 SCR 371 at [47].

${ }^{160}$ Ibid, at [73].

${ }^{161}$ Allenby $v$ H and Others [2012] NZSC 33.
} 
her becoming pregnant are not to be discounted because pregnancy per se is a natural process. A woman who takes steps to avoid a natural consequence of sexual intercourse ought to be regarded as suffering physical injury when those natural consequences follow as a result of medical misadventure.

Overall, while there is an argument that the financial consequences resulting from an unplanned child is 'harm' for the purposes of deceitful paternity, due to the fact that there is conflicting authority in Australia and England and the issue has not been decided in New Zealand, it cannot be concluded that a deceived male's consent to sexual intercourse is clearly vitiated under s 128A(7). In addition, while guidance can be drawn from Cuerrier and Allenby the reasoning does not clearly support an argument that consent is clearly vitiated under s 128(7).

However, there is a strong argument that a deceived male's consent is vitiated under s $128 \mathrm{~A}(8)$ as he has not given informed consent to the act of sexual intercourse or sexual activity which resulted in the conception of the child. In $K S B$, the Court of Appeal accepted the conclusion of Randerson $\mathrm{J}$ in CLM $v$ Accident Compensation Corporation $^{162}$ that the concept of informed consent is well established as part of New Zealand law, and stated that if it had not been possible to decide the case under $\mathrm{s}$ $128 \mathrm{~A}(7):^{163}$

...we would have concluded that the present case fell within s $128 \mathrm{~A}(8)$. That would be consistent with the focus on the need for consent to be informed and the more recent legislative history.

As the claimant in $K S B$ was unaware of the positive HIV status of her partner she was accordingly uninformed as to the very serious risk she was agreeing to, namely the risk of HIV infection.

In scenarios involving deceitful paternity, the male was unaware of the mother's deceit and was accordingly uninformed as to the very serious risk he was agreeing to, namely, the very high risk of the conception of a child. To put it another way, in cases of deceitful paternity the male has given informed consent to protected sexual intercourse, not unprotected sexual intercourse that will almost certainly result in the conception of the child. Similarly, in cases where sperm is collected and subsequently inseminated, it is clear that the male has not given informed consent to the sexual activity which resulted in the conception of the child. On that basis it is argued that the male's consent is clearly vitiated under s $128 \mathrm{~A}(8)$.

\footnotetext{
${ }^{162}$ CLM v Accident Compensation Corporation [2006] 3 NZLR 127 at [71].

${ }^{163}$ KSB v Accident Compensation Corporation [2012] NZCA 82 at [98].
} 
While $K S B$ concerns an issue of criminal law it is important to note that the claimant was not attempting to argue that her former partner had committed sexual violation under the Crimes Act 1961. Rather she was arguing that her former partner's actions constituted sexual violation for the purpose of her claim for cover for mental injury under the Accident Compensation Act 2001. ${ }^{164}$ For her claim to succeed all she needed to prove that non-disclosure of HIV status vitiates consent to sexual intercourse, in other words simply satisfy s $128 \mathrm{~A}(7)$ or s $128 \mathrm{~A}(8)$. The Court stated that it is not necessary for her to establish that her former partner did not believe that she consented to the act of sexual intercourse, and that he had no reasonable grounds for such a belief. This element would need to be satisfied if the case was heard under the Crimes Act 1961. In essence, the Court of Appeal created its own quasi-definition of sexual violation for the purposes of a claim under the Accident Compensation Act 2001 that is less stringent than the criminal definition.

In cases of deceitful paternity the mother's conduct would not amount to the definition of sexual violation under the Crimes Act $1961,{ }^{165}$ although arguably it does meet the $K S B$ definition of sexual violation as consent is vitiated under s $128 \mathrm{~A}(8)$. Because the mother's conduct does not amount to sexual violation under criminal law, a deceived father is not the victim of a sexual offence. Therefore, such fathers should not be entitled to a full exemption of child support in accordance with s $89 \mathrm{Z}$ of the Child Support Act 1991. However, because the mother's conduct amounts to the definition of sexual violation under $K S B$ (which resulted in a successful compensation claim under the Accident Compensation Act 2001) it is argued that child support liability under the Child Support Act 1991 should be affected in some way. Therefore, full child support liability in cases of deceitful paternity is unjust.

(ii) Rationale 2: Is a male who has been deceived into becoming a legal father a victim who should not be further victimised by having to pay child support?

As a deceived father meets the $K S B$ definition of a victim of sexual violation, he is a victim in a legal sense. In a more general sense, he is a victim as he has been inherently deceived by the child's mother who has taken away his ability to determine whether or not to become a biological parent.

Parliament considered that requiring a victim of a sex offence to pay child support would result in on-going victimization as it would force the victim to have an ongoing link and potentially contact with the offender. They would essentially be bound

\footnotetext{
${ }^{164}$ After learning that her former partner was HIV positive, the claimant suffered from post-traumatic stress disorder.

${ }^{165}$ Indeed, it is not argued that deceitful conduct by the mother should attract criminal liability.
} 
to the offender through a statutory obligation for the next 18 years and with each weekly payment they would be repeatedly victimised. Similarly, in cases of deceitful paternity, the deceived father is bound to the child's mother for the next 18 years, and is forced to have an on-going link and potentially contact with her.

\section{E Recommendations}

In light of the analysis in section $\mathrm{D}$, it is argued that both rationales have been met in cases of deceitful paternity. On that basis, males who are deceived into becoming fathers should not be liable to pay child support. However, this conclusion is subject to an important qualification that has been foreshadowed. Under s $89 \mathrm{Z}$ of the Child Support Act 1991, the applicant must be the victim of a sexual offence that resulted in a conviction in order to qualify for a full exemption to child support liability. Furthermore, if the conviction is quashed or set aside, the victim then becomes fully liable to pay child support. These are stringent requirements. To allow deceitful conduct in cases of deceitful paternity (that would not result in a conviction) to result in a full exemption would be inconsistent with this provision. Therefore, a full exemption for a deceived father cannot be justified.

However, it is argued that because the two rationales have been met the Act should recognise that deceit can have an effect on child support liability. At present a legal parent can make an application under the Act for a departure order from the rigid child support formula where the facts are out of the ordinary. ${ }^{166}$ Section 105 provides a number of grounds for such an order. Deceit should be added as an additional ground for departure order so that a deceived father is eligible to apply for a departure order.

The Family Court does not automatically grant departure orders if a ground is proven, instead the Judge is required to consider the individual facts and must be satisfied that the making of an order is just and equitable as regards the child, the qualifying custodian, the liable parent and is "otherwise proper." This flexible approach allows the Court to make an individual determination on the facts which is appropriate in deceitful paternity cases because as previously noted, there is a range of deceitful conduct, with some conduct more deceitful than other conduct. Importantly, the Court will also consider whether the order is just and equitable as regards the child. Essentially, this new ground for a departure order provides a 'middle ground' of sorts for the father and child who are both victims of the mother's deceit.

It addition it is argued that adding deceit as a new ground for a departure order is necessary as it may discourage some women from deceiving men into becoming

\footnotetext{
${ }^{166}$ Child Support Act 1991, ss 104-107.
} 
fathers, and therefore less children will be born into such complicated family circumstances. At present there is no acknowledgement in any family law legislation that deceiving a person into becoming a biological and legal parent is behaviour that should be discouraged. This acknowledgement is necessary because such behaviour has significant psychological, financial and legal consequences for men and children.

Recommendation 1: Insert deception as a ground for a departure order in s 105 of the Child Support Act 1991.

\section{Matters as to which court must be satisfied before making order}

(1) Where an application is made to a Family Court under section 104 for an order in relation to a child and the court is satisfied that-

(a) 1 or more of the grounds for departure mentioned in subsection (2)

exists or exist; and

(b) it would be-

(i) just and equitable as regards the child, the qualifying custodian, and the liable parent; and

(ii) otherwise proper,-

to make a particular order of the type specified in section 106,-

the court may make the order.

(2) For the purposes of subsection (1)(a), the grounds for departure are as follows: (d) deception used by the biological mother of the child to bring about the conception of the child

(e) deception used by the biological father to bring about the conception of the child ${ }^{167}$

\footnotetext{
${ }^{167}$ This equivalent ground is included to ensure that s 105(2)(d) is not discriminatory on the grounds of gender.
} 


\section{Misattributed Paternity}

\section{A Introduction}

So far, this dissertation has focused primarily on determining whether, upon the birth of a child, the biological father of the child becomes the legal father of the child. Analysis of misattributed paternity raises a new set of issues as the legal relationship of parent and child has already been established but has been done so erroneously, as the legal father and the child do not share a biological relationship.

Misattributed paternity is often referred to as "paternity fraud," implying deliberate deceit on the part of the child's mother. However, for the purposes of this dissertation, misattributed paternity means paternity involving the incorrect identification of the child's biological father by the child's mother either mistakenly, recklessly or intentionally. In scenarios involving misattributed paternity, the non-biological father and child are unaware that they do not share a biological relationship until the true paternity of the child is discovered or revealed.

Misattributed paternity can have significant legal consequences for the child as well as the non-biological father, biological father and mother of the child. It can affect inter alia legal parenthood, maintenance, inheritance as well as guardianship and parenting orders relating to the child. Profound practical and psychological consequences can also affect the parties involved. The extent of the consequences resulting from misattributed paternity will largely depend on the length of time the child's paternity has been misattributed.

It is difficult to accurately determine how common misattributed paternity is, although international studies estimate the number of people who have a 'misattributed' father range from 1 to $8 \%,{ }^{168}$ with the common consensus in New Zealand being approximately $1.8 \% .{ }^{169}$ Based on New Zealand's population of approximately $4,430,000$ people, ${ }^{170}$ about 80,000 people may have a 'misattributed' father. Of that 80,000 , approximately 16,000 are children aged 15 and under. This is a considerable number although presumably a very large percentage of both adults and children are unaware that their legal father is not their biological father.

The main issue for consideration in this chapter is whether, upon the discovery of misattributed paternity, the child's non-biological father should remain the child's

\footnotetext{
${ }^{168}$ Craig Lind, Heather Keating Jo Bridgeman (eds) Taking responsibility, law and the changing family (Ashgate Publishing, Burlington, 2011) at 193.

${ }^{169}$ Law Commission New Issues in Legal Parenthood (NZLC R88, 2005) at [4.17].

${ }^{170}$ National Population Estimates: March 2012 quarter (Statistics New Zealand, March 2012).
} 
legal father. This chapter also addresses the legal position of the child's biological father, who may or may not have been aware that he has fathered a child. Subsidiary issues that can arise in scenarios involving misattributed paternity regarding guardianship, parenting orders, child support and parentage testing will also be addressed.

\section{B Under the current New Zealand legal framework, is a male who became the legal father of a child under the misapprehension he was the child's biological father still the legal father of the child?}

To put this question into context, consider the following hypothetical scenarios:

Scenario 1: Simon, 26, and Angela, 25, meet at a friend's party and date for a couple of months. One day, Angela receives a txt from her ex-boyfriend, Tyler, also 25, saying he misses her and wants to get back together. Realising she still has feelings for him, Angela breaks up with Simon and she and Tyler immediately get back together although she does not tell Tyler about Simon. Two months later Angela realizes she is pregnant and assumes Tyler is the father. This comes as a bit of a surprise to Tyler but he accepts responsibility for the child and upon the birth of the child, signs the child's birth certificate. As time passes, their relationship becomes strained and the couple separate a year after the child's birth. Both agree to shared care of the child, with Angela being the primary caregiver. After a year of paying child support, Tyler starts having doubts as to whether he is the child's father as he does not think the child looks like him. He asks Angela if she is certain that he is the child's father and she says she thought he was, but upon telling him about her relationship with Simon admits there is a possibility that Simon is the child's father.

Scenario 2: Justin and Kate, both 42, were married for ten years. Two years into their marriage Kate gave birth to a child and Justin was named as the child's father on the child's birth certificate. However, for the first four years of their marriage Kate had an ongoing extra-marital affair with work colleague named Ben, who is the child's biological father. Kate and Ben are both aware of this fact and agree to keep the child's true parentage a secret as Kate wants to remain with Justin, and Ben is also married and wants to remain with his wife. When the child is eight years old, Justin learns of Kate's affair and the couple separate. Upon their separation Kate also informs Justin that Ben is the child's biological father.

Scenarios involving misattributed paternity are usually very complex and can have a range of legal outcomes. The child's non-biological father may remain the child's legal father after learning he is not the child's biological father if he and the child's 
mother agree on such an arrangement and take no legal action. This is a likely outcome in scenarios where the non-biological father and mother decide to remain in relationship with each other. However, if the relationship breaks down, the nonbiological father may still wish to remain the child's legal father due to the strong attachment to the child as a result of many years of parenting. Alternatively, if the parties agree that the non-biological father should not remain the child's legal father, the information relating to the child's birth can be amended ${ }^{171}$ by a registrar at the Births, Deaths and Marriages Office after the necessary enquiries have been made. ${ }^{172}$

However, if the parties disagree as to whether the non-biological father should remain the child's legal father, the issue will need to be resolved by the Family Court. Different types of proceedings may be filed by the mother and/or the non-biological father depending on the particular circumstances. In addition, the biological father may file proceedings if he is aware that he is the biological father of the particular child.

In scenario one, Tyler, the non-biological father of the child, could apply for a declaration of non-paternity if he objects to remaining the child's legal father. ${ }^{173}$ The application may be opposed by Angela, the child's mother, for several reasons. Firstly, she may genuinely believe that Tyler is the child's biological father. Alternatively, if she knows he is not the child's biological father she may oppose the application in order to continue to obtain child support from him to pay for the cost of raising the child. As she and Tyler had a shared care arrangement, she may want him to have ongoing contact with the child for the child's benefit, and to have someone share the practical responsibility of raising the child. In addition, she may be unwilling or unable to bring proceedings against Simon to establish that he is the father of the child.

In order to be granted a declaration of non-paternity Tyler must prove on a balance of probabilities that the legal relationship of father and child does not exist between himself and the child. As per the Supreme Court in Hemmes $v$ Young, ${ }^{174}$ proof of a biological relationship will usually be sufficient to prove that a legal relationship exists. Therefore, proof of the absence of a biological relationship will usually be sufficient to prove no legal relationship exists. In determining Tyler's application, the

\footnotetext{
${ }^{171}$ Births, Deaths, Marriages, and Relationships Registration Act 1995, s 84.

${ }^{172}$ Section 82

${ }^{173}$ Status of Children Act 1969, s 10(3). Doubt has been expressed about whether a person could apply directly for a declaration of non-paternity based on the wording of s 10, although the Family Court has subsequently considered and approved such direct applications - see most recently LTG-S v LRP [2012] NZFC 463.

${ }^{174}$ Hemmes v Young [2005] NZSC 47.
} 
Court will consider all the available evidence. The child's birth certificate, which has been signed by Tyler, is existing prima facie evidence of paternity. ${ }^{175}$ Tyler and Angela may give evidence and the Court may call any witness whose evidence may be of assistance, ${ }^{176}$ including a lawyer for the child. ${ }^{177}$ The parties and witnesses are discouraged from giving misleading evidence by the Family Proceedings Act 1980 which provides sanctions for the making of false statements that if made on oath would amount to perjury. ${ }^{178}$

It may be difficult for the Court to determine whether Tyler is the child's biological father based on evidence provided by Tyler, Angela and other witnesses, particularly if the evidence provided is unclear, contradictory or misleading. The results of a parentage test may therefore be the only way to conclusively determine if there is a biological relationship between Tyler and the child. The Court could adjourn the proceedings in order for a parentage test to be carried out, and allow time for a report on the results to be compiled and submitted to the Court as evidence. ${ }^{179}$

It is important to note that the Court can only recommend a parentage test. It cannot order a parentage test. ${ }^{180}$ It is likely that Tyler would agree to undergo a parentage test as he needs to prove that there is no biological relationship between himself and the child. However Angela may, as the child's guardian, refuse to allow the child to undergo the test. She may do so if she knows the results will conclusively prove there is no biological relationship between Tyler and the child. Subject to the right of Angela to explain the reasons for her refusal, the Court may draw such inferences from her refusal as appear proper in the circumstances. ${ }^{181}$

If Angela were to refuse, Tyler could apply for the child to be put under the guardianship of the Court, ${ }^{182}$ and seek an order from the Court requiring the child to undergo a parentage test. Such an application will be granted if the Court concludes that it is in the welfare and best interests of the child to have issues concerning his or her paternity resolved. ${ }^{183}$ The Court has often referred to the right of the child to know

\footnotetext{
175 Status of Children Act 1969, s 8(1).

${ }^{176}$ Family Proceedings Act 1980, s 165.

${ }^{177}$ Section 162.

${ }^{178}$ Section 53.

${ }^{179}$ Section 54(1)(a)-(b).

${ }^{180}$ The limited power of the Court was recently noted in Mv Family Court at Waitakere HC Auckland CIV-2010-404-7814, 16 December 2010.

${ }^{181}$ Family Proceedings Act 1980, s 57.

${ }^{182}$ Care of Children Act 2004, s 31.

${ }^{183}$ The first successful application of this nature was granted by the Court of Appeal in $T v S$ [Guardianship] [2005] NZFLR 466 (CA).
} 
his or her parents, ${ }^{184}$ and determined that this right provides the basis for concluding that parentage testing is in the welfare and best interests of the child. ${ }^{185}$ However, applications of this nature are rarely applied for and rarely granted, as they are regarded as a measure of last resort.

In conclusion, the ultimate outcome in scenario one will highly depend on the evidence available to the Court. If Tyler is granted a declaration of non-paternity, the legal relationship of father and child between himself and the child will come to an end. If the Court declines his application based on a lack of evidence, Tyler will remain the child's legal father. It is also possible that Simon may apply for a declaration of paternity if he discovers he is the biological father of the child. Alternatively, Angela could apply for a declaration of paternity or a paternity order in regards to Simon if the Court declares that Tyler is not the child's legal father.

Scenario two is a very different scenario involving misattributed paternity as the child is much older (eight years of age at the time of the proceedings) and has a wellestablished legal and emotional relationship with a man who is not their biological father, namely, Justin. Justin could apply for a declaration of non-paternity if he objects to remaining the child's legal father. The same issues regarding evidence given by the parties and witnesses could arise as previously discussed in regards to scenario one, and the results of a parentage test may or may not be able to be obtained. In addition, as Justin was married to Kate when the child was conceived, he must rebut the statutory presumption that he is the child's legal father. ${ }^{186}$

As in scenario one, the child's mother (Kate) may oppose the application. However, if the Court is satisfied that Justin is not the child's biological father, a declaration of non-paternity will be granted. Even though Justin has been the child's legal father for eight years, his application is not subject to the time limitations, as the Court has jurisdiction to grant a declaration of non-paternity at any point in the child's life and even after the father, child or both have died. ${ }^{187}$ The Court has also rejected the argument that a non-biological father is estopped from applying for a declaration of non-paternity on the basis that he became aware that he was not the child's biological father but nevertheless continued in the role of legal father for some time after. ${ }^{188}$ Therefore, if Justin became aware of Kate's affair and the fact that Ben is the child's

\footnotetext{
${ }^{184}$ See Article 7 of the United Nations Convention on the Rights of the Child.

185 See T v S [Guardianship] [2005] NZFLR 466 (CA) and more recently Fletcher v Blackburn [Guardianship] [2009] NZFLR 354 (HC).

${ }^{186}$ Status of Children Act 1969, s 5.

${ }^{187}$ Section 10(3).

${ }^{188} T G-S v L R P$ [2012] NZFC 463, at [24].
} 
biological father but did not apply for a declaration of non-paternity for some time, Kate could not argue that he is estopped from applying because he his mind. Kate could argue that because Justin and the child have a strong psychological bond that should form the basis of a legal relationship of father and child. The significance of the concept of 'psychological parenthood' has been recognized by the Court but only in regards to parenting orders, not legal parenthood itself. ${ }^{189}$

Alternatively Kate could apply for a declaration of non-paternity upon her separation from Justin. This could occur if the parties have an acrimonious separation and Kate wishes to cut all ties with him. Such a course of action may be more likely to occur if she subsequently forms a stable relationship with Ben and they both plan on raising the child together. If Justin opposes the application because he wishes to remain the child's legal father, he could argue that psychological bond between himself and the child should form the basis of a legal relationship. However, as previously discussed, such an argument has not yet been accepted by the Court. If the application was made in the High Court, the Court could exercise its jurisdiction and refuse to grant Kate a declaration of non-paternity despite the absence of a biological relationship, although this outcome is unlikely and no test case has arisen on this point.

Once it has been established that the child's non-biological father is no longer the child's legal father, he is no longer a "parent" for the purposes of the Child Support Act $1991^{190}$ and accordingly, no longer liable to pay child support. ${ }^{191}$ Therefore, in scenario one and two, Tyler and Justin would no longer be liable to pay child support. There is also a provision in the Act that allows a previously liable parent to apply to the Court for a refund of child support from the custodian parent. ${ }^{192}$ As Tyler had previously paid child support he could attempt to recover it from Angela and if Justin paid child support to Kate after their separation, he could also attempt to recover it from her. However, the Court only allows child support to be recovered if it is "just and equitable for the purpose of adjusting or giving effect to the rights of the parties and, where appropriate, the child concerned."193

A declaration of non-paternity not only affects child support, but also inheritance. Notably, the child will no longer be entitled to pursue a claim under the Family Protection Act 1955 or on intestacy under the Administration Act 1969.

\footnotetext{
${ }^{189}$ Tanner v Edghill [2008] NZFLR 262 (HC).

${ }^{190}$ Child Support Act 1991, s 7(1).

${ }^{191}$ Ewens v Director General of Social Welfare (1992) 9 FRNZ 371.

192 Child Support Act 1991, s 207(1).

${ }^{193}$ Section 207(2).
} 
Scenarios involving misattributed paternity may result in mixed feelings for the nonbiological father. In scenario one and two, Tyler and Justin may wish to remain actively involved in the child's life or to have some ongoing contact with the child. After a declaration of non-paternity has been made by the Court, the non-biological father could apply to be appointed a legal guardian of the child, ${ }^{194}$ or apply for a parenting order. ${ }^{195}$ The success of such applications will turn on what the Court considers to be in the welfare and best interests of the child. They are perhaps more likely to be applied for and granted in scenarios similar to scenario two as opposed to scenario one, as the child and non-biological father are likely to have a strong psychological relationship and regard each other as family despite the absence of a biological relationship. ${ }^{196}$ If Justin and Kate had other children during their marriage, who were Justin's biological children, the Court may be more likely to approve a guardianship application or grant a parenting order as disrupting the child's relationship with Justin may be very confusing and unsettling for the child as their siblings will still have contact with him. ${ }^{197}$ Angela or Kate may oppose such applications for various reasons, although opposition by the child's mother (and perhaps the biological father) has not been regarded by the Court as determinative. ${ }^{198}$

Finally, if in scenario one Simon became aware that he is the father of Angela's child he may apply for a parenting order or apply to be appointed a guardian of the child. Similarly, if Ben wishes to take on a parenting role he could also apply for guardianship or a parenting order.

\section{The main principles supporting the current legal framework}

The current legal framework is firmly based on principle A:

(A) Legal parenthood is based on a biological relationship between the parent and the child

This is evident as once it has been proven on a balance of probabilities that there is no biological relationship between the non-biological father and the child, the legal relationship of parent and child comes to an end as a result of a declaration of nonpaternity in accordance with principle $\mathrm{D}(\mathrm{ii})$ :

(D)(ii) Proof of an error (resulting from deceit or mistake) regarding the existence of a biological relationship between the legal parent and the child will end the legal relationship of parent and child

\footnotetext{
${ }^{194}$ Care of Children Act 2004, s 27.

195 Section 47.

${ }^{196}$ See Rowlands (formerly McLean) and Rowlands $v$ McLean (1989) 2 FLB and more recently MLF $v$ HJF FC Tauranga FAM-2005-070-1287, 1 July 2008.

${ }^{197}$ MLF v HJF FC Tauranga FAM-2005-070-1287, 1 July 2008.

${ }^{198}$ See Rowlands (formerly McLean) and Rowlands $v$ McLean (1989) 2 FLB and more recently MLF $v$ HJF FC Tauranga FAM-2005-070-1287, 1 July 2008.
} 
The circumstances surrounding the incorrect identification of the child's biological father by the child's mother, the length of time the non-biological father has been the child's legal father, and the strength of the emotional relationship between the nonbiological father and child is irrelevant in terms of determining whether he should remain the child's legal father.

Strict adherence to Principle A and D(ii) provides certainty in terms of the child's legal status in regards to their biological and non-biological father in accordance with principle $\mathrm{C}$ as it provides a no exceptions rule. Namely, if there is no biological relationship between the legal father and the child, the legal relationship can be severed, and if a biological relationship between another man and the child is proven, a legal relationship can be created.

Finally, while the Court does not have the power to order a parentage test, it can require a child to undergo a parentage test if the child is placed under the guardianship of the Court. This outcome upholds principle $\mathrm{F}$ which provides that:

(F) Children should be able to access information about their genetic origins

\section{Dissertation argument}

Principle A should remain the core principle in the current legal framework, supplemented by principle $\mathrm{D}$ (ii). This is because adherence to these principles is necessary in order to provide certainty in terms of the child's legal status in regards to their biological and non biological father, in accordance with principle C. If legal parenthood in cases of misattributed paternity was decided on a case by case basis, and principles $\mathrm{A}$ and $\mathrm{D}$ (ii) were applied in an inconsistent manner depending on the particular facts of the case, this would result in uncertainty for the parties involved and inconsistent outcomes. In addition, the inconsistent application of principle A would result in a double standard where a non-biological father has the same legal responsibility towards a child as a biological father.

Strict adherence to principle A, D(ii) and C may, depending on the particular circumstances, result in legal outcomes which may be considered contrary to the child's welfare and best interests. For example, as a result of a declaration of nonpaternity, the child will only have one legal parent. ${ }^{199}$ This may be regarded as contrary to the child's welfare and best interests as the child will only have one legal parent to provide them with financial support, and contact with a person whom they regard as their father may be cut off. However, as previously discussed earlier in this dissertation, the welfare and best interests of the child is not a relevant principle in

\footnotetext{
${ }^{199}$ Unless the child's biological parent is identified and subsequently becomes the child's legal parent.
} 
regards to determining legal parenthood. Therefore, there is no principled basis for arguing that the welfare and best interests of the child should determine whether a child's non-biological father should remain the child's legal father. This principle is only relevant in cases of misattributed paternity in regards to applications for guardianship, parenting orders, and determining whether a child should undergo a parentage test. Indeed, appointing the non-biological father a guardian of the child or granting a parenting order allowing the non-biological father contact with the child can mitigate some of the consequences flowing from misattributed paternity as both parties can continue to have a relationship.

One could argue that in cases where the non-biological father and child have a wellestablished psychological relationship there should not be strict adherence to principle A, and like adoption, misattributed paternity should provide an exception to principle A. In other words the law should recognise a second instance where the child can have a legal relationship of parent and child with a person whom they do not share a biological relationship.

A male who has adopted a child is similar to a misattributed father in some respects. Neither has a biological relationship with the child although both have a legal relationship of father and child. However, there is one major difference. A male who has adopted a child has consensually entered into the legal relationship with the child fully aware that he has no biological relationship with the child. In contrast, a misattributed father has consensually entered into a legal relationship with the child fully unaware that he does not have a biological relationship with the child.

As adoption and misattributed paternity are not entirely analogous, it would be difficult to justify that misattributed paternity should also provide an exception to principle A. In addition adoption usually requires the consent of the child's biological mother which could be an issue in cases of misattributed paternity where the relationship between the parties has broken down.

It is also of note that there are several procedural or technical aspects of the provisions relating to declarations of non-paternity and non-paternity orders that could be fixed. At present a male is unable to apply directly to the Court for a declaration of nonpaternity under the Status of Children Act 1969, nor for an order declaring that he is not the father of the child under the Family Proceedings Act $1980 .{ }^{200}$ Under both Acts, the Court can only make such a declaration or order on its own initiative, or on an application for the purpose by a party to current proceedings. ${ }^{201}$ In cases of

\footnotetext{
${ }^{200}$ In addition, at present there is not even provision for a father to apply for a paternity order.

${ }^{201}$ Status of Children Act 1969, s 10 and Family Proceedings Act 1980, s 47.
} 
misattributed paternity, the paternity of the child has already been established so proceedings for a declaration of paternity or paternity order will not take place. Therefore, the non-biological father technically cannot bring proceedings to establish that he is not the father of the child. While the Family Court has accepted direct applications for declarations of non-paternity on a strained interpretation of the $\mathrm{s} 10$ of the Status of Children Act, ${ }^{202}$ the wording of the section should be amended because it is inequitable that an application cannot be made directly by a male who is not the biological father of the child but can be made by the mother of the child. The provisions regarding applications for paternity orders should also be amended so that they are consistent with the provisions regarding declarations of paternity. Further explanation of the wording that should be used is provided in section five of this chapter.

A further procedural issue is that in deciding declarations of non-paternity the Court has different jurisdiction depending on which Court the application was lodged. In the High Court, once the relationship of father and child has been established on a balance of probabilities, the Court has discretion to grant the declaration. In the Family Court, once the relationship has been established on the balance of probabilities, the Court must grant the declaration. It is argued that both courts should have the same jurisdiction when granting declarations of paternity (and non-paternity) as this removes any inconsistency in outcomes that could occur.

Finally, while no substantive changes should be made to the current legal framework used to determine legal parenthood in cases of misattributed paternity, principle $\mathrm{F}$ should be given greater weight in the provisions concerning parentage testing. This is because children born as a result of an AHR procedure have a statutory right to access information about their genetic origins, whereas a present naturally conceived children have no statutory right to access information about their genetic origins. This inconsistency needs to be corrected as it is equally important that naturally conceived children know their genetic origins, particularly if they are in doubt. Furthermore, s 5(f) of the Care of Children Act 2004, which provides that a child's identity should be preserved and strengthened, arguably indicates that it is in the welfare and best interests of children to know their genetic origins, as they are a key aspect of the child's identity.

${ }^{202}$ See for example $L T G-S v L R P$ [2012] NZFC 463. 


\section{$1 \quad$ Parentage testing}

The Law Commission highlighted parentage testing as an issue of concern in the report New Issues in Legal Parenthood, published in $2005 .{ }^{203}$ The Commission considered various issues under three main headings: the regulation of parentage testing in New Zealand; voluntary parentage testing; and Court intervention. In regards to Court intervention the Commission considered three options for recommendation. Firstly, the Court could continue to have the power to recommend parentage testing and to draw an inference when there is refusal to comply. Secondly, the Court could be empowered to order parentage testing and retain the ability to draw an inference as the only sanction if the order is resisted. Thirdly, the Court could be empowered to order parentage testing backed up by a range of possible orders to ensure compliance and the ability to impose penalties.

After careful analysis the Commission chose to recommend option three. ${ }^{204}$ In doing So it commented: ${ }^{205}$

It is in the best interests of the child, his or her parents and the general public that parentage determinations are made on the basis of accurate DNA parentage testing. Without this, determining parentage may be a difficult task and result in lengthy and expensive court proceedings. The Court may have to rely on legal presumptions and inferences, and the determination will not necessarily end speculation and rumour on the issue.

The Commission noted that the Family Court had recently, for the first time, ordered a parentage test upon placing the child under the guardianship of the Court. ${ }^{206}$ While the Court was faced with conflicting precedents and a lack of statutory authority, the parentage test was ordered on the basis that the Court was obliged to apply the provisions of the Guardianship Act 1968 in a manner that was consistent with the articles in UNCROC that refer to a child's right to know his or her parents. The Commission endorsed the approach taken by the Court and recommended that it be given statutory authority to order parentage tests to give better effect to New Zealand's international obligations under UNCROC to enable children to know their parents and genetic identity. ${ }^{207}$

\footnotetext{
${ }^{203}$ Law Commission New Issues in Legal Parenthood (NZLC R88, 2005).

${ }^{204}$ Ibid, at [6.65].

${ }^{205} \mathrm{Ibid}$, at [5.63].

${ }^{206} T$ v S [Guardianship] [2005] NZFLR 466 (CA).

${ }^{207}$ Law Commission New Issues in Legal Parenthood (NZLC R88, 2005) at [5.65].
} 
In addition to the ability to order parentage tests, the Commission considered the consequences of non-compliance with an order and proposed that there be sanctions for non-compliance, commenting: ${ }^{208}$

While a punitive approach is not in harmony with the general ethos of family law to facilitate relationships, the persistent refusal of some people to comply in good faith with court directions can have serious consequences for the children and other parties involved.

As Parliament had recently considered incentives and penalties to ensure compliance with court directions in passing the Care of Children Act 2004, the Commission recommended sanctions for non-compliance with a parentage testing order made under the Family Proceedings Act 1980 should align with the relevant provisions of the Care of Children Act 2004. It noted that if issues regarding the compliance of certain orders cannot be resolved by counselling, ${ }^{209}$ the Court can issue a warrant for the enforcement of certain orders by a named person, social worker or the police. ${ }^{210}$ The Commission therefore concluded an order for parentage testing should similarly be able to be enforced.

While the Commission did not conclusively state what type of penalty should be imposed it noted that intentional obstruction of an order or execution of a warrant is an offence under the Care of Children Act 2004, with a penalty of imprisonment for a term not exceeding three months or a fine not exceeding $\$ 2500 .{ }^{211}$ For consistency, it concluded that the same penalty should apply in regards to a warrant to enforce a parentage testing order.

Following the Commission's report, a Members' Bill was put forward which proposed that the Family Court should have the ability to order parentage tests, although the Bill was discharged in December 2008. ${ }^{212}$ An almost identical Members' Bill was placed on the list of proposed Members' Bills in February 2012 by National MP Nicky Wagner, ${ }^{213}$ although it has not yet been drawn out of the ballot to be debated before the House. Both Bills proposed that the Family Court should be able to issue a warrant to enforce an order for a parentage test and that intentional obstruction of warrant should carry a penalty of imprisonment for a term not exceeding three months or a fine not exceeding $\$ 2500$.

\footnotetext{
${ }^{208}$ Ibid, at [5.73].

${ }^{209}$ Care of Children Act 2004, s 65.

${ }^{210}$ Sections $72-73$.

${ }^{211}$ Section 79.

${ }^{212}$ Family Proceedings (Paternity Orders and Paternity Tests) Amendment Bill 2008 (202-1).

${ }^{213}$ Family Proceedings (Paternity Orders and Paternity Tests) Amendment Bill 2012.
} 
The recommendations made by the Law Commission and proposed in the two Members' Bills clearly reflect principle G, and balances out the current inconsistency between the ability of children conceived as a result of AHR procedures and naturally conceived children to access information about their genetic origins. Furthermore, if the Family Court can order parentage tests in cases of misattributed paternity, questions concerning biological relationships will be resolved more quickly and most importantly, with absolute certainty.

It is also important to note that in cases of misattributed paternity where the child's non-biological father and/or a biological father have Maori origins, information about the child's genetic origins will be significant in terms of whakapapa and the information can have further legal consequences, for example, in regards to iwi membership. Similarly, it will be important for children with multiple ethnicities to have questions concerning their genetic origins answered as this could affect citizenship rights to other countries.

Finally, it is also of note that parentage testing is not regulated in New Zealand. As pointed out by the Law Commission, there is no accreditation of parentage testing providers in New Zealand and while the results of parentage tests are highly reliable, the testing process is fraught with the potential for error. In addition, samples can be tampered with to skew the results, particularly when the samples are taken privately at home and sent to a parentage testing provider. Therefore the Commission recommended that the Government should develop standards and accreditation of laboratories offering DNA parentage testing in New Zealand, with particular attention to the accuracy of testing and verification of the identity of those providing the samples. ${ }^{214}$ It is very important that the results of parentage tests are accurate. Accuracy would be ensured if this recommendation was implemented.

\section{E Recommendations}

The following amended s 54, new ss 57(3), 57A and 57B reflect recommendation 8 of the Law Commission, and the proposed provisions in the two Member's Bills relating to parentage testing. For clarity, the amendments to the existing provision are in italics.

\footnotetext{
${ }^{214}$ Law Commission New Issues in Legal Parenthood (NZLC R88, 2005) at [5.25].
} 
Recommendation 1: Amend s 54 of the Family Proceedings Act 1980.

\section{Parentage tests}

(1) In any civil proceedings (whether under this Act or not) in which the parentage of a child is in issue-

(a) the court may, of its own motion or on the application of a party to the proceedings, order $^{215}$ that parentage tests be carried out on-

(i) the child; and

(ii) any person who may be a natural parent of the childand that a report of the results be compiled, by a person who is qualified to compile such a report, and submitted to the court;

(b) whether or not the court has made an order under paragraph (a), the court may, of its own motion or on the application of a party to the proceedings, adjourn the proceedings in order to allow time for such parentage tests to be carried out and for such a report to be compiled and submitted to the court.

(2) For the purposes of this section-

(a) parentage tests may be carried out by any person or persons who are qualified to do so, whether or not any of them is the person by whom the report is compiled; and

(b) the consent of a minor who has attained the age of 16 years to submit to parentage tests shall have the same effect as the consent of a person of full age.

Recommendation 2: Insert new subsection 3 into section 57 of the Family Proceedings Act 1980.

\section{Refusal of parentage tests}

(1) In any civil proceedings in which the natural parentage of a child is in issue, whether or not the court has ordered under section 54(1) that parentage tests should be carried out on a person, evidence may be given to the court as to the refusal of that person to consent (or, where the person is under 16 years of age, as to the refusal to consent to such parentage tests of the person who is competent to do so on that person's behalf).

(2) Subject to the right of the person who refuses to consent to the parentage tests to explain the reasons for that person's refusal, and to cross-examine

\footnotetext{
${ }^{215}$ As the Family Court's power to order a parentage test is discretionary, the Court can continue to draw on the principles already developed in case law in deciding whether to recommend a parentage test, which include the welfare and best interests of the child.
} 
witnesses and call evidence, the court may draw such inferences (if any) from the fact of refusal as appear to it to be proper in the circumstances

The Court may ${ }^{216}$ issue a warrant authorising a member of the police or a Social Worker or any other person named in the warrant to take the child (using reasonable force if necessary) and to deliver the child for parentage tests to any person referred to in section 54(2)(a) of this Act."

Recommendation 3: Insert new s 57A into the Family Proceedings Act 1980.

\section{A Execution of warrants ${ }^{217}$}

(1) For the purpose of executing a warrant issued under section 57, a member of the Police or a social worker, or any other person named in the warrant may enter and search any building, aircraft, ship, vehicle, premises, or place, with or without assistance, and by force if necessary.

(2) The member of the Police, social worker, or other person executing the warrant under section 57

(a) must have that warrant with him or her; and

(b) must produce it on initial entry and, if requested, at any later time; and

(c) must identify himself or herself to any person in or on the building, aircraft, ship, vehicle, premises, or place who questions his or her right to enter and search the same or to take possession of the child; and

(d) if he or she is a member of the Police who is not in uniform, must produce evidence that he or she is a member of the Police; and

(e) if he or she is a social worker, must produce evidence that he or she is a social worker; and

(f) if he or she is a person (not being a member of the Police or a social worker) authorised by the warrant to take possession of the child, must produce evidence that he or she is the person so authorised.

Recommendation 4: Insert new s 57B into the Family Proceedings Act 1980.

\section{B Resisting execution of warrant}

(1) Every person commits an offence and is liable on summary conviction to imprisonment for a term not exceeding 3 months, or a fine not exceeding $\$ 2,500$ who-

\footnotetext{
${ }^{216}$ Again this power is discretionary so the Family Court can consider whether it would be in the welfare and best interests of the child to issue a warrant.

${ }^{217}$ This section mirrors s 75 of the Care of Children Act 2004 on the execution of warrants.
} 
(a) knowingly resists or obstructs any person executing a warrant under section 57(3); or

(b) knowingly fails or refuses to afford immediate entrance to all or a part of any premises to any person executing a warrant under section 57(3).

Recommendation 5: The Government should develop standards and accreditation of laboratories offering DNA parentage testing in New Zealand, with particular attention to the accuracy of testing and verification of the identity of samples and persons.

This recommendation mirrors recommendation 4 of the Law Commission.

Recommendation 6: Insert new subsection 10(3A) into the Status of Children Act 1969 to allow for an eligible person to apply directly for a declaration of nonpaternity. This would allow a non-biological father to apply directly.

(3A) A Family Court or the High Court may make a declaration of non-paternity (whether the alleged father or the alleged child or both of them are living or dead) if-

(a) an eligible person applies to the court for the declaration; and

(b) it is proved to the court's satisfaction that the relationship does not exist

Recommendation 7: Amend s 47 and delete s 51 of the Family Proceedings Act 1980.

Section 47 is an amalgamated version of ss 47 and 51. It provides the same test for determining paternity or non-paternity as provided in s 10 of the Status of Children Act 1969 and the same definition of an eligible person. However it retains the provisions regarding the effect of paternity order and the provision that provides who a paternity order can be made against. The Family Court's power is discretionary as it is for the High Court when making declarations of paternity and non-paternity.

It is of note that amendments to the provisions were suggested in the Family Proceedings (Paternity Orders and Paternity Tests) Amendment Bill 2008 and are currently proposed in the Family Proceedings (Paternity orders and paternity tests) Amendment Bill 2012. However this dissertation does not adopt the wording of the Bills, instead opting for wording consistent with s 10 of the Status of Children Act 1969. 


\section{Paternity orders}

(1) In this section, eligible person means a person-

(a) who is a woman and who alleges that a named person is the father of her child; or

(b) who alleges that the relationship of father and child exists between the person and another named person; or

(c) who wishes to have it determined whether the relationship of father and child exists between 2 named persons, and has a proper interest in the result

(2) The Family Court may make a paternity order if-

(a) an eligible person applies to the court for the declaration; and

(b) it is proved to the court's satisfaction that the relationship exists

(3) The Family Court may make an order of non-paternity if-

(a) an eligible person applies to the court for the declaration; and

(b) it is proved to the court's satisfaction that the relationship exists

(4) An application for a paternity order in respect of a child may be made only against a male who-

(a) is not married to, or in a civil union with, the mother; and

(b) has never been married to, or in a civil union with, the mother or (if he

has been married to, or in a civil union with, the mother) whose marriage or civil union was dissolved before the conception of the child

(5) For the purposes of proceedings under section 74, a paternity order in respect of a child shall be conclusive evidence that the person against whom it is made is the father of the child.

Recommendation 8: The Family Court and High Court should have the same discretionary jurisdiction when granting declarations of paternity or non-paternity and the Family Court should have discretionary jurisdiction when granting paternity orders or orders of non-paternity.

This removes the current inconsistency and provides both courts with the same discretionary jurisdiction. It would require s 10(5) of the Status of Children Act 1969 to be amended in some manner. 


\section{Misattributed paternity tort claims}

\section{A Introduction}

As demonstrated in the previous chapter, Family Court proceedings concerning misattributed paternity can have a range of legal outcomes for all the parties involved. Depending on the outcome and potentially the level of animosity between the child's mother and non-biological father, separate tort proceedings may be brought by the child's non-biological father against the child's mother.

In this chapter, the elements of deceit and negligent misstatement are analysed, using various fact patterns to determine whether a successful claim could be brought in New Zealand. The application of the torts to cases of misattributed paternity in England, Australia and Canada is then discussed to determine which approach may be adopted in New Zealand and ultimately whether such a claim may be barred on public policy grounds. Finally, the possibility of tort claims regarding non-consensual and deceitful natural paternity is briefly discussed.

\section{B Deceit and negligent misstatement}

The tort of deceit emerged in the context of commercial transactions in the late $1700 \mathrm{~s}^{218}$ While the tort is still predominantly used to claim damages for deceitful conduct in a commercial context, it has also been successfully pleaded in an employment context, and has slowly begun to emerge in a domestic context. The tort provides a legal remedy for harm suffered as a consequence of fraud, although as Viscount Haldane emphasised in Nocton v Lord Ashburton, ${ }^{219}$ the concept of fraud is wider in some legal contexts than in others. The leading New Zealand case, Amaltal Corporation Ltd v Mahura Corporation, ${ }^{220}$ confirmed that the tort of deceit requires:

(a) proof of a false representation as to a past or existing fact made by a defendant;

(b) who knew it to be untrue or who had no belief in its truth or who was reckless as to its truth;

(c) intention that the plaintiff would act in reliance on the representation;

(d) action by the plaintiff in reliance on the representation; and

(e) proof the plaintiff has suffered damage as a result of relying on the representation.

\footnotetext{
${ }^{218}$ The development of the tort of deceit dates from the famous case of Pasley $v$ Freeman (1789) 3 TR 51; 100 ER 450.

${ }^{219}$ Nocton v Lord Ashburton [1914] AC 932.

${ }^{220}$ Amaltal Corporation Ltd v Mahura Corporation [2007] 1 NZLR 608.
} 
Liability for negligent misstatements was extended by the groundbreaking decision of Hedley Byrne ${ }^{221}$ in which the House of Lords held that a duty of care could lie in making a statement or giving advice to another person. Like deceit, negligent misstatement has predominantly been pleaded in the context of commercial disputes although it has also emerged in a domestic context. Under the principle laid down in Hedley Byrne, as explained and applied in Caparo Industries Plc v Dickman, ${ }^{222}$ there are what could be described as four elements that need to be proven:

(a) the maker of a statement owes a duty of care to persons who they are closely and proximately connected with;

(b) who are intended to rely on the statement for a particular purpose;

(c) who do rely on it for a particular purpose; and

(d) who suffer loss as a consequence of their reliance.

While the torts of deceit and negligent misstatement have been pleaded in the context of misattributed paternity in both common law and civil jurisdictions, this dissertation concentrates on decisions from common law jurisdictions, namely England, Canada and Australia, as New Zealand courts are likely to look to developments in these countries for guidance. As a general overview, in England deceit claims for misattributed paternity can be brought between a former 'cohabitating couple'. ${ }^{223}$ In Australia, deceit claims between former spouses are barred on public policy grounds, but could potentially be brought between parties who had a fleeting sexual relationship. ${ }^{224}$ Negligent misstatement claims can be brought in Australia between 'sexual partners ${ }^{225}$ and in Canada, deceit and negligent misstatement claims between spouses were initially barred, ${ }^{226}$ but now appear to be allowed. ${ }^{227}$ Overall, legal precedent is inconsistent so it is difficult to predict what stance will be adopted in New Zealand.

\footnotetext{
${ }^{221}$ Hedley Byrne \& Co Ltd v Heller \& Partners Ltd [1964] AC 465 (HL).

${ }^{222}$ Caparo Industries Plc v Dickman [1990] 2 AC 605.

${ }^{223}$ P v B (Paternity: Damages for Deceit) [2001] 1 FLR 1041; A v B (Damages for Paternity) [2007] 2 FLR 1051. At the time of printing there were media reports of another successful deceit claim brought by a man against his ex-wife in regards to two children born during the course of their marriage. He was awarded $£ 25,000$ in damages although as a copy of the judgment is not yet available, analysis of the judgment is not included in this dissertation. For further details see Nick Craven "Husband tricked into believing wife's children were his own awarded 25K - for 'bereavement"” (12 January 2013). <www.dailymail.co.uk>

${ }^{224}$ Magill v Magill (2006) 226 CLR 551.

${ }^{225}$ MacDonald v Gray (2005) 41 SR (WA) 22 (Australia). The Judge made a finding of negligent misstatement instead of deceit because of the defendant's honest belief that the plaintiff was the biological father.

${ }^{226}$ Saul v Himel 1994 CarswellOnt 480 (Ont. Gen. Div.); D. (D.R.) v G. (S.E.) 2001 CarswellOnt 299 (Ont. S.C.J.); Rees v Proulx 2001 CarswellOnt 4637 (Ont. S.C.J.).

${ }^{227}$ Thompson $v$ Thompson [2003] A.J. No. 1577 (Alta. Q.B.)
} 


\section{Proving the elements of deceit}

In the following section each of the five elements of deceit defined in Amaltal Corporation Ltd $v$ Mahura Corporation, ${ }^{228}$ are analysed. Five judgments are drawn upon. In $A \vee B^{229}$ the Court concluded all the elements of deceit were made out and accordingly provided analysis of each element. In Magill $v$ Magill the County Court ${ }^{230}$ and the Court of Appeal ${ }^{231}$ discussed all the elements of deceit although the High Court $^{232}$ did not, as the sole issue on appeal was whether such claims should be barred on public policy grounds. ${ }^{233}$ However, Gummon, Kirby and Crennan JJ (in a joint judgment) discussed whether silence amounts to a false representation in the context of marriage and the need for reliance on the representation. Finally, in MacDonald $v$ Gray, ${ }^{234}$ the Judge considered both deceit and negligent misstatement, providing specific guidance on some elements of deceit but not others, as the deceit claim ultimately failed. Overall, the cases provide a patchwork of guidance on the various elements. $^{235}$

\section{False representation}

Firstly, the plaintiff must prove that the defendant made a false representation, namely a false representation that the plaintiff was the biological father of the relevant child. ${ }^{236}$ The falsity of the representation is easily proven by a parentage test but the representation itself may take several forms and be difficult to prove. The most clear cut example of a false representation would be if the defendant said to the plaintiff "you are the father" or words of similar effect. Upon being informed by the defendant of her pregnancy, the plaintiff in $A v B$ asked the defendant whether he was the father of the child, to which she replied that he was. When the plaintiff became suspicious of the child's true paternity several years later due to the child's physical appearance, he put the question to her a second time and she replied that she had "not been with

\footnotetext{
${ }^{228}$ Amaltal Corporation Ltd v Mahura Corporation [2007] 1 NZLR 608.

${ }^{229}$ A v B (Damages for Paternity) [2007] 2 FLR 1051.

${ }^{230}$ Magill v Magill (Unreported, Victoria County Court, Hanlon J, 22 November 2002).

${ }^{231}$ Magill v Magill [2005] VSCA 51.

${ }^{232}$ Magill v Magill (2006) 226 CLR 551.

${ }^{233}$ To avoid confusion between appeals all references to the plaintiff refer to Mr Magill and all references to the defendant refer to Mrs Magill. In addition, all references to the reasoning of the County Court judgment (which was unreported) are made via the Court of Appeal judgment which considered the County Court's reasoning. Finally, for ease of reference each judgment will simply be referred to as Magill.

${ }^{234}$ MacDonald v Gray (2005) 41 SR (WA) 22 (Australia).

235 The Canadian judgments are not discussed further in this section as the main issue in these judgments was whether deceit and negligent misstatement claims should be barred on public policy grounds.

${ }^{236}$ The plaintiff may plead multiple representations see $P$ v B (Paternity: Damages for Deceit) [2001] 1 FLR 1041 in which the plaintiff pleaded 130 separate representations.
} 
anyone else." Accordingly, the Court had no hesitation in finding that the defendant had made a clear unequivocal false representation on both occasions.

However, often such a specific express representation may not have been made. Instead the defendant may have implied through words and conduct that the plaintiff was the child's biological father by requesting or simply allowing him to sign the child's birth registration forms, and stipulating that the child take his surname or a hyphenated surname containing the surnames of both parties. In $A v B$ the Court held that, in addition to the statements made by the defendant, the completion of the child's birth registration form by the defendant naming the plaintiff as the child's father was a false representation. Similarly, in the first instance the County Court Judge in Magill concluded that the "most direct evidence" of a representation was the defendant's completion and presentation to the plaintiff of a birth registration form in which she had named him as the father of the child. ${ }^{237}$ On appeal, the Court of Appeal agreed with this finding although the High Court held that for public policy reasons, false representations could not be made within a marriage in this context.

Usually the main 'representation' is silence as to the child's true paternity. In the first instance the plaintiff in Magill pleaded a number of representations that involved silence, namely: the defendant's concealment of her adultery; the concealment of her uncertainty and suspicions as to paternity; her silence when the plaintiff acted as a father to the children; and the continued concealment of her increasing doubts about paternity. However, the County Court Judge did not determine whether these amounted to false representations as the birth registration forms were the only representations that the Judge tested against the elements of deceit, as he considered them to be the most direct evidence of a representation. ${ }^{238}$ On appeal, the High Court provided some guidance on the issue, noting that in general terms silence will only constitute a misrepresentation if there is a legal or equitable duty to disclose something. Therefore, as there is no duty to disclose an extra-marital affair, the defendant's silence was not a representation. In contrast, Wisbey CDJ in MacDonald $v$ Gray held that as the plaintiff's 'sexual partner', the defendant had a duty not to advise the plaintiff he was the father of the child if the position could be otherwise. ${ }^{239}$

2 That the defendant knows is untrue, is reckless as to its truth or has no genuine belief in its truth

When determining the state of mind of the defendant at the time the false representation was made, a New Zealand court could look at the circumstances

\footnotetext{
${ }^{237}$ This occurred twice in regards to two different children.

${ }^{238}$ Magill v Magill [2005] VSCA 51 at [3].

${ }^{239}$ MacDonald v Gray (2005) 41 SR (WA) 22 (Australia) at [74].
} 
surrounding the conception of the child. Evidence of the frequency of sexual intercourse between the defendant and the plaintiff (and biological father), the estimated date of conception, the use of or failure to use contraception, and any pregnancy tests taken around the time of conception could be taken into account.

In Magill, the defendant had a long term extra-marital relationship with the same man that commenced soon after the birth of her first child to the plaintiff and continued for several years, during which time she gave birth to two more children. Contraception was not used. The County Court Judge concluded that the evidence clearly indicated that the defendant was having more frequent sexual intercourse with her lover than the plaintiff, and by the birth of her third child the frequency of sexual intercourse between the plaintiff and defendant was minimal if not non-existent. In crossexamination the defendant acknowledged that when she became pregnant with her first child: ${ }^{240}$

It was a stressful situation. As I said, I had an uncertainty but still thought it was going to be my husband's child and the easiest way for me to deal with it was to simply block it out.

As to her state of mind the County Court Judge concluded that the evidence pointed very strongly in favour of the conclusion that when the defendant filled in the birth registration forms she knew the plaintiff was not the father of either of the children, or in the very least was reckless as to the truth of her assertion or had no genuine belief in it. On appeal, the Court of Appeal agreed with County Court Judge, concluding that the defendant's representation that the plaintiff was the father of the children was "at best a half truth." ${ }^{241}$

In assessing the defendant's state of mind at the time she made the representation, a New Zealand court could determine whether there is consistency between the evidence given by the defendant in examination in chief and cross-examination. In addition, the Court could look at evidence given by the defendant in previous proceedings concerning the determination of the child's paternity. In $A v B$ the defendant alleged that although she had a one night stand with another man during her on and off again relationship with the plaintiff, she was certain the plaintiff was the father because he was her main sexual partner during the time of the child's conception. However, the Court noted that the defendant's evidence regarding the alleged one night stand was inconsistent between proceedings and ultimately concluded she was not a credible witness, implying she had perhaps fabricated the one night stand and in fact had another regular sexual partner during the time of the child's conception. The Court stated that even if it had accepted her evidence that she

\footnotetext{
${ }^{240}$ Magill v Magill [2005] VSCA 51 at [59].

${ }^{241}$ Ibid, at [64].
} 
had sexual intercourse with the plaintiff three times during the relevant menstrual cycle and only once with her other sexual partner, she could not be $100 \%$ certain who the father was as she had not used contraception with either partner. ${ }^{242}$

It is important to note the Court must determine the state of mind of the defendant at the time she made the representation. It cannot take into account her state of mind at a later time after the representation was made. In many cases of misattributed paternity the defendant's doubt as to the paternity of the child may increase as time goes on. In Magill the defendant admitted she became more suspicious that one of her children was fathered by the man with whom she was having an affair and not the plaintiff when she compared a photo of the man and the child several years after the child's birth. However, the County Court Judge concluded that her admission was not relevant in regards to determining her state of mind at the time she named the plaintiff on the birth registration forms.

In most circumstances it may be relatively straightforward to determine that the defendant in the very least had no genuine belief in the representation. However, it is possible in some circumstances that this requirement will not be satisfied. Indeed, Wisbey DCJ held in MacDonald v Gray that there was sufficient evidence that the defendant held a genuine belief that the plaintiff was the child's father as she took a pregnancy test shortly after a one-off sexual encounter with the child's actual father which gave a negative result. He commented that his impression of the defendant was that she was naïve with a rather simplistic perceptive capacity, and that although someone of more acute perception or reasoning capacity may not have solely relied on a single pregnancy test and dismissed the possibility that the plaintiff was not the father, he was satisfied that her belief was honestly held. ${ }^{243}$ However, her failure to advise the plaintiff of the possibility that he may not be the child's father as she had another sexual partner around the time of the child's conception still gave rise to liability under the tort of negligent misstatement.

Overall, both the English and Australian judgments demonstrate that determining the state of mind of the defendant is a subjective test, not an objective test.

\section{The defendant intended that the plaintiff would act in reliance on the representation}

This requirement may be straightforward to establish by way of evidence or upon admissions made by the defendant in cross-examination, although linking intention to reliance on a representation may be difficult to establish.

\footnotetext{
${ }^{242} A$ v B (Damages for Paternity) [2007] 2 FLR 1051 at [18].

${ }^{243}$ MacDonald v Gray (2005) 41 SR (WA) 22 (Australia) at [69].
} 
In $A \cup B$ it was clear that the defendant intended that the plaintiff would rely on the representation and accordingly help raise the child as she admitted such when pressed in cross- examination. However in Magill, the defendant claimed that she did not intend the plaintiff to rely on the birth registration forms for any purpose other than signing them and agreeing that the children should be registered with the family name of Magill. When asked of her intention at the time she asked the plaintiff to sign the birth registration forms she stated: "I don't think I really thought too hard about it at all, it was a birth registration." 244 The Court of Appeal concluded that her evidence was "redolent of candor" and accordingly that there was no evidence she intended the plaintiff to rely on the forms other than for a specific administrative purpose. ${ }^{245}$

\section{The claimant does rely on the representation}

This requirement is usually straightforward to establish if there is evidence that the plaintiff changed his behaviour after the representation was made, for example, if he supported the defendant financially throughout her pregnancy or cared for the child physically, financially and emotionally. However, it is crucial that reliance is linked to the specific representation that is pleaded by the plaintiff.

In $A v B$ the Court had no hesitation in finding that the plaintiff relied on the defendant's representation as he paid for the defendant's living expenses during her pregnancy, and once the child was born he physically cared for the child and paid for the costs related to the child's care and upbringing. In addition, after the parties separated he continued to be an active parent and paid child support and maintenance to the defendant. The Judge was satisfied that the plaintiff's behaviour was substantially motivated by the numerous representations and it was highly significant that he made no payment of any sort to the defendant before the first representation was made, and none after he received the results of a parentage test which determined that he was not the child's father.

However, linking reliance to the specific representation pleaded by the plaintiff will not always be straightforward as demonstrated in Magill. In the first instance, the County Court Judge concluded the plaintiff had relied on the birth registration forms as he helped raise the two children and continued to pay child support after he and the defendant separated. In addition, he ceased to make child support payments once he found out that he was not the father of the children. However, on appeal the Court of Appeal held that while the birth registration forms were a representation as to paternity there was no evidence that the plaintiff relied on them for any other purpose

\footnotetext{
${ }^{244}$ Magill v Magill [2005] VSCA 51 at [5].

${ }^{245}$ Ibid, at [6].
} 
than signing them and agreeing that the children be registered with the family name of Magill. ${ }^{246}$ The Court considered it crucial that when the plaintiff was asked in evidence why he believed he was the father of the two children he made no reference to the birth registration forms and gave no evidence that the completion of the forms induced him to do anything. Rather, he stated that he cared for the children and provided financial support because he had no reason to believe that he was not the father of the children. ${ }^{247}$ Therefore the Court held that his reliance was on a general assumption that he was the father of the children which was based the marital context and numerous statements and conduct of the defendant not the birth registration forms. ${ }^{248}$ The High Court agreed with the Court of Appeal's conclusion, with Heydon J specifically commenting: ${ }^{249}$

The request for the husband's signature did not call for him to make a particular decision leading to a significant change of circumstances on his part. It would not have appeared to him to be a representation made in order to obtain some advantage. To him the form must have seemed to be no more than a routine administrative document of the kind which parents have to fill in on many occasions in life.

\section{Damage}

Deceit is not actionable per se as it requires proof of damage, which in the current context may be difficult to prove. Firstly, the plaintiff must show a link of causation between the reliance and the damage suffered. Secondly, the damage must be reasonably foreseeable. Finally, the damage must be quantifiable. In Magill and $A v B$ the respective courts highlighted the inherent difficulty in quantifying damages in this context. For example, in Magill the Court of Appeal commented that: ${ }^{250}$

The present case falls not within a category of cases involving guesswork, but as one permitting rational assessment, albeit with some uncertainty.

As a general overview $£ 22,400$ was awarded in $A v B, \$ 8,000$ AUD in MacDonald $v$ Gray and \$70,000AUD in Magill, although this award was overturned on appeal.

\section{(i) Financial damage}

Several types of financial damage have been awarded, for example, the costs associated with the defendant's pregnancy, ${ }^{251}$ the birth of the child, ${ }^{252}$ and the cost of bringing legal proceedings against the defendant to determine the child's paternity. ${ }^{253}$

\footnotetext{
${ }^{246}$ Ibid, at [2].

${ }^{247}$ Ibid, at [2].

${ }^{248}$ Ibid, at [6].

${ }^{249}$ Magill v Magill (2006) 226 CLR 551, at [169].

${ }^{250}$ Magill v Magill [2005] VSCA 51 at [101].

${ }^{251} A \cup B$ (Damages for Paternity) [2007] 2 FLR 1051 at [61].

${ }^{252}$ MacDonald v Gray (2005) 41 SR (WA) 22 (Australia).

${ }^{253}$ Ibid.
} 
The most contentious type of financial damage is the cost of raising the child, which will also usually be the main cost incurred by the plaintiff. For guidance on whether this type of damage can be claimed, courts have drawn on wrongful birth claims brought by parents who sought to recover the cost of raising an unplanned child who was conceived as the result of a negligent sterilization procedure. In Magill the County Court held that costs associated with raising the children were recoverable, following Cattanach v Melchior, ${ }^{254}$ while in $A v B$, the Court held that the costs associated with raising the child were not recoverable, following McFarlane $v$ Tayside Health Board. ${ }^{255}$

In Magill the County Court Judge awarded the plaintiff $\$ 35,000$ for the economic loss incurred as a result of raising the two children. Of this $\$ 35,000, \$ 10,000$ was attributed to a loss of earnings incurred when the plaintiff took time off work after the birth of the children. The remaining $\$ 25,000$ was awarded for expenses incurred while the paternity of the children was resolved in the Family Court, which took some time. A further \$5,000 was awarded for future economic loss. On Appeal, the Court of Appeal commented that it was open to the Judge to award these sums. The Court also considered whether the costs of raising the children could be offset by the benefits obtained by the plaintiff, namely the affection and companionship from the children, but concluded it was not open for the Court to do so as this approach was not approved by the High Court in Cattanach v Melchior. Finally, it is of note that the County Court Judge expressly stated that he was not, in effect, refunding child support payments which had previously been made, rather the sum awarded was for additional financial support provided to the children. ${ }^{256}$

In contrast to Magill, the Judge in $A v B$ refused to classify the cost of raising the child as damage, following McFarlane v Tayside Health Board. Accordingly, the plaintiff's attempt to recover the cost of nappies, formula, nursery furniture, pushchairs as well as nursery and school fees was unsuccessful. ${ }^{257}$ The Judge endorsed the approach taken in McFarlane $v$ Tayside Health Board that: ${ }^{258}$

The law must take the birth of a normal, healthy baby to be a blessing, not a detriment. It brings joy and sorrow, blessing and responsibility. The advantages and disadvantages are inseparable.

\footnotetext{
${ }^{254}$ Cattanach v Melchior (2003) 215 CLR 1 (HCA).

${ }^{255}$ McFarlane v Tayside Health Board [2000] 2 AC 59.

${ }^{256}$ Magill v Magill [2005] VSCA 51 at [100]-[101].

${ }^{257}$ A v B (Damages for Paternity) [2007] 2 FLR 1051 at [61].

${ }^{258}$ McFarlane v Tayside Health Board [2000] 2 AC 59 at [113].
} 
He also noted that in $P \vee B,^{259}$ in which the application of deceit to cases of misattributed paternity was decided as a preliminary issue, the Judge expressed reluctance to regard a human relationship as a loss. ${ }^{260}$ On that basis he refused to award damages to refund the numerous cheques the plaintiff had given the defendant throughout the child's life to cover the cost of raising the child. ${ }^{261}$ However, he did award the plaintiff half the cost of holidays and restaurant meals involving the child, totaling $£ 14,900$, classifying these as 'luxury items' in the sense that they were not necessary for the furtherance of the relationship between the plaintiff and the child.

As courts in England and Australia have opposite views on whether the cost of raising a child is considered damage it is difficult to predict the view a New Zealand court would adopt. The Supreme Court recently confirmed that a pregnancy is a treatment injury when it results from a failed sterilization procedure, and therefore attracts cover under ACC. ${ }^{262}$ This conclusion may influence a New Zealand court to award damages for the cost of raising child. However, it is clear that child support payments would not be regarded as damage in New Zealand as there is provision for the refund of child support payments in the Child Support Act $1991 .^{263}$

(ii) Psychological damages

The plaintiff may suffer distress, anxiety or depression as a result of learning they are not the biological father of the child or children they had raised.

In Magill, the County Court concluded that as a result of the defendant's representation the plaintiff had suffered severe anxiety and depression and accordingly awarded him \$30,000AUD. While the Court of Appeal agreed that the sum awarded by the County Court was appropriate, it disagreed that the plaintiff could prove a causal link between his psychiatric condition and the representation made. Therefore it overturned the award. In the High Court, Gummon, Kirby, Crennan JJ (in a joint judgment) agreed with the Court of Appeal and further commented that: ${ }^{264}$

In an action such as this it will always be difficult to establish whether the pain and suffering alleged by the husband is truly caused by a false representation or is a compound reaction to the distress occasioned by the discovery of what is felt as betrayal and the breakdown of the marriage that it has occasioned. Acknowledging

\footnotetext{
${ }^{259}$ P v B (Damages for Deceit) [2001] 1 FLR 1041.

${ }^{260}$ Ibid, at [40].

${ }^{261} A v B$ (Damages for Paternity) [2007] 2 FLR 1051 at [60].

${ }^{262}$ Allenby $v H$ and Others [2012] NZSC 33.

${ }^{263}$ Child Support Act 1991, s 207.

${ }^{264}$ Magill v Magill (2006) 226 CLR 551 at [134].
} 
this is to recognise the inherent difficulty of establishing reliance (and causation) in such cases.

In $A \vee B$ the Court compared the plaintiff's mental state to the plaintiff in Magill, concluding that while he was devastated by the disclosure as he felt a deep sense of loss and suffered great unhappiness, his mental state had not required medical attention so it was not as severe a case as Magill. On that basis, the Judge made a smaller award of $£ 7,500$. In quantifying the sum the Judge drew guidance from the current payment for bereavement under the Fatal Accidents Act 1976 which is $£ 10,000$.

In MacDonald Wisbey DCJ considered that the plaintiff had suffered minimal or perhaps no emotional distress as he discovered that he was not the father of the child very early on in the child's life. In addition, he only had limited contact with the child so he had not formed a significant emotional bond.

A New Zealand court could draw guidance from nervous shock cases, which require proof of a diagnosable mental injury. Guidance could also be drawn from ACC claims for mental injuries. Because both nervous shock claims and claims under ACC require a diagnosable mental injury, it is doubtful that a plaintiff would be awarded damages for mere distress.

\section{(iii)Vindicatory damages}

A nominal sum could be awarded to mark the wrong suffered by the plaintiff or to recognize the plaintiff's loss of dignity or autonomy. ${ }^{265}$ This would reflect the approach taken in the wrongful birth case of Rees $v$ Darlington Memorial Hospital ${ }^{266}$ in which $£ 15,000$ was awarded to recognise that the plaintiffs had lost the ability to limit the size of their family and to recognise the wrong done by the hospital. While the award of vindicatory damages was not discussed in $A v B$, Magill or McDonald they could be awarded by a New Zealand court as an alternative to awarding damages for the cost of raising the child.

(iv) Exemplary or punitive damages

This type of damage is not intended to compensate a plaintiff but to punish and deter a defendant guilty of outrageous or contumelious conduct. ${ }^{267}$ Exemplary damages were not awarded in $A v B$, Magill or McDonald but could possibly be claimed depending

\footnotetext{
${ }^{265}$ The loss of autonomy is the loss of choice as to whether to raise a non-biological child or not. This choice has been taken away where a man is unaware that he is not the child's biological father.

${ }^{266}$ Rees v Darlington Memorial Hospital NHS Trust [2004] 1 AC 309 (HL).

${ }^{267}$ See generally Taylor v Beere [1982] 1 NZLR 81 (CA).
} 
on the particular facts of the case and the extent of the defendant's deceit and her efforts to conceal it.

\section{Contributory negligence}

As noted in Amaltal Corporation Ltd v Mahura Corporation, ${ }^{268}$ the House of Lords has confirmed that contributory negligence no longer applies in the context of deceit. Therefore, in New Zealand a defendant would be unable to successfully plead contributory negligence if they believed, for example, that the plaintiff suspected that they had another sexual partner at the time of the child's conception. ${ }^{269}$

\section{Time Limitations}

Finally, deceit claims brought in New Zealand courts are subject to the Limitation Act 2010 , although exceptions can be made to the limitation period in cases of fraud. ${ }^{270}$

\section{$D$ Proving the elements of negligent misstatement}

As demonstrated, it may be difficult to prove all the elements of deceit. This section briefly considers whether negligent misstatement may be an alternative remedy, drawing on the case of MacDonald $v$ Gray in which Wisbey CDJ concluded that the defendant was liable in negligent misstatement as opposed to deceit. Comments made by the High Court in Magill in regards to whether a duty of care is owed between spouses are also considered. Finally, the defence of volenti non fit injura is briefly discussed.

1 The maker of a statement concerning the paternity of a child owes a duty of care to persons who they are closely and proximately connected with

In MacDonald, Wisbey DCJ concluded that the defendant was closely and proximately connected with the plaintiff because she was his sexual partner, concluding: ${ }^{271}$

Because of the special relationship that existed between the parties as sexual partners, there was a duty of care on the defendant not to advise the plaintiff that he was responsible for her pregnancy if the position could be otherwise. A false assertion, particularly if maintained over a period of time, had the capacity to result in foreseeable damage.

In contrast, in Magill the High Court held by majority that the defendant had no duty of care when making statements concerning the paternity of the child to the plaintiff in the context of marriage, as such a duty would inherently impose a duty to disclose

\footnotetext{
${ }^{268}$ Amaltal Corporation Ltd v Mahura Corporation [2007] 1 NZLR 608.

${ }^{269}$ Standard Chartered Bank v Pakistan National Shipping Corp [2003] 1 AC 959.

${ }^{270}$ Limitation Act 2010, s 48(1).

${ }^{271}$ MacDonald v Gray (2005) 41 SR (WA) 22 (Australia) at [74].
} 
an extra-marital affair. Because the Court concluded there was no legal basis for a duty to disclose an extra-marital affair there could be no general duty of care in regards to making statements about paternity between spouses. ${ }^{272}$

2 The maker of the statement intends the person to rely on the statement for a particular purpose

See the previous discussion on intention in regards to deceit in section C3. Unfortunately, the defendant's intention is not specifically identified in MacDonald.

\section{The person does rely on the statement for a particular purpose}

See the previous discussion on reliance in regards to deceit in section C4. Again, reliance is not specifically identified in MacDonald.

\section{The person suffers loss as a consequence of their reliance}

See the previous discussion on damage in regards to deceit in section C5. This section includes discussion of the damages awarded in MacDonald.

\section{Volenti non fit injuria}

A person who has voluntarily assumed the risk of harm occasioned by a breach of a duty by the defendant is barred from making a successful claim as the maxim "volenti non fit injura" applies. ${ }^{273}$ In order for a person to be held to have assumed the risk it must be shown that the person had full knowledge of the risk and freely and voluntarily accepted it. ${ }^{274}$ The onus is on the defendant to prove that the plaintiff assumed the risk of that harm. ${ }^{275}$ As these are stringent conditions, the defence rarely succeeds. $^{276}$

In cases of misattributed paternity the defendant would have to prove that the plaintiff knew they were not the defendant's only sexual partner and perhaps also that the defendant was not using contraception with the other sexual partner. This would be a very difficult requirement to satisfy as in most cases where the parties are in a relationship the plaintiff will have been completely unaware that he is not the defendant's only sexual partner. Even if he was aware of this fact it would be rare for him to fully accept the risk, instead it is likely that he will attempt to clarify the paternity of the child with the defendant.

\footnotetext{
${ }^{272}$ Magill v Magill (2006) 226 CLR 551 at [129]-[130].

${ }^{273}$ The maxim means "no harm is done to one who consents".

${ }^{274}$ Osborne v London and North Western Railway (1888) 21 QBD 220, 223-224 per Wills J.

${ }^{275}$ James v Wellington City [1972] NZLR 978 (CA); Morris v Murray [1991] 2 QB 6 (CA).

${ }^{276}$ Stephen Todd The Law of Torts in New Zealand (5 ${ }^{\text {th }}$ ed, Brookers, Wellington, 2009) at [21.4.01].
} 


\section{Contributory negligence}

This could be pleaded by the defendant although as with the defence of volenti non fit injura, it may be difficult to prove because in most cases the plaintiff will have been unaware that he was not the defendant's only sexual partner. Accordingly, in MacDonald the defence was rejected. ${ }^{277}$

\section{Time limitations}

See the previous discussion on time limitations in regards to deceit in section C7.

\section{E Conclusions on proving the elements of deceit and negligent misstatement}

If a deceit or negligent misstatement claim were to come before a New Zealand court there is a range of guidance that could be drawn on from $A v B$, the three Magill judgments and MacDonald to determine whether each of the elements have been proven on the facts. In regards to a claim for deceit, the greatest difficulty a plaintiff may face is proving a chain of causation between the specific representation, reliance and loss as a result of the reliance. The type of damages that are appropriate to award could also be a major issue.

In regards to a claim for negligent misstatement, it may be difficult for a married plaintiff to argue that they were owed a duty of care by the defendant when making statements concerning paternity as this could be seen as creating a corresponding duty to disclose an extra-marital affair. However, if the parties were not married and therefore no extra-marital affair occurred, it may be easier to argue a duty of care was owed. While the outcome of a New Zealand claim will ultimately depend on the particular facts, it is possible that all the elements of deceit or negligent misstatement could be proven.

\section{F Application of deceit and negligent misstatement to misattributed paternity}

In determining whether a claim should succeed, some courts have simply determined whether all the elements of the tort have been proven in order to determine liability without considering whether the application of the tort is appropriate. However, other courts have considered whether, as a matter of law, deceit or negligent misstatement claims can be brought in the context of misattributed paternity or whether there are public policy reasons that justify a bar on such claims. In this section the various approaches are considered and comments are then made on the approach a New Zealand court may adopt.

\footnotetext{
${ }^{277}$ MacDonald v Gray (2005) 41 SR (WA) 22 (Australia) at [76].
} 


\section{England}

P v B (Paternity: Damages for Deceit) ${ }^{278}$ was the first deceit claim for misattributed paternity to come before a court in England. In deciding the preliminary question of whether the tort of deceit can be applied in a domestic context as opposed to a commercial context, the judge held that there was no authority which denied the application of the tort and held that is has a general and flexible application. ${ }^{279} \mathrm{He}$ considered that because torts of negligence and trespass to the person applied in a domestic context it would be anomalous to except deceit and rejected an argument that such claims interfere with private domestic relationships, commenting: ${ }^{280}$

I do not think that liability for deceit is an undesirable interference by the law in the domestic relations of a man and a woman. Actions for deceit between couples will in practice be commenced only when their relationship has broken down. An action in deceit will not cause the breakdown of the relationship: more likely, the breakdown in the relationship will be the consequence of the fraud.

Overall, he considered that the law should encourage honesty between couples, rather than condone dishonesty and that to accede to arguments for confining the tort would be to deny a remedy in cases where it was needed. ${ }^{281}$ On that basis, he concluded that deceit claims for misattributed paternity could be brought in a between former "cohabitating couples.",282

However, he recognised that there should be several limitations to the application of deceit in the context of misattributed paternity, for example, he recognised that it would be inappropriate to award damages if to do so conflicted with orders concerning child support payments made in the Family Division of the High Court. ${ }^{283}$ Essentially, it would be an abuse of process to attempt to re-litigate the question by means of an action for deceit.

The reasoning in $P v B$ (Paternity: Damages for Deceit) was subsequently followed in $A \vee B$. The Judge also rejected a "floodgates argument" that if the action was allowed to proceed and was successful, it would be followed by a flood of other similar cases. The Judge commented that: ${ }^{284}$

If this is a cause of action for which justice requires a remedy, then it is right that a remedy be granted, and I am unmoved by the thought that other similar cases may come forward.

\footnotetext{
${ }^{278}$ P v B (Paternity: Damages for Deceit) [2001] 1 FLR 1041.

${ }^{279}$ No subsequent claim was made to determine whether the elements of the tort had been proven.

${ }^{280}$ P v B (Paternity: Damages for Deceit) [2001] 1 FLR 1041 at [28].

${ }^{281}$ Ibid, at [34].

282 Ibid, at [50].

${ }^{283}$ Ibid, at [33].

${ }^{284}$ A v B (Damages for Paternity) [2007] 2 FLR 1051 at [46].
} 
He also noted that there had only been one other English claim, one Australian claim and a few in the United States so at present "the anxiety of a flood of similar cases seems to be somewhat over-stated.",285

\section{Australia}

In the first instance the County Court Judge in Magill did not consider the applicability of the tort of deceit, instead he simply determined whether all the elements of the tort had been proven on the facts. On appeal to the Court of Appeal Eames $\mathrm{J}$ considered the reasoning in $P v B$ and noted that while it was unnecessary to conclude on the torts application as all the elements had not been proven causing the claim to fail, he could see "no impediment" to its application to representations regarding paternity. He further stated: ${ }^{286}$

Whilst there may be good reason to discourage traumatic litigation such as has arisen in this case, it is not the function of this Court to apply social considerations so as to deny a party a remedy which is otherwise open to him or her. The respondent's motive for bringing this proceeding is irrelevant. A remedy in damages for a wrong done may provide not merely recompense for financial loss, but also, in the eyes of the claimant, an element of punishment for the wrong done, and vindication of the rights of the party wronged. There is, therefore, nothing unique to the tort of deceit if it was being applied by the representee with motives of personal vindication and of punishment of the alleged wrongdoer.

On appeal to the High Court the majority disagreed with Eames J with five of the six judges concluding that the defendant was entitled to immunity from suit. In a joint judgment, Gummon, Kirby and Crennan JJ held that deceit did not apply to false representations made during a marriage about paternity or about an extramarital affair. This was for two reasons. Firstly, there was an existing statutory framework that facilitated the accurate determination of paternity, and the Government had recently passed legislation which provided that the determination of fault between spouses, including inquiry into their extra-marital sexual conduct, is no longer the province of the law. An action for deceit would cut across this comprehensive statutory framework, and accordingly, it was not appropriate for the common law to develop in this way. ${ }^{287}$

Secondly, there was a 'mantle of privacy' which protected sexual conduct within a marriage from the scrutiny by the law. There was no legal or equitable obligation on a person to disclose an extra-marital sexual relationship to their spouse during the course of a marriage, and it was inappropriate to assess the parties conduct by

\footnotetext{
${ }^{285}$ Ibid, at [48].

${ }^{286}$ Magill v Magill [2005] VSCA 51 at [47].

${ }^{287}$ Magill v Magill (2006) 226 CLR 551 at [87].
} 
reference to bargaining transactions, to which the tort of deceit was typically associated. ${ }^{288}$ However, the Court recognised that tort actions can arise between spouses and that a duty of disclosure exists in certain contractual negotiations, and if one spouse has a sexually transmitted disease. It noted these actions are allowed because contractual negotiations can be equated with commercial transactions which are a province of the law, and the transmission of sexually transmitted disease carries the risk of physical harm, therefore both are valid exceptions. ${ }^{289}$

Hayne J agreed with the majority, concluding that there could be no satisfactory application of an objective and generalized standard of conduct to a very particular and personal relationship in which it was the parties themselves who would mold the way in which their relationship was ordered and conducted. ${ }^{290}$ Gleeson J was satisfied that in principle deceit could apply to representations regarding paternity, noting that false representations could be made in a variety of contexts, some of which may be closely linked to property or financial undertakings. He considered that while the application of deceit to marital relations is not impossible, and there are no rigidly defined zones of exclusion, attempts to construct legal rights and obligations in unsuitable environments must fail. ${ }^{291}$

In the only dissenting judgment, Heydon $\mathbf{J}$ agreed with Gleeson $\mathrm{J}$ that in principle an action in deceit could lie in cases of misattributed paternity as tort actions were generally available between spouses. On this basis there was no good reason to create an anomaly for deceit, endorsing the principle from Nocton $v$ Lord Ashburton ${ }^{292}$ that honesty is a duty of universal obligation.

Finally, Wisbey CDJ did not consider the application of deceit or negligent misstatement to paternity representations in MacDonald, instead he solely considered whether the elements of the torts had been proven.

\section{Canada}

Deceit and negligent misstatement were both pleaded in Saul v Himel ${ }^{293}$ although the application of torts was decisively rejected. The Judge held that the plaintiff's action "offended public policy" and that marriage is still a private domain so the public, through the judicial system, should not be involved in scrutinizing the behavior of

\footnotetext{
${ }^{288}$ Ibid, at [88].

${ }^{289}$ Ibid, at [129].

${ }^{290}$ Ibid, at [164].

${ }^{291}$ Ibid, at [49].

${ }^{292}$ Nocton v Lord Ashburton [1914] AC 932 at 954.

${ }^{293}$ Saul v Himel 1994 CarswellOnt 480 (Ont. Gen. Div.).
} 
spouses in private matters. ${ }^{294}$ This conclusion was upheld on appeal ${ }^{295}$ and subsequently followed in D. (D.R.) v G. (S.E. $)^{296}$ and Rees $v$ Proulx. ${ }^{297}$ More recently, the opposite view was taken in Thompson $v$ Thompson ${ }^{298}$ where the Court held, as a preliminary matter, that a claim in deceit could be brought between former spouses because to bar such claims would be tantamount to the Court directing that fraud is condoned in cases of misattributed paternity. ${ }^{299}$

\section{New Zealand}

England and Australia have taken very different approaches to the application of deceit to cases of misattributed paternity. ${ }^{300}$ In England, allowing deceit claims in the context of misattributed paternity is regarded as a natural development of tort law, whereas in Australia, public policy reasons are regarded as significant enough to justify a bar on deceit claims in most circumstances. The position in Canada was similar to that in Australia until recently, although as no guidance can be drawn from Thompson, the Canadian position is not discussed further. On that basis, the main question for consideration is whether a New Zealand Court will adopt the English or Australia approach when a deceit or negligent misstatement claim comes before it.

As there is no general statutory bar in New Zealand on married or unmarried couples suing each other in tort in a domestic context, ${ }^{301}$ public policy reasons are the only barrier to the success of a deceit or negligent misstatement claim where the defendant has successfully proven all the required elements. In the only New Zealand commentary on the application of tort law to cases of misattributed paternity, Todd argues that the two public policy reasons given by the majority in Magill, or very similar reasons, arguably apply with force in New Zealand. Therefore, New Zealand courts are likely to follow the Australian approach. ${ }^{302}$ These two reasons are analysed further in this chapter to determine whether they are robust or require further consideration.

\footnotetext{
${ }^{294}$ Ibid, at [20].

${ }^{295}$ Saul v Himel 1996 CarswellOnt 1369 Ont. S.C.J.).

${ }^{296}$ D. (D.R.) v G. (S.E.) 2001 CarswellOnt 299 (Ont. S.C.J.).

${ }^{297}$ Rees v Proulx 2001 CarswellOnt 4637 (Ont. S.C.J.).

${ }^{298}$ Thompson v Thompson [2003] A.J. No. 1577 (Alta. Q.B.).

${ }^{299}$ Ibid, at [30]. A brief reference to this judgment was made in Raju v Kumar 2006 BCSC 439 although the author has not been able to obtain a copy of the judgment as it was unreported.

${ }^{300}$ Furthermore, the approach adopted in MacDonald $v$ Gray could be regarded as inconsistent with the Magill High Court judgment.

${ }^{301}$ Relationship Property Act 1976, s 51. The section provides that each of the parties to a marriage or civil union shall have the like right of action in tort against the other as if they were not married or in a civil union.

${ }^{302}$ Stephen Todd "Review: Tort" (2007) NZLR 773; Stephen Todd The Law of Torts in New Zealand ( $5^{\text {th }}$ ed, Brookers, Wellington, 2009).
} 
(1) Tort claims for misattributed paternity cut across a 'no fault' statutory framework concerning divorce and the accurate determination of paternity

Todd argues that the New Zealand statutory framework on divorce and paternity is similar to that in Australia as it is non-fault based. More specifically he argues that legislation concerning the dissolution of marriage, ${ }^{303}$ child support, ${ }^{304}$ property, ${ }^{305}$ and care of children ${ }^{306}$ all: ${ }^{307}$

...seek so far as possible to resolve disputes and agreements between the parties without allocating blame and responsibility. The very process of investigation into matters of fault - "digging up the dirt" - is seen as contrary to the welfare and best interests of the child.

Generally speaking the New Zealand statutory framework is non-fault based, although it is questionable that tort claims should be barred on the basis that 'digging up the dirt' is contrary to the welfare and best interests of the child. As discussed in the previous chapter, court proceedings concerning misattributed paternity are inherently about 'digging up the dirt' in order to determine who is the biological father of the child. Such proceedings are not regarded as contrary to the welfare and best interests of the child. This is evident in the fact that courts have ordered children to undergo parentage tests because it considers that it is in the welfare and best interests of the child to know who their biological father is. ${ }^{308}$ It is also significant that there is a statutory provision that allows a non-biological father to apply for a declaration of non-paternity as this further supports the notion that the statutory framework encourages truth about paternity. Furthermore, if there is a dispute about the paternity of a child it is an offence to pretend to be the biological parent of a child and take a parentage test on behalf of someone else, or provide a 'stand in' child in the place of the child who should actually be taking the test. ${ }^{309}$ Therefore family law legislation does allocate blame and responsibility in scenarios involving misattributed paternity where there is a deliberate intent to deceive. For these reasons, tort claims could be regarded as consistent with the existing statutory framework, as opposed to cutting across it.

\footnotetext{
${ }^{303}$ Family Proceedings Act 1980.

${ }^{304}$ Child Support Act 1991.

${ }^{305}$ Property Relationships Act 1976.

${ }^{306}$ Care of Children Act 2004.

307 Stephen Todd "Review: Tort" (2007) NZLR 773; Stephen Todd The Law of Torts in New Zealand ( $5^{\text {th }}$ ed, Brookers, Wellington, 2009).

${ }^{308}$ See $T v S$ [Guardianship] [2005] NZFLR 466 (CA).

${ }^{309}$ Family Proceedings Act 1980, s 59. The offence results in a $\$ 1000$ fine.
} 
Secondly, it could be argued that tort claims do not cut across the existing statutory framework, rather they are entirely separate and exist concurrently alongside it. They are not a 'second bite to the cherry' as the plaintiff is not attempting to re-litigate previous Family Court proceedings concerning the parties' separation and the paternity of the child in order to have the outcome changed. Indeed the success of a tort claim will have no impact on orders previously made by the Family Court. In addition, tort claims have a different purpose to statutory proceedings. The main purpose of statutory proceedings is to resolve the legal status of the parties whereas the sole purpose of tort claims is to award compensation. As there is no statutory mechanism to award compensation for 'damage' caused by misattributed paternity, tort claims to seek compensation therefore arguably do not cut across the existing statutory framework.

However, as Todd explains, there two clear instances when tort claims do cut across the existing statutory framework and should therefore be barred. Firstly, where the plaintiff seeks to have child support payments refunded through an award of damages. This would be a clear abuse of process as the Child Support Act 1991 provides a comprehensive framework for the payment of child support and specifically provides for the refund of child support payments. ${ }^{310}$ Secondly, claims should be barred if the plaintiff seeks to use tort proceedings to delay relationship property proceedings. Section 51(2) of the Property Relationships Act 1976 provides the courts with a discretionary power to stay proceedings between spouses or de facto couples if they are of no substantial benefit to either party, are vexatious, or the question in issue could be more conveniently resolved under the Act. In Ross $v \operatorname{Ross}^{311}$ a husband's defamation action against his wife was barred on the basis that it was in the interests of the parties and the children of the marriage that the financial and parental issues between them be resolved as soon as possible, and not delayed by the tort proceedings directly or indirectly. ${ }^{312}$ Accordingly, if a deceit or negligent misstatement claim is lodged while relationship property proceedings are underway and delays those proceedings, it should be stayed.

(2) There is a 'mantle of privacy' which protects sexual conduct within a marriage (and other long term relationships short of marriage) from scrutiny by the law

While this could be regarded as a valid public policy reason for barring such claims, it also creates numerous anomalies. The High Court of Australia has acknowledged that there is not a mantle of privacy over sexual conduct within a marriage where a person

\footnotetext{
${ }^{310}$ Child Support Act 1991, s 207.

${ }^{311}$ Ross v Ross HC Auckland CP 219-SD000, 27 March 2001.

${ }^{312}$ Ibid, at [16].
} 
fails to disclose that they are HIV positive. ${ }^{313}$ In such circumstances, a spouse is not barred from bringing a battery claim as the Court considered there is a duty to disclose because failure to do so results in harm. Similarly, in cases of misattributed paternity there is also a failure to disclose important information that arguably results in harm. The High Court distinguished cases of potential HIV transmission on the basis that the harm is physical, although as previously discussed, 'harm' in the context of tort claims is not solely limited to physical harm. Indeed, the Australian High Court has previously held that the cost of raising an unplanned child is harm. ${ }^{314}$ The High Court's conclusion that spouses should be able to bring battery claims is also inconsistent with the Court's conclusion that tort claims should not cut across the 'no fault' statutory framework. ${ }^{315}$

Secondly, concluding that there is a mantle of privacy over sexual conduct within a marriage but not over sexual conduct within a long or short-term relationship creates an additional anomaly as it bars certain people from bringing claims and not others. A male who was married to the child's mother for 20 years would be barred from bringing a claim under Magill but a male who had a one off sexual encounter with the child's mother could potentially bring a claim. ${ }^{316}$ This appears illogical as the level of psychological and financial harm suffered is likely to be higher for a male who was married to the child's mother (particularly if married for a long period of time) than a man who had a fleeting sexual relationship with the child's mother. Furthermore, it could be argued that barring claims depending on the relationship status of the parties could amount to prima facie discrimination on the grounds of marital status under the New Zealand Bill of Rights Act 1990. ${ }^{317}$

In conclusion, the public policy grounds for barring claims in Magill should be considered although for the reasons given, a New Zealand Court should not readily adopt these grounds without further consideration of them in a New Zealand context. However, there are two clear instances where a tort claim should be barred in New Zealand. Firstly, where the plaintiff seeks to recover previously made child support payments, and secondly, where the plaintiff has lodged a claim to deliberately delay relationship property proceedings.

\footnotetext{
${ }^{313}$ Magill v Magill (2006) 226 CLR 551.

${ }^{314}$ Cattanach v Melchior (2003) 215 CLR 1 (HCA).

${ }^{315}$ For further commentary on this point see K.R. Handley "Paternity Fraud" (2007) Law Quarterly Review, 123:337.

${ }^{316}$ For further commentary on this point see Henaghan et al Family Law in New Zealand $\left(15^{\text {th }}\right.$ ed, Lexis Nexis, Wellington, 2011) at [6.521].

${ }^{317}$ Human Rights Act 1993, s 21(1)(b).
} 


\section{G Tort claims for non-consensual and deceitful paternity}

While no deceit or negligent misstatement claims in regards to non-consensual or deceitful natural paternity have emerged in the common law jurisdiction, a significant number have been brought in the United States for false representations about contraception $^{318}$ and infertility. ${ }^{319}$ There are also two reported cases in which the plaintiff argued that the defendant 'stole' their sperm in the course of oral sex and subsequently inseminated the sperm without their knowledge to conceive the child. ${ }^{320}$ While some courts have accepted the elements of the torts could be proven, none of the claims made thus far have been successful as all have been barred on public policy grounds.

Tort liability could also arise in the context of non-consensual artificial paternity. If a woman deceived a hospital or medical clinic into allowing her to use a former partner's semen or embryos created using his semen without his consent, the former partner could bring an action in injurious falsehood. Possible conversion or negligence claims could also arise as the Court of Appeal in England recently held that males have property rights in samples of their sperm that are frozen and stored by a third party. ${ }^{321}$ Although less likely, property rights in embryos may also be recognised in future which could result in further claims.

\footnotetext{
${ }^{318}$ See for example Wallis $v$ Smith 2001-NMCA-017, 130 N.M. 214.

${ }^{319}$ See for example Welzenbach $v$ Powers 660 A.2d 1133(N.H. 1995).

${ }^{320}$ Phillips v Irons 354 Ill.App.3d 1164; State v Frisard 694 So.2d 1032 (La.Ct.App.1997).

${ }^{321}$ Yearworth and others $v$ North Bristol NHS Trust [2009] 3 W.L.R. 118.
} 


\section{Conclusion}

This dissertation has proven that non-consensual, deceitful, and misattributed paternity is a modern reality that has serious practical and legal consequences for all parties involved, but particularly for the father and the child. Furthermore, these types of paternity do not sit comfortably within the current legal framework on paternity which is too rigid, unclear, or outdated to resolve the issues that arise, and in some instances, result in inequitable outcomes. Therefore, changes must be made.

Eleven recommendations have been provided throughout this dissertation. They are summarised as follows:

(1) A new provision, s 18A, should be inserted into Part 2 of the Status of Children Act 1969 to determine the legal status of a male whose semen or embryos containing his semen were used in an AHR procedure without his consent.

(2) The Governor-General should pass an order in council in accordance with $\mathrm{s}$ 76(1)(ii) of the Human Assisted Reproductive Technology Act 2004 to provide regulations on the use or destruction of in vitro fertilised embryos in cases where one party from whom such a gamete or embryo has been obtained withdraws consent to any course of action.

(3) Deception used to bring about the conception of a child should be added as a ground for a departure order under s 105 of the Child Support Act 1991.

(4) Section 54 of the Family Proceedings Act 1980 should be amended to allow the Family Court to order parentage testing.

(5) Section 57 of the Family Proceedings Act 1980 should be amended to give the Family Court a discretionary power to issue a warrant authorising certain people to take steps to enforce an order issued under s 54.

(6) Insert new s 57A into the Family Proceedings Act 1980 which provides requirements in regards to the execution of a warrant issued under s 57.

(7) Insert new s 57B into the Family Proceedings Act 1980 which provides that it is an offence to resist or obstruct the execution of a warrant made under s 57.

(8) The Government should develop standards and accreditation of laboratories offering DNA parentage testing in New Zealand, with particular attention to the accuracy of testing and verification of the identity of samples and persons.

(9) Amend s 10 of the Status of Children Act 1969 to allow an eligible person to apply directly for a declaration of non-paternity.

(10) Amend s 47 of the Family Proceedings Act 1980 (and delete s 51) to allow a male to apply for a paternity order and to allow an eligible person (including a male) to apply for a non-paternity order. 
(11) Amend s 10(5) of the Status of Children Act 1969 so that both the High Court and Family Court have the same discretionary jurisdiction to grant declarations of paternity or non-paternity.

It is also concluded that deceit and negligent misstatement claims for misattributed could be successfully pleaded in New Zealand. However, such claims may be barred on the public policy grounds identified in Magill. While public policy grounds for barring claims need to be considered, New Zealand courts should not adopt the approach of the High Court of Australia without carefully considering the Court's reasoning in a New Zealand context. However, as discussed, there are two instances where claims should be barred. Firstly, where the plaintiff seeks to recover child support payments, as the proper course is to use s 207 of the Child Support Act 1991, or where the plaintiff is attempting to delay relationship property proceedings. In these two instances, claims are an inherent abuse of process.

Finally, although this dissertation provides a number of practical recommendations it is not based on the assumption that it provides all the answers to the complex legal issues that arise as a result of non-consensual, deceitful and misattributed paternity. These issues concern complex aspects of human behaviour and are therefore inherently difficult to resolve. In addition, they concern societal values which are constantly changing. Ongoing consideration of these issues is therefore needed. Indeed some of the topics discussed in this dissertation, namely child support, ${ }^{322}$ and the role of the Family Court, ${ }^{323}$ are currently under review. Hopefully, the recommendations stimulate further discussion and research within both the academic and political community in New Zealand and overseas.

\footnotetext{
${ }^{322}$ Child Support Amendment Bill 2011 (337-1).

${ }^{323}$ Ministry of Justice "Family Court Review" < www.justice.govt.nz>
} 


\section{BIBLIOGRAPHY}

\section{PRIMARY SOURCES}

\section{New Zealand legislation}

Administration Act 1969

Adoption Act 1955

Births, Deaths, Marriages, and Relationships Registration Act 1995

Care of Children Act 2004

Child Support Act 1991

Citizenship Act 1977

Contraception, Sterilisation, and Abortion Act 1977

Crimes Act 1961

Family Proceedings Act 1980

Family Protection Act 1955

Guardianship Act 1968

Health and Disability Commissioner (Code of Health and Disability Services Consumer's Rights) Regulations 1996

Human Assisted Reproductive Technology Act 2004

Human Rights Act 1993

Interpretation Act 1999

Limitation Act 2010

New Zealand Bill of Rights act 1990

Status of Children Act 1969

Status of Children Amendment Act 2004

\section{Legislation from England, Australia, Canada and USA}

Assisted Human Reproduction Act 2004

Assisted Reproductive Technology Act 2007

Assisted Reproductive Treatment Act 2008

Fatal Accidents Act 1976

Human Fertilisation and Embryology Act 1990

Human Reproductive Technology Act 1991

Michigan Paternity Act, Mich. Comp. Laws § 722.711 (2002)

Reproductive Technology Act 1988

Safe Delivery of Newborns Act, Mich. Comp. Laws § 712.1-712.20 (2002) 


\section{International conventions}

United Nations Convention on the Rights of the Child

\section{New Zealand cases}

Allenby $v$ H and Others [2012] NZSC 33

Amaltal Corporation Ltd v Mahura Corporation [2007] 1 NZLR 608 (CA)

C v R (2002) 22 FRNZ 408 (HC)

CLM v Accident Compensation Corporation [2006] 3 NZLR 127 (HC)

Cook v Gibbons (1986) 3 FRNZ 257 (HC)

Ewens v Director General of Social Welfare (1992) 9 FRNZ 371 (FAMC)

Fletcher v Blackburn [Guardianship] [2009] NZFLR 354 (HC)

Hall v Vail [1972] NZLR 95

Hemmes $v$ Young [2005] NZSC 47

$K v P$ [2004] 2 NZLR 421 (HC)

$K S B v$ Accident Compensation Corporation [2012] NZCA 82

$L v R$ FC Nelson FAM-2005-042-489, 21 September 2007

$L T G-S v L R P$ [2012] NZFC 463

$M v$ Family Court at Waitakere HC Auckland CIV-2010-404-7814, 16 December 2010.

MLF v HJF FC Tauranga FAM-2005-070-1287, 1 July 2008.

$R v$ Mwai [1995] 3 NZLR 149

Ross v Ross HC Auckland CP 219-SD000, 27 March 2001.

Rowlands (formerly McLean) and Rowlands v McLean (1989) 2 FLB (FAMC)

$T$ v S [Guardianship] [2005] NZFLR 466 (CA)

Tanner v Edghill [2008] NZFLR 262 (HC)

Taylor v Beere [1982] 1 NZLR 81 (CA)

WJCR v Commissioner of Inland Revenue FC North Shore FAM-2009-044-1319, 12

October 2009

\section{Cases from England, Australia, Canada and USA}

$A v B$ (Damages for Paternity) [2007] 2 FLR 1051

$A Z$ v BZ 431 Mass 150 (2000)

$C v S$ [1988] QB 135

Cattanach v Melchior (2003) 215 CLR 1 (HCA)

Clark v Jeter 486 U.S. 456 (1988)

D. (D.R.) v G. (S.E.) 2001 CarswellOnt 299 (Ont. S.C.J.) 
Davis v Davis 842 SW 2d (Tenn 1992)

Dubay $v$ Wells and Attorney General 6 F.3d 422 (6th Cir, 2007)

Evans v Amicus Healthcare Ltd [2003] EWHC 2161 (Fam)

Evans v Amicus Healthcare Ltd [2004] EWCA Civ 727

Evans v United Kingdom [2006] 1 FCR 585 (ECHR)

Hedley Byrne \& Co Ltd v Heller \& Partners Ltd [1964] AC 465 (HL)

In Re R (A Child)(IVF: Paternity of Child) [2005] UKHL 33

James $v$ Wellington City [1972] NZLR 978 (CA)

$J B v M B 783$ A 2d 707 (NJ 2001)

Kass v Kass 91 NY 2d 554 (1998)

Kulko v Superior Court of California 436 U.S. 84, 98 (1978)

Litowitz v Litowitz 10 P 3d 1086 (Wash Ct App 2000)

MacDonald v Gray (2005) 41 SR (WA) 22

Magill v Magill (Unreported, Victoria County Court, Hanlon J, 22 November 2002)

Magill v Magill [2005] VSCA 51

Magill v Magill (2006) 226 CLR 551

McFarlane $v$ Tayside Health Board [2000] 2 AC 59

Morris v Murray [1991] 2 QB 6 (CA)

Nocton v Lord Ashburton [1914] AC 932

Osborne v London and North Western Railway (1888) 21 QBD 220

P v B (Damages for Deceit) [2001] 1 FLR 1041

Pasley v Freeman (1789) 3 TR 51; 100 ER 450

Phillips v Irons 354 Ill.App.3d 1164

Planned Parenthood of Southeastern Pennsylvania v Casey 505 U.S. 833 (1992)

$R$ v Cuerrier [1998] 2 SCR 371

Raju v Kumar 2006 BCSC 439

Rees v Darlington Memorial Hospital NHS Trust [2004] 1 AC 309 (HL)

Rees v Proulx 2001 CarswellOnt 4637 (Ont. S.C.J.)

Roe $v$ Wade 410 U.S. 113 (1973)

Saul v Himel 1994 CarswellOnt 480 (Ont. Gen. Div.)

Saul v Himel 1996 CarswellOnt 1369 (Ont. S.C.J.)

Standard Chartered Bank v Pakistan National Shipping Corp [2003] 1 AC 959

State v Frisard 694 So.2d 1032 (La.Ct.App.1997)

Thompson v Thompson [2003] A.J. No. 1577 (Alta. Q.B.)

Wallis $v$ Smith 2001-NMCA-017, 130 N.M. 214

Welzenbach $v$ Powers 660 A.2d 1133(N.H. 1995)

Yearworth and others $v$ North Bristol NHS Trust [2009] 3 W.L.R. 118 


\section{New Zealand Hansard}

(24 November 2005) 628 NZPD 503

\section{New Zealand Bills}

Family Proceedings (Paternity Orders and Paternity Tests) Amendment Bill 2008 (202-1)

Family Proceedings (Paternity Orders and Paternity Tests) Amendment Bill 2012 Child Support Amendment Bill 2011 (337-1)

\section{SECONDARY SOURCES}

\section{New Zealand Reports}

Law Commission New Issues in Legal Parenthood (NZLC R88, 2005)

National Population Estimates: March 2012 quarter (Statistics New Zealand, March 2012)

Supporting children: A Government discussion document on updating the child support scheme (Inland Revenue, September 2010)

\section{Journal articles}

Frances Goldscheider "Men, Children and the Future of the Family in the third Millennium" (2000) 32 Futures, 527-538

K.R. Handley "Paternity Fraud" (2007) Law Quarterly Review, 123:337

Stephen Todd "Review: Tort" (2007) NZLR 773

\section{Texts}

Bruce Robertson (ed) Adams on Criminal Law (2011 student ed, Brookers)

Craig Lind, Heather Keating Jo Bridgeman (eds) Taking responsibility, law and the changing family (Ashgate Publishing, Burlington, 2011)

Henaghan and Atkin Family Law Policy in New Zealand $\left(4^{\text {th }}\right.$ ed, Lexis Nexis, Wellington, 2013)

Henaghan et al Family Law in New Zealand (1 $1^{\text {th }}$ ed, Lexis Nexis, Wellington, 2003) Henaghan et al Family Law in New Zealand $\left(13^{\text {th }}\right.$ ed, Lexis Nexis, Wellington, 2007) Henaghan et al Family Law in New Zealand $\left(15^{\text {th }}\right.$ ed, Lexis Nexis, Wellington, 2011) The Laws of New Zealand (Butterworths, Wellington, 2001) Stephen Todd The Law of Torts in New Zealand ( $5^{\text {th }}$ ed, Brookers, Wellington, 2009) 


\section{Internet articles}

Cord Jefferson (6 July, 2010) "What if I don't want to be a daddy?" <www.theroot.com>

"Husband discovered he was a father of two after estranged wife forged his signature in IVF deception" (3 march, 2008) London Evening Standard <www.standard.co.uk> Liz Jones "The Craving for a baby that drives women to the ultimate deception" (11 November 2011) <www.dailymail.co.uk>

Nick Craven "Husband tricked into believing wife's children were his own awarded $25 \mathrm{~K}$ - for 'bereavement'" (12 January 2013) <www.dailymail.co.uk>

Nancy Gibbs “A man's right to choose?” (15 March 2006) <www.time.com>

"US Men challenge child support laws" (9 March 2006) <www.bbc.co.uk>

Ministry of Justice "Family Court Review" < www.justice.govt.nz> 